\title{
ETNOGRAFIA DE RUA EM ZAANDAM E AMSTERDÃ (HOLANDA): UM PERCURSO ANTROPOLÓGICO SOBRE RESÍDUOS SÓLIDOS
}

\author{
Carmen Silvia Rial ${ }^{1}$ \\ Cornelia Eckert $^{2}$
}

\section{Lucky accident}

Zaandam, Amsterdã Norte, Holanda

Diário de campo de Carmen Rial, 01 setembro 2019:

Qual a probabilidade de que, na primeira saída de campo em Zaandam, uma pequena cidade na Holanda, para estudar os resíduos sólidos, encontrássemos o supervisor dos lixeiros, Spencer, recolhendo lixo na rua principal, e que ele se deixasse fotografar e entrevistar sem constrangimento? E qual a probabilidade de que Spencer falasse português, por ter sido casado com uma brasileira, ter um filho brasileiro e morado cinco anos em Belém? A probabilidade é muito pequena. Só mesmo um lucky accident, diria Margaret Mead.

Sem dúvida, iniciamos o trabalho de campo em Zaandam com muita, muita sorte, e foi com os olhos arregalados que escutei a história desse improvável encontro, quando Cornelia retornou ao nosso quarto de hotel. Ela foi a responsável por essa primeira incursão, filmadora à mão. Spencer foi um de nossos principais interlocutores na cidade.

Durante 12 dias, desenvolvemos uma experiência em contexto urbano holandês sobre política ambiental voltada para as práticas relacionadas ao desencarte e ao tratamento dos resíduos sólidos junto à população local. Vamos introduzir o problema de pesquisa.

\section{O lixo na perspectiva de um projeto antropológico}

Nossa pesquisa tem por tema principal uma determinação social ordinária na vida cotidiana: o que fazemos com o nosso lixo? Como as prefeituras e o Estado tratam do lixo? Que dispositivos técnicos são politicamente encaminhados nas gestões que se sucedem para o tratamento dos resíduos sólidos? Essas são questões articuladas com conceitos propostos, em 2017, pela European Commission como o de Economia Circular, discutido em diferentes teorias que geram controvérsias e debates.

Mas, por que pesquisar o lixo no Brasil e na Holanda? Estes estudos comparativos/relacionais nascem do amparo à pesquisa bilateral, agenciados por

\footnotetext{
${ }^{1}$ Universidade Federal de Santa Catarina, Brasil. Email: rial@cfh.ufsc.br ORCID id: https://orcid.org/0000-0001-7478-0917

${ }^{2}$ Universidade Federal do Rio Grande do Sul, Brasil. Email: chicaeckert@gmail.com ORCID id: https://orcid.org/0000-0003-1039-2872
} 
instituições de financiamento, como é o caso da CAPES no Brasil. Como consta no projeto original, as missões de estudo na Holanda e no Brasil concentram-se no tema/política Agenda marrom, focando as relações entre renda, poluição e comportamento ambiental que envolvem reciclagem e reaproveitamento do lixo. Os pesquisadores brasileiros implicados desenvolvem suas pesquisas nesta perspectiva bilateral, propondo projetos de pesquisa etnográfica no Brasil e na Holanda. Já a equipe de especialistas holandeses estende seus estudos para regiões na Ásia, como na Indonésia, sob a coordenação de Freek Colombijn (VU, Amsterdam). Esta oportunidade permitiu-nos observar e refletir sobre um contexto vivido e sua política de gestão do lixo, que objetivamos aqui relatar.

\section{Etnografia de rua}

A decisão de elaborar um projeto de pesquisa na Holanda, com base na Etnografia de Rua, para tratar da coleta de resíduos sólidos, segue uma experiência consolidada nos núcleos de pesquisa que coordenamos. ${ }^{3}$ Em Porto Alegre, por exemplo, os núcleos de pesquisa desenvolvem etnografias de rua em equipe desde 1997, experiências de pesquisa que resultaram em vídeos etnográficos, exposições etnofotográficas, produções sonoras, catálogo de exposições, artigos e livro e, sobretudo, divulgação de coleções etnográficas em sistema web (Rocha e Eckert, 2016). Importante destacar a experiência destes núcleos de pesquisa em bairros industriais ou operários, que conheceram fortes reformas urbanas ou projetos de revitalização, em que as etnografias de rua e a produção de imagens revelam as transformações desiguais e assimétricas no contexto, com territórios ora submetidos à intensa reforma urbana e especulação imobiliária, ora em estado vetusto, com acúmulo de lixo e degradados. (Eckert e Rocha, 2016; Eckert et al., 2018). E esse é o motivo pelo qual, também na Holanda, interessava considerar um contexto de bairro com antiga vocação operária, que conhecera uma política de revitalização. Em tal ambiente urbano fundacional,

\footnotetext{
${ }^{3}$ Carmen Rial, coordenadora do Núcleo de Antropologia Visual na UFSC, acumula uma espessa trajetória de formação e produção em Antropologia Visual e de pesquisa sobre o tema ambiental. Neste projeto, especificamente, orienta estudos sobre coleta e reciclagem do lixo, como aprofunda a pesquisa sobre consumidores de resíduos sólidos reciclados, relacionando a estas ações uma reflexão sobre o ethos ecologista (Rial, 2016: 127-158)

Cornelia Eckert, coordenadora do Núcleo de Antropologia Visual e do projeto Banco de Imagens e Efeitos Visuais junto com a antropóloga Ana Luiza Carvalho da Rocha. Em sua formação acadêmica, sempre desenvolveu e orientou pesquisas etnográficas em bairros de vocação operária como, mais recentemente, o estudo no Quarto Distrito, em Porto Alegre (Eckert e Rocha, 2016: 95-122).
} 
interessava conhecer as técnicas de coleta e reciclagem do lixo vinculados a este cenário.

\section{Uma dupla na Holanda - Por que Zaandam?}

A escolha das características da territorialidade a ser pesquisada seguia as intencionalidades do projeto elaborado. Certamente a longa experiência anterior de pesquisa em Amsterdã, por parte de Carmen Rial, foi fundamental nas opções que se construíam. Antecedendo à viagem, realizamos reuniões em Porto Alegre e em Florianópolis. Em uma dessas ocasiões, participou a pesquisadora Carla Pires Vieira da Rocha, que havia desenvolvido período de bolsa sanduíche durante seu doutorado em Amsterdã sobre convergências entre alimentação e meio ambiente, a partir das práticas de imigrantes transnacionais (Rocha, 2017). Também as sugestões de Barbara M. Arisi e Margarete Fagundes Nunes, com estágios-trabalho desenvolvidos na Holanda no âmbito deste projeto de intercâmbio, foram consideradas.

Carmen e Cornelia seguiram, igualmente, as sugestões de Freek Colombijn, que acabara de orientar uma dissertação sobre a revitalização de um bairro em Amsterdã Norte, intitulada Constructing a Sustainable Community: The story of De Ceuvel de Vittoria van der Hoeven. Esta sugestão reforçava que, na região norte, teriam mais chances de encontrar bairros com as características que procuravam: ser um bairro com política de revitalização da área industrial desativada.

Para a localização de bairros de origem industrial no norte de Amsterdã, recorremos à busca pelo Google Maps. Após esta demarcação, a procura por habitação, dentro de suas possibilidades financeiras, também foi fator determinante. Recorreram a sites de buscas como Airbnb, com suas inúmeras ofertas de moradia.

Concentram-se na grande Amsterdam-Noord, por seu longo histórico de produção industrial e centralização de famílias operárias, apresentando políticas de revitalização. Mais uma vez, por um lucky accident, o dispositivo de busca por hospedagem mais barata levou-as a Zaandam ou, mais precisamente, ao bairro de Russischebuurt. Pelo buscador, localizaram um hotel recém-inaugurado, o Easy Hotel Amsterdam Zaandam, a preço razoável, fator decisivo para que optassem por esse lugar. E assim chegaram à cidade de Zaandam, do município Zaanstad, na região metropolitana de Amsterdã, que também foi contexto de seus exercícios etnográficos. 


\section{A entrada no campo, por Amsterdã}

Final de agosto, 2019, Carmen e Cornelia desembarcaram em Amsterdã, que as recebe com um forte calor. Em seu primeiro dia, dedicaram-se ao seu deslocamento pelas ruas centrais. Conhecida por seus mais de $100 \mathrm{Km}$ de canais e pelas 1500 pontes, a fama da relação da cidade com a água seja para transporte, seja para consumo, é bem propalada. Sim, é também conhecida pelo comércio, pelas bicicletas, pelo Red Lights District (um antigo bairro de prostituição), pelo consumo de drogas, pelos queijos, chocolates e por outros atrativos que encantam milhares de turistas todos os anos.

Em Amsterdã, concentraram seu deslocamento nas ruas centrais, acompanhando os canais, observando e fotografando, desde então, as latas de lixo, e tentando decifrar as regras locais de coleta desse material.

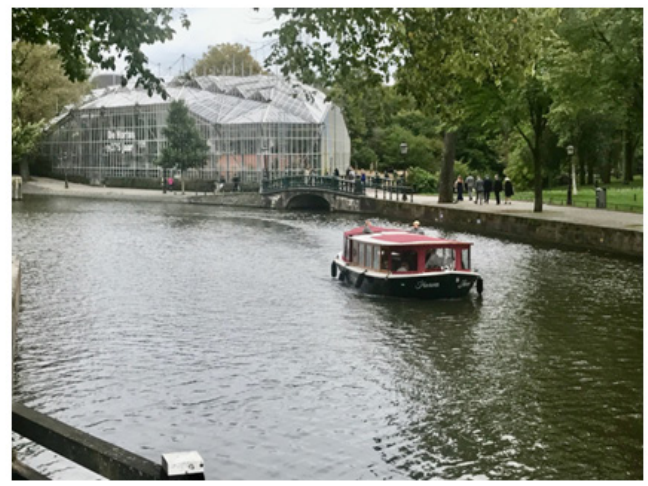

1

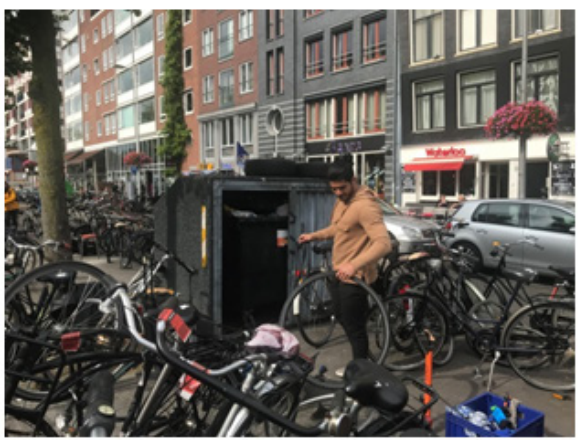

3

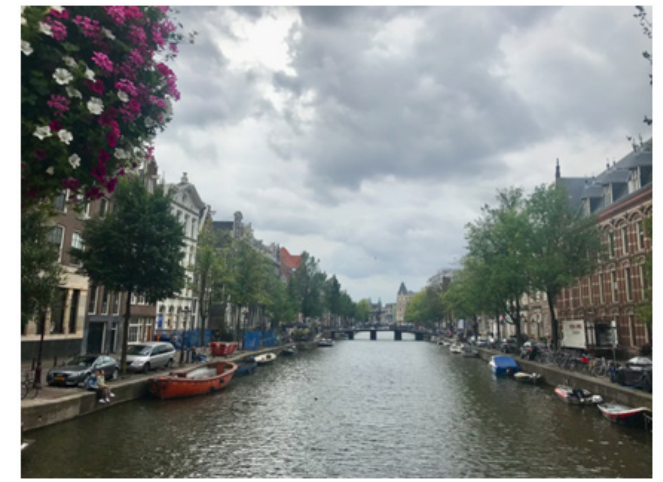

2

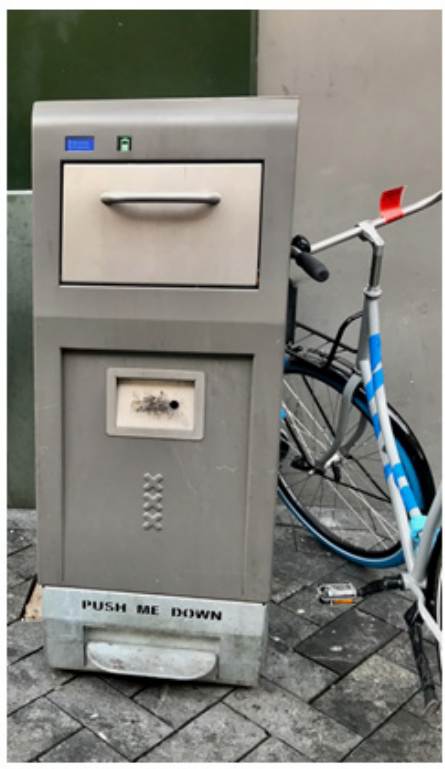

4 
Foto 1 - Vista do canal. Amsterdã, Holanda, agosto 2019. Foto de Cornelia Eckert Foto 2 - Vista do canal. Amsterdã, Holanda, agosto 2019. Foto de Cornelia Eckert Foto 3 - A cidade das bicicletas. Amsterdã, Holanda, agosto 2019. Foto de Cornelia Eckert Foto 4 - Lixeira. Amsterdã, Holanda, agosto 2019. Foto de Cornelia Eckert

Logo se depararam com uma cena que, para elas, era um imponderável da vida cotidiana, mas que, para os moradores, certamente uma cena comum. Observando o movimento no canal, viram que um dos barcos transportava crianças portando coletes salva-vidas e que cada uma segurava um coletor na mão (rede ou coador), com o qual "pescavam" o lixo que boiava no canal. Estavam acompanhadas de dois adultos com coletes de orientadores. A inscrição na embarcação anunciava tratar-se da instituição Plastic Whale. Não havia muitos rejeitos à primeira vista, mas aqui e lá alguma garrafa, lata, saco e copos de plástico eram coletados pelos pescadores mirins de resíduos sólidos. No site da empresa, encontramos a seguinte elucidação:

Plastic Whale is a social enterprise with a mission - we want plastic-free waters. Worldwide. We achieve this by showing others that economic value can be created from plastic waste, involving as many people and businesses as possible within the pillars: We Collect, We Create, We Educate. https://plasticwhale.com/ Consulta em 23 de agosto 2019.

Só esta ação já merecia uma pesquisa. Não somente crianças e moradores participam do programa, também turistas podem se inscrever nesta atividade e, literalmente, coletar lixo nos canais. Esta empresa também oferece workshops de reciclagem e de construção de materiais com os objetos recolhidos.

Ainda em Amsterdã, na fase de descoberta do universo de pesquisa, destacamos a visita ao Museu da Cidade, com a intenção de coletar dados históricos deste lugar no contexto dos países baixos. 


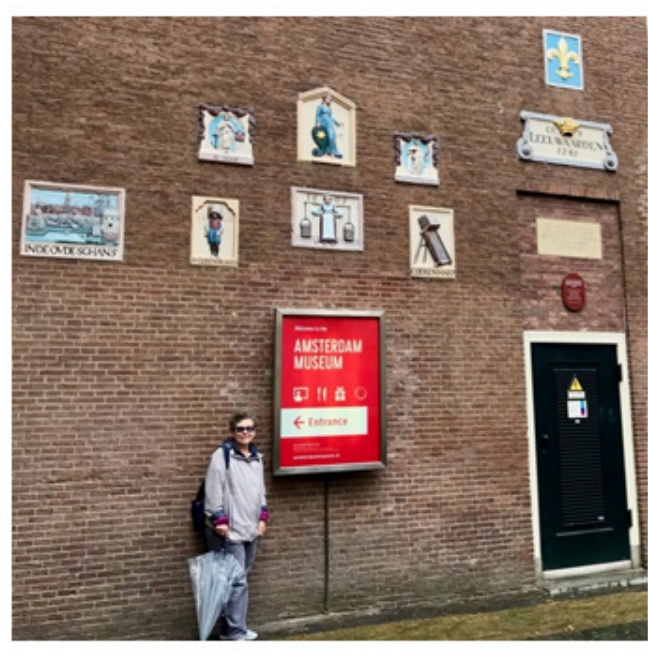

5

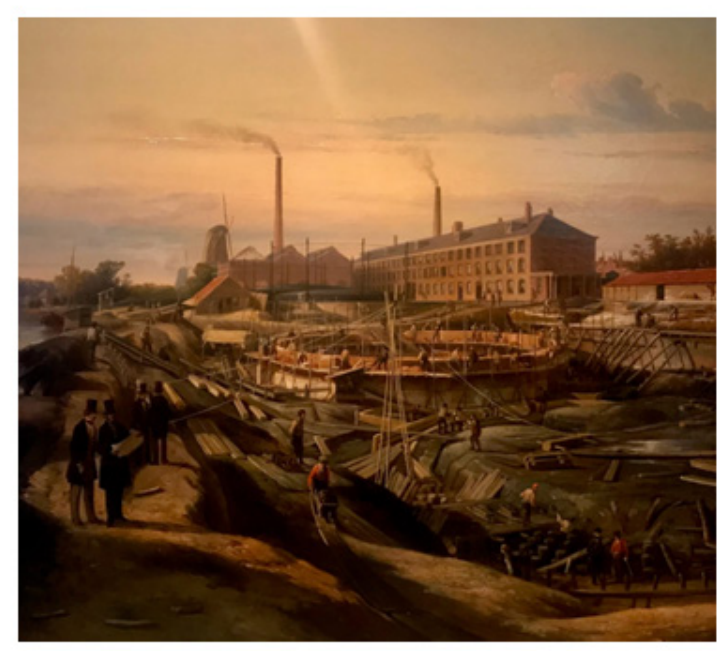

6

Foto 5 - Entrada do Museu da Cidade. Amsterdã, Holanda, 1 de setembro 2019. Foto de Carmen Rial. Foto 6 - The construction of Two Gasholders at Hollandsche Gazfabriek on Weteringschans, 1847. Pintor Cornelis Springer (1817-1891). Acervo Museu da Cidade. Amsterdã, Holanda, 1 de setembro 2019. Foto de Cornelia Eckert

O museu mostra elementos pré-históricos e destaca a construção dos diques no século XII, período em que a cidade de pescadores começa a despontar como porto comercial. Com vários painéis interativos, o visitante descobre as informações sobre o período do domínio espanhol e, mais tarde, francês. O porto e a construção de diques têm destaque especial por seu valor econômico e comercial em todas as conjunturas históricas da cidade. Finalmente, os contextos de guerra, de resistência e os movimentos sociais contemporâneos, como o primeiro casamento gay. A presença de artistas e de intelectuais de renome recebe uma galeria especial, além de mapas projetados em vitrines nas paredes e no chão, permitindo uma interação diferenciada com a linha de tempo.

\section{Chegando a Zaandam}

O deslocamento de Amsterdã para Zaandam foi de trem. Na enorme estação central em Amsterdã, elas compraram as passagens em uma máquina automática e monitoramos o horário e a plataforma de embarque pelos enormes placares. Carregadas com malas e mochilas contendo nossos computadores, encararam as escadas. Na paisagem, logo se destacam aglomerados de casas, algumas zonas de cultivo, mas, de modo geral, o ambiente é predominantemente industrial, como comprovam as instalações gigantescas com torres expelindo fumaça. 
$\mathrm{Na}$ chegada à estação Zaandam, encontraram um local em reformas. Vislumbraram, entre os materiais de edificação, um elevador, facilitando-lhes o carregamento das malas. Poucos passos no lado externo e logo avistaram o que constava na internet, uma construção inusitada: um prédio com um amontoado de 70 casas típicas com colorido diverso. Primeiramente, pensaram ser um museu, mais tarde entenderam que se tratava de um hotel. Percorreram alguns metros em uma espécie de rampa contínua, já que, por baixo, havia um canal, calçadas e ruas.

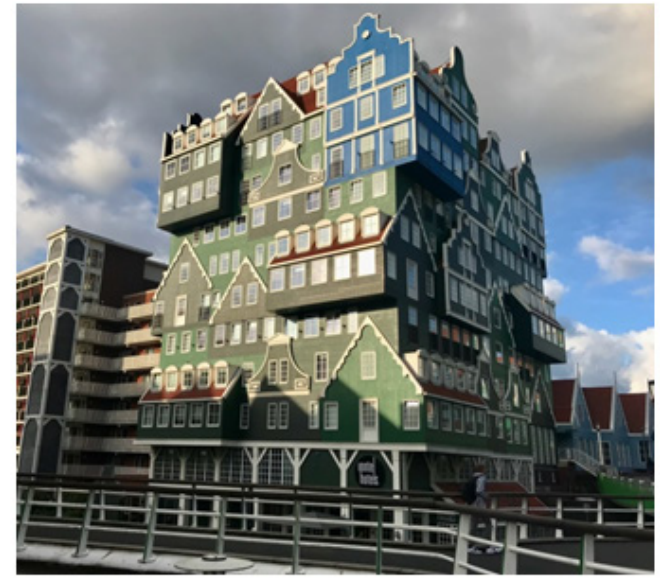

7

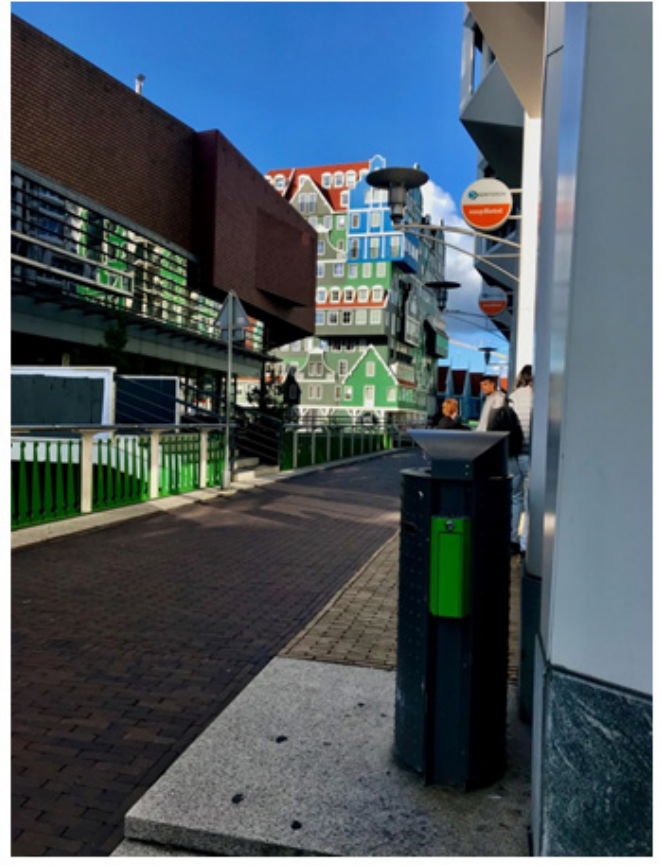

8

Foto 7 - Inntel hotel, simulacro de casas típicas. Amsterdã, Holanda, 2 de setembro 2019. Foto de Cornelia Eckert.

Foto 8 - Inntel hotel visto a partir do Easy hotel. Amsterdã, Holanda, 2 de setembro 2019. Foto de Cornelia Eckert.

No percurso pela rampa, passaram pela prefeitura, toda estilizada com uma arquitetura imitando madeira talhada à moda antiga. Sobre este prédio, voltarão por ocasião das visitas que ali realizaram.

Zaandam, onde iriam temporariamente morar, é a principal cidade do município de Zaanstad. Os direitos de cidade datam de 1811. Banhada pelo rio Zaan, contava em 2017 com uma população de 76.804 h (Site da prefeitura).

Já exaustas e molhadas pela chuva, chegaram ao hotel Easy, próximo da prefeitura, com acesso pela rampa, uma rua numa espécie de mezanino. Poucos metros depois, a rampa finalizava com uma grande escadaria que dava passagem à principal 
"rua" comercial da cidade. Na realidade, um canal rodeado de calçadas, podendo ser acessada apenas por pedestres, bicicletas ou pequenos carros de entrega e de limpeza.

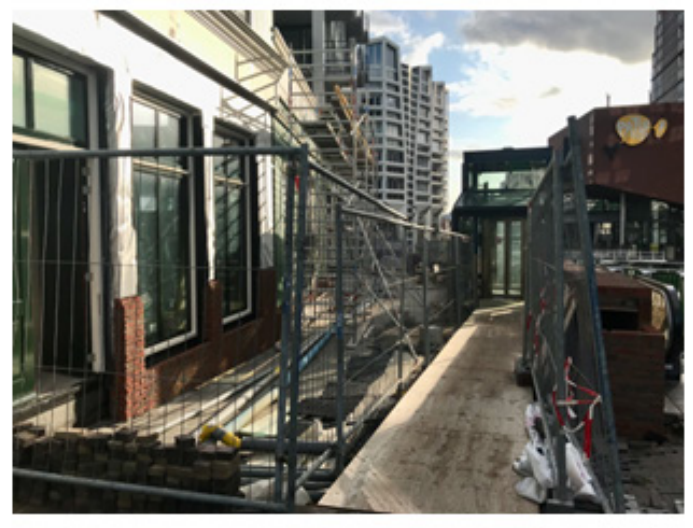

9

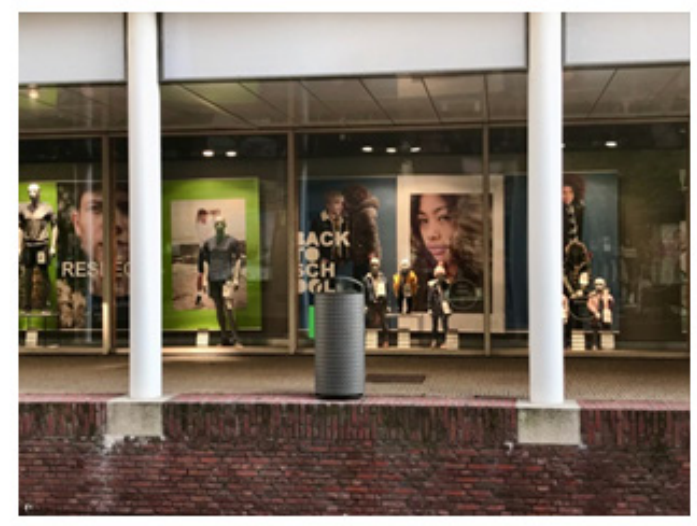

10

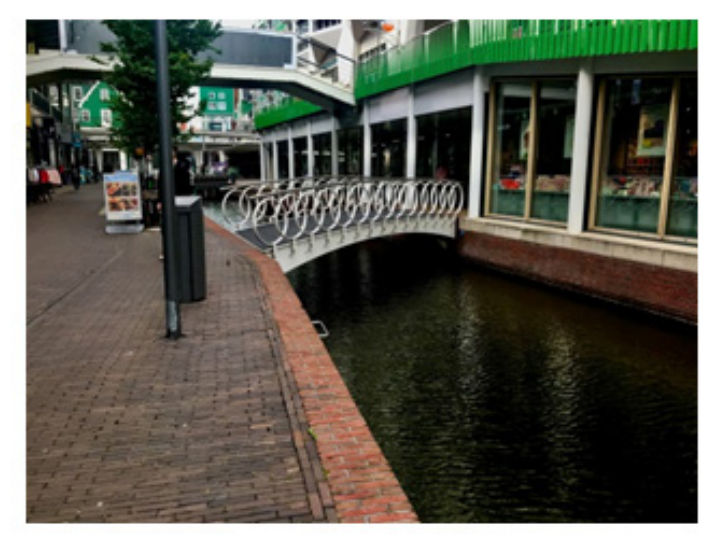

11

Foto 9 - Saída da estação de trem em reformas. Zaandam, Holanda, 2 de setembro 2019. Foto de Cornelia Eckert

Foto 10 - Calçada próxima ao hotel Easy. Zaandam, Holanda, 2 de setembro 2019. Foto de Cornelia Eckert

Foto 11 - Rua Rustenburg. Zaandam, Holanda, 3 de setembro 2019. Foto de Carmen Rial.

\section{Os primeiros sinais de uma política de coleta de resíduos}

A primeira saída de casa para buscaram algo para comer e procurar um supermercado foi o indício de que, de fato, estavam em um contexto com acentuada paisagem revitalizada com reformas provavelmente recentes, um lugar marcado por comodidades de acessibilidade, em face das inúmeras pontes e escadarias. Em poucos passos, entraram uma escada rolante ou elevadores para chegar à rua inferior. Na rua superior ou na rua inferior, casas comerciais conhecidas no mundo global da alimentação ou do consumo de produtos diversos.

Conforme as anotações no diário, cedo, no dia 02 de setembro: 
Após uma chegada com chuva, o dia ensolarado convidava para a observação da rotina nas ruas do bairro. Próximo ao hotel, as ruas em torno de um canal são convidativas para uma caminhada com câmera na mão. Entramos no supermercado, onde fomos tomar um café da manhã, já que o hotel não oferecia este serviço e no supermercado era de graça. O super ficava em frente ao hotel. A primeira foto foi do maquinário de coleta de resíduos sólidos. Mas precisávamos também de uma chaleira elétrica. Ao lado do supermercado, encontramos uma grande loja de produtos elétricos e eletrônicos e mais um sistema de coleta de lixo instalado na entrada do prédio. Tiramos fotos desse sistema seletivo no interior da loja Medla e na parte externa. (Diário de Cornelia Eckert).

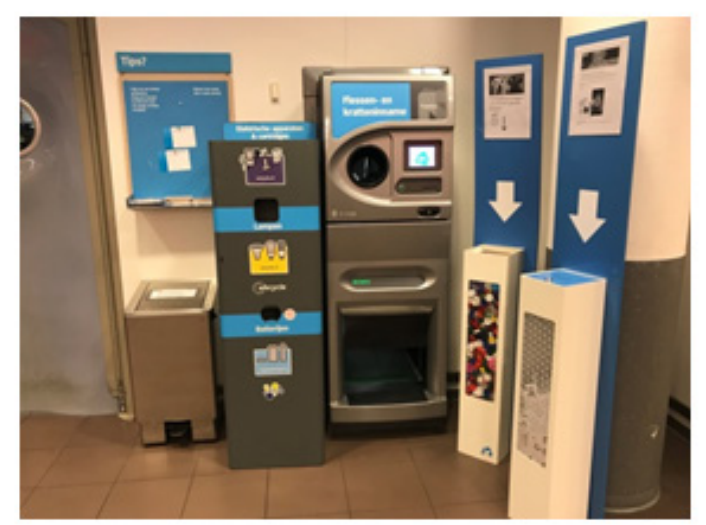

12

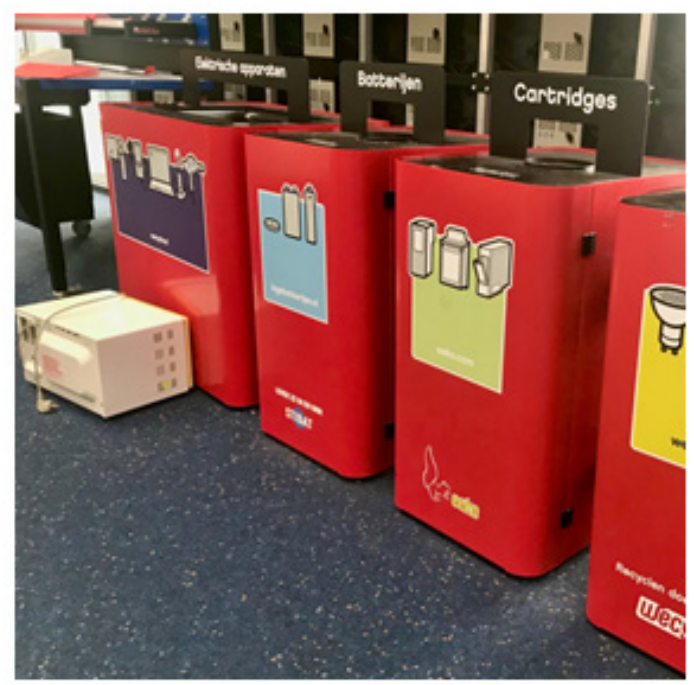

14

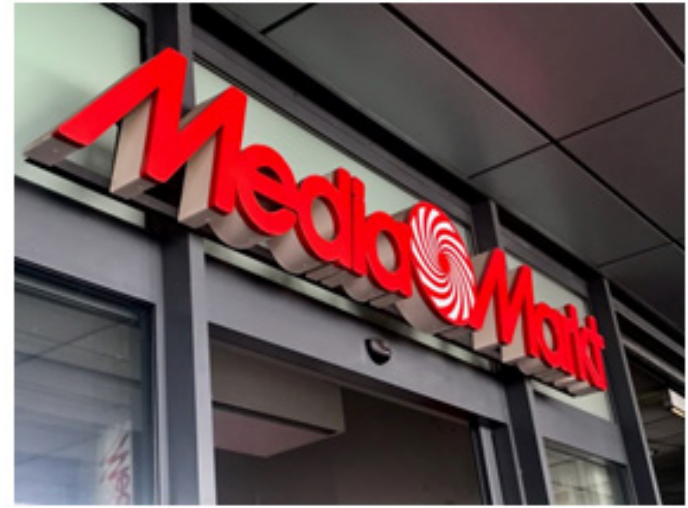

13

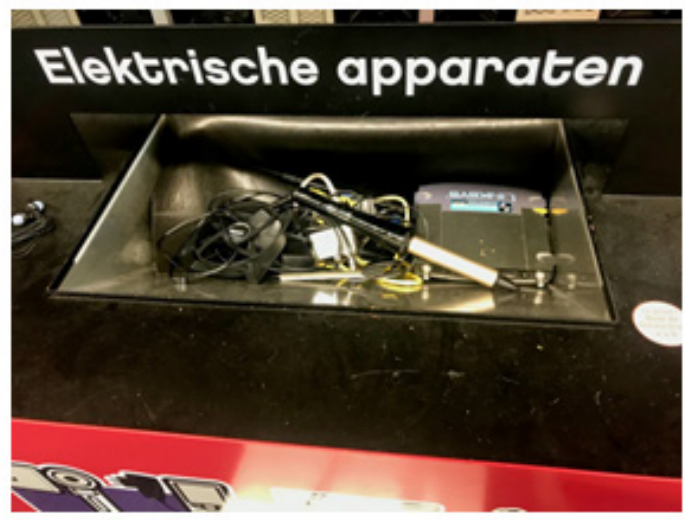

15 


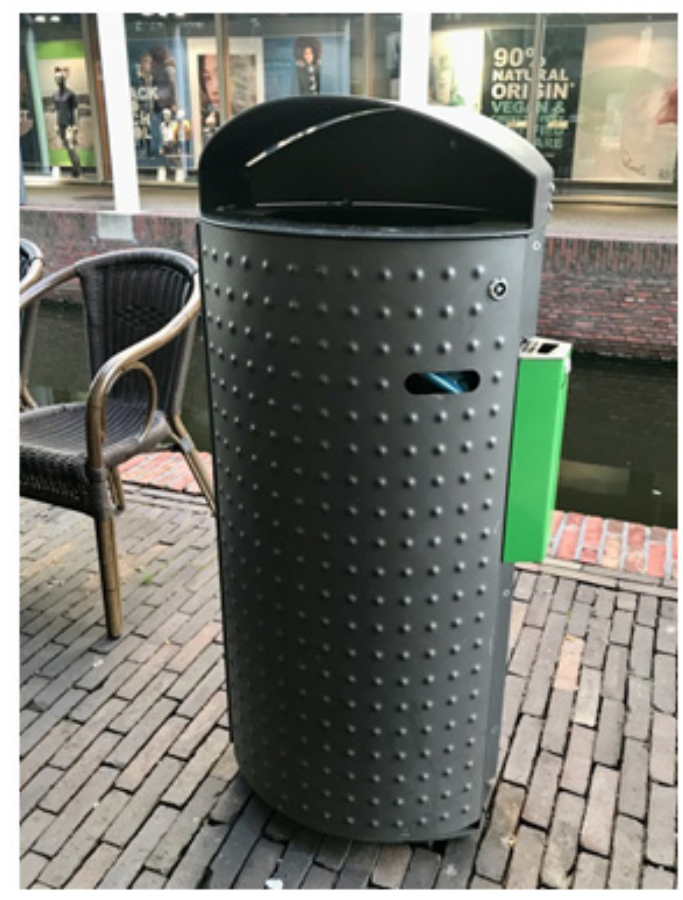

16

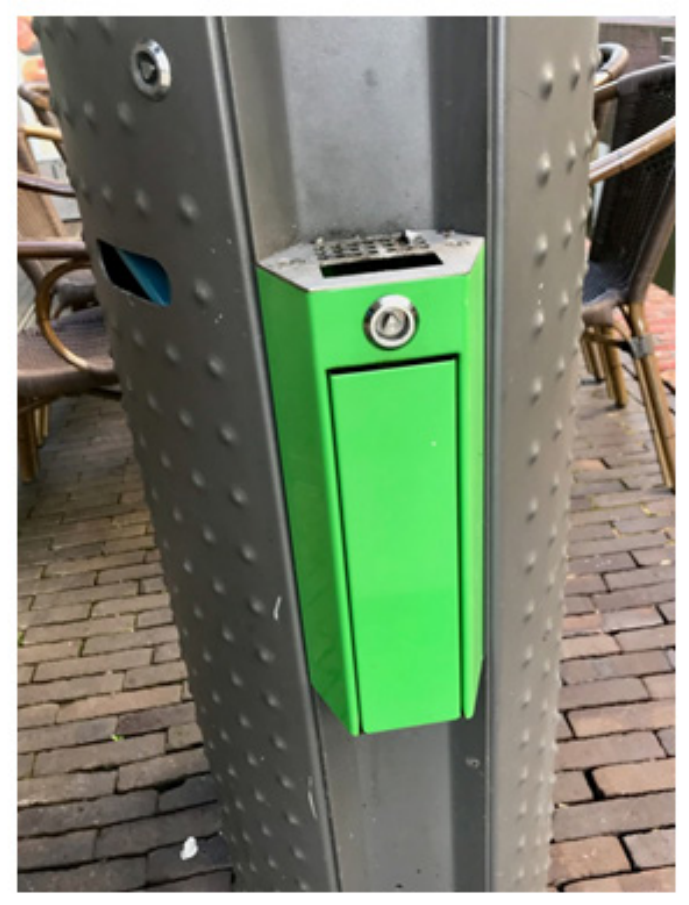

17

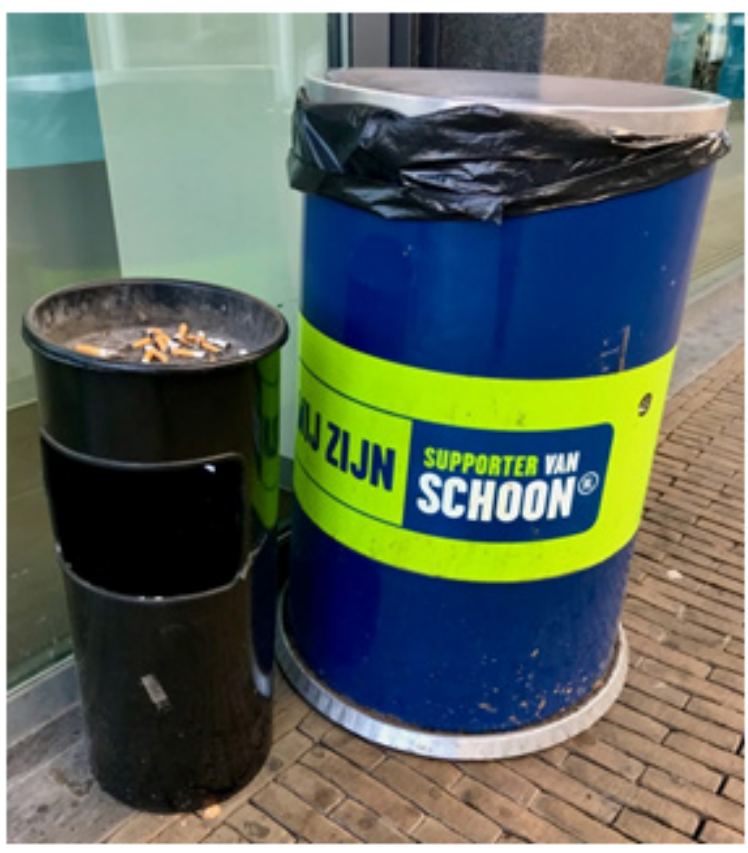

18

Foto 12 - Entrada do supermercado. Zaandam, Holanda, 3 de setembro 2019. Foto de Carmen Rial. Foto 13 - Entrada da loja Medla. Zaandam, Holanda, 3 de setembro 2019. Foto de Cornelia Eckert Foto 14 - Coletores de resíduos. Zaandam, Holanda, 3 de setembro 2019. Foto de Cornelia Eckert Foto 15 - Coletor de resíduo eletrônico. Zaandam, Holanda, 3 de setembro 2019. Foto de Cornelia Eckert Foto 16 - Lixeiras na calçada. Zaandam, Holanda, 3 de setembro 2019. Foto de Cornelia Eckert Foto 17 - idem Foto 18 - idem 
Os coletores de lixo chamam a atenção por apresentarem diferentes containers para o recolhimento seletivo de resíduos. $\mathrm{Na}$ rua, muitas latas coletoras de lixo com dispositivo anexado, próprio para apagar o cigarro e para receber as bitucas ou guimbas. Isto não quer dizer que não raro tenhamos visto os restos de cigarro jogados no chão sendo recolhidos por funcionários da prefeitura (coletores de lixos).

A caminhada pelas ruas que circundam o canal, uma espécie de calçadão, permite observar o tipo de comércio presente, típico de camadas médias, com marcas globais como a C\&A, o cinema Pathé, Cafés franceses, etc. Mas o que mais chama a atenção é a bela paisagem que se avista: o canal cercado de gramado, com presença de pássaros, árvores, cabanas com vendas de alimentação ou outros produtos típicos e uma larga calçada para o deslocamento do pedestre. Nos bancos e muretas, muitos estão sentados para aproveitar o sol e, em geral, alimentando-se. (Diário de Cornelia Eckert).

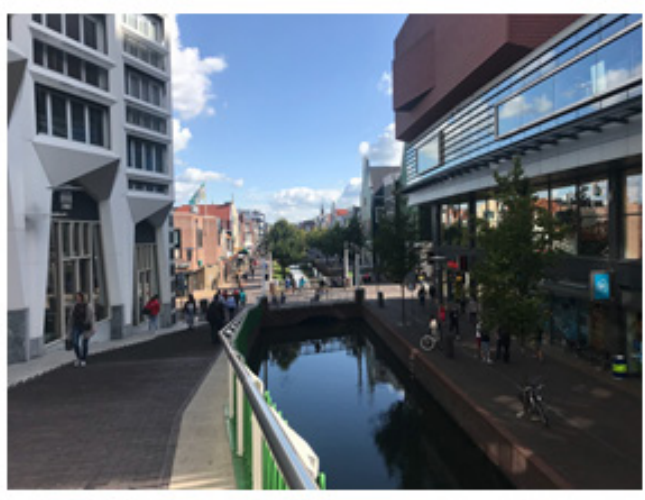

19

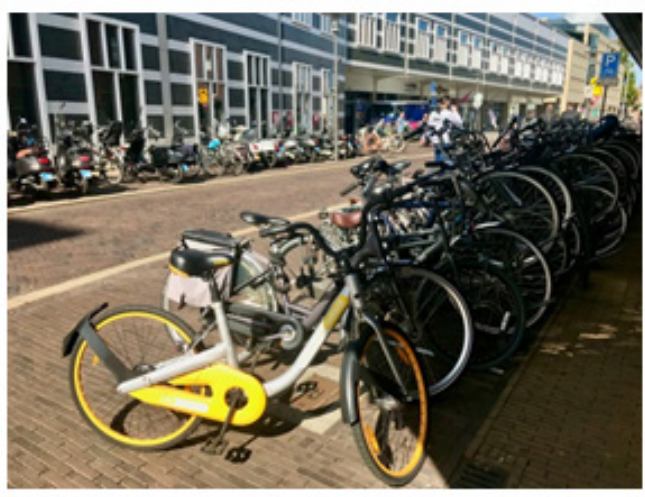

20

Foto 19 - Rampa de acesso ao centro e calçadão que circunda o canal Gedempte Gracht. Zaandam, Holanda, 3 de setembro 2019. Foto de Cornelia Eckert

Foto 20 -Rua Rustenburg. Zaandam, Holanda, 3 de setembro 2019. Foto de Cornelia Eckert

\section{Um encontro inusitado}

O segundo dia em Zaandam implicava um mergulho intensivo no campo, ainda desconhecido. No primeiro instante, Carmen Rial, atarefada com a urgência de pareceres para uma fundação financeira norte-americana, permaneceu trabalhando no hotel, e Cornelia Eckert aventurou-se ao processo de familiarização do contexto. Com a presença rara do sol, a caminhada foi concentrada na longa rua principal, Gedempte Gracht, uma primeira investida de Etnografia de Rua com câmera na mão.

Dado o passeio solitário, trazemos o relato do Diário de campo de Cornelia: 
Comecei a caminhar, já tomando algumas imagens, com a intenção de captar a bela paisagem, agradável ao olhar da antropóloga-turista. Fiz uma panorâmica. Logo percebi que estava, já de longe, fotografando a ação de um gari realizando a limpeza da via pública e trocando o saco de um lixo coletor.

Aproximei-me, sempre fotografando, evitando captar seu rosto. Iniciei uma conversação perguntando sobre que tarefa ele estava realizando. Ele explicou que estava trocando o plástico maior azul e reabastecendo um kit higiênico com pequenos sacos de plástico pequenos vermelhos para a coleta de fezes de animais, chamado Belloo.

Perguntei se podia fotografar e filmar. $\mathrm{O}$ gari respondeu que sim, mas que eu não poderia pegar o rosto dele, porque a empresa não permitia. Respondi que tomaria cuidado. Fotografei e filmei o processo de troca de sacos. Depois fotografei o aparato para apagar e coletar bitucas. Pedi para ele me explicar um pouco mais sobre suas tarefas. Dado ao meu forte sotaque, perguntou de onde eu vinha. Respondi que do Brasil e que estava pesquisando sobre coleta de lixos, por isso meu interesse em fotografar. Peguei um saquinho vermelho e o guardei.

O gari sorriu e começou a falar algumas palavras em português. Fiquei muito surpresa e perguntei se ele era brasileiro.

- Não, respondeu, eu sou holandês, mas fui casado com uma brasileira.

- Verdade? Respondi.

- Como você se chama? Perguntou.

- Meu nome é Cornelia.

- Meu nome é Spencer. Muito prazer.

- O prazer é meu, uma surpresa encontrar alguém que conhece o Brasil e fale português em um lugar que acabei de chegar.

E ele seguiu me explicando.

- Eu fui para o Brasil para umas férias, em Belém do Pará. Lá conheci uma moça e nos casamos. Fiquei lá por quatro anos e tivemos um filho. Mas, no fim, quis voltar e ela, não. Nos separamos.

- E teu filho? Perguntei. Está no Brasil?

- Não, respondeu, meu filho mora comigo. Está na escola, no Ensino Médio.

Seguimos conversando sobre seu filho e seus estudos. Mas aproveitei o inusitado do encontro e perguntei sobre sua prática de trabalho. Quais eram as tarefas que estava realizando. Explicou sobre a rotineira troca de sacos, a tarefa de varrer e, sobretudo, de coletar as bitucas, coletar algum lixo no gramado ou na calçada e coletar objetos nas águas do canal com uma rede.

Fiquei observando sua atuação na limpeza do canal e fotografando. $\mathrm{Na}$ sequência, eu fotografei e filmei o equipamento usado, como os sacos plásticos, e perguntei se se tratava de material reciclável. Ele respondeu que sim, que tudo é reciclado, mas que tem o lixo, e este é incinerado. Mostrou como processa a retirada do saco e explicou que o saco menor está disponível para os proprietários de cachorros recolherem as fezes dos animais. O saquinho com as fezes pode ser jogado no lixo maior.

Em seguida, perguntei sobre os locais onde trabalhava e o tempo de suas atividades.

- Trabalho 8 horas diárias, e as atividades se iniciam, pegando a caminhoneta elétrica na garagem para fazer a limpeza dos lixos, da água do canal e das ervas daninhas.

Também aproveitei para perguntar sobre o carrinho. Explicou que era elétrico e que podia andar no calçadão. Ele disse ser o supervisor dos garis daquela região.

Depois, Spencer mostrou que era preciso retirar as ervas daninhas. Também perguntei sobre os cigarros jogados no chão. Spencer disse ser um lixo mais difícil de coletar. Mostrou o equipamento para a coleta de resíduos no chão sem precisar se abaixar. Filmei e fotografei. Spencer sugeriu passar na prefeitura e mostrou onde fica, ao lado da casa verde com o grande relógio. Lá eu conseguiria maiores informações sobre coleta e reciclagem. Expliquei que me interessa visitar o depósito de lixo, mesmo sabendo que o tempo de pesquisa seria curto para tal empreitada. Perguntei se podia encontrá-lo novamente, e ele me disse passar todos os dias por esta região, mais ou menos no mesmo horário. Agradecemos e nos despedimos

Ainda fotografei outros instrumentos e, por fim, nos despedimos.

Ele seguiu na pequena camionete e parava a cada lixo coletor. Eu o seguia ora fotografando, ora observando suas atividades.

Caminhamos até o final do canal que desemboca no rio Zaan. A cidade segue do outro lado de uma ponte levadiça. Assistir sua abertura para a passagem de carros impressionou-nos, 
mas resolvemos deixar o outro lado da cidade para um outro momento. Retornamos pelo outro lado do canal, observando as atividades comerciais oferecidas, os hábitos dos moradores aproveitando a tarde ensolarada e razoavelmente quente, após um dia de chuva e frio. Muitos ocupavam os diferentes espaços oferecidos para sentar-se ou consumir.

Verificamos que o chão tinha muitos restos de cigarros, sobretudo entre os pisos no chão, entre os paralelepípedos, locais de difícil coleta.

Ficamos atentas igualmente aos tipos de latas de lixo. Ao longo do canal, elas seguem um padrão e estão dispostas em grande quantidade, sobretudo próximo às pequenas pontes de passagem de pedestres. Em duas ocasiões, testemunhamos pessoas bebendo em copos de papel ao lado dos coletores. Ao finalizarem seu conteúdo, jogam imediatamente o resíduo no lixo. Tentei fotografar, mas a rapidez dos gestos dificultou-me uma tomada em sequência.

Por um tempo, observamos os passantes nas faixas de segurança. Desta vez, nossa atenção foi para a grande quantidade de bicicletas e como se comportavam no trânsito. De modo geral, não há uso de equipamento para a proteção da cabeça ou braços. Muitos andam em duplas, um ao lado do outro, conversando. Um senhor passou com o pássaro de estimação no seu ombro.

Voltamos a caminhar ao longo do calçadão. Observamos que quase todas as lojas colocam dispositivos de propaganda na calçada, provavelmente permitido, mas, em algumas ocasiões, observo que dificultam a passagem do pedestre.

Também testemunhamos o estacionamento de bicicletas em locais proibidos. Spencer havia me chamado a atenção para o grande uso de bicicletas na cidade e para o fato de como muitos não obedecem às regras de deslocamento e estacionamento. Ele havia me apontado uma bicicleta mal estacionada, mas que não era tarefa dele fiscalizar. Mas que havia policiamento para isto e que a multa era significativa. Respondemos para ele que ainda não havíamos avistado policial algum. Mas eles estão por aí, respondeu ele.

Caminhada realizada, é hora de salvar as fotos no computador, com medo de perder o registro precioso da conversa com Spencer.

No hotel, salvo as fotos e a entrevista no computador e, juntamente com Carmen Rial, organizamos o plano para próxima saída de campo. (Diário de Cornelia Eckert) 


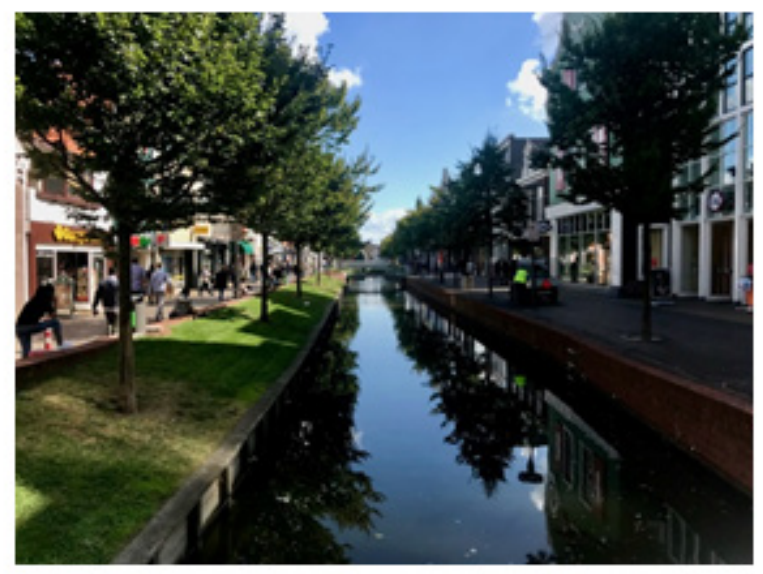

21

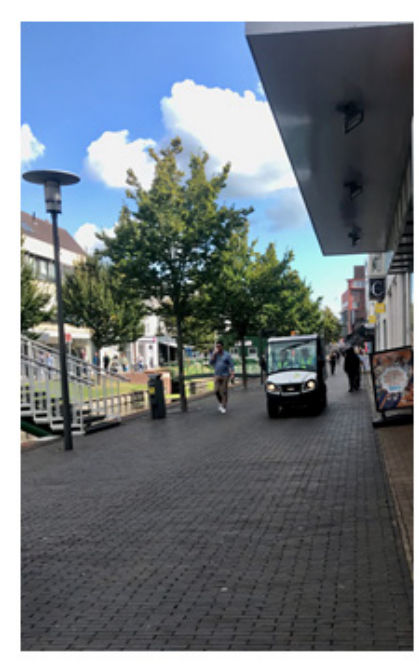

22

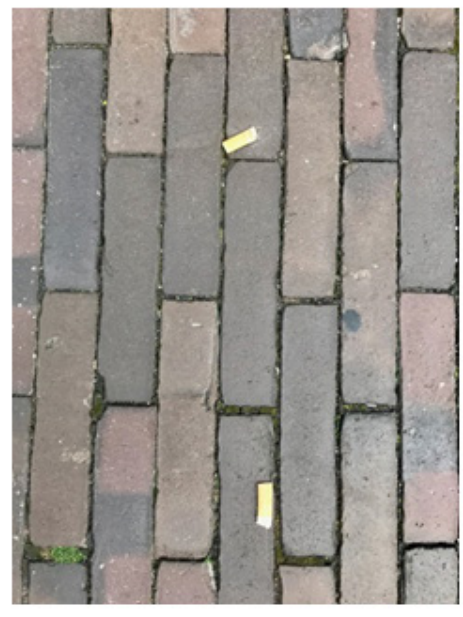

25

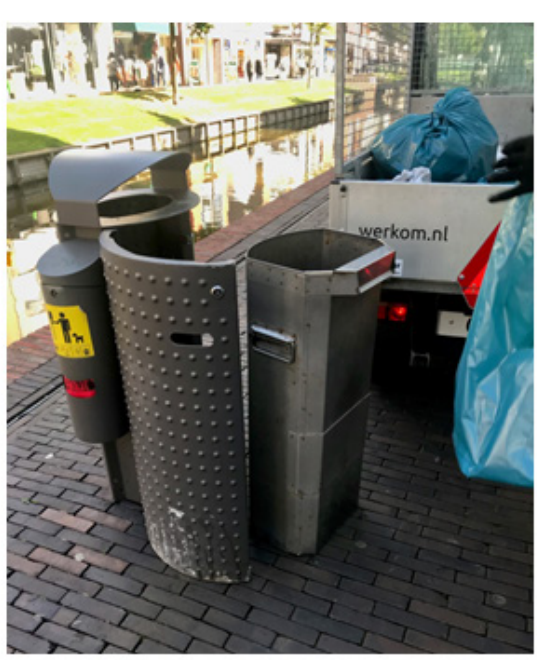

23

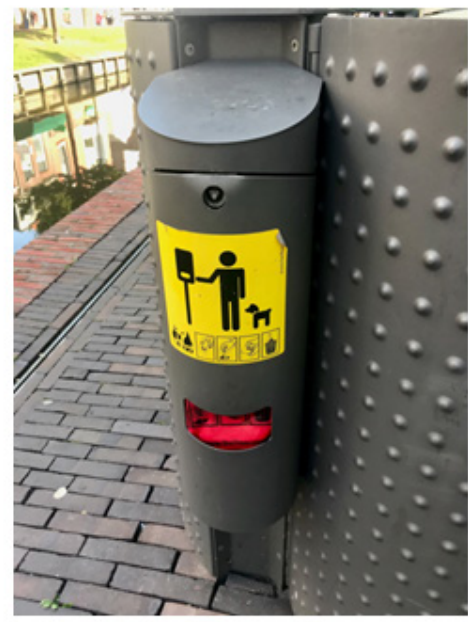

26

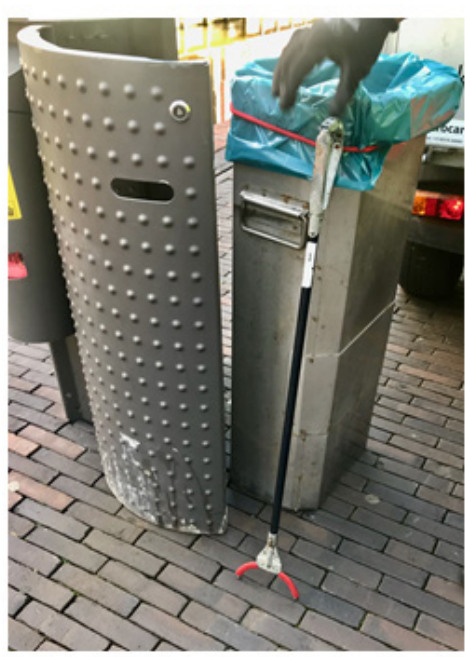

24

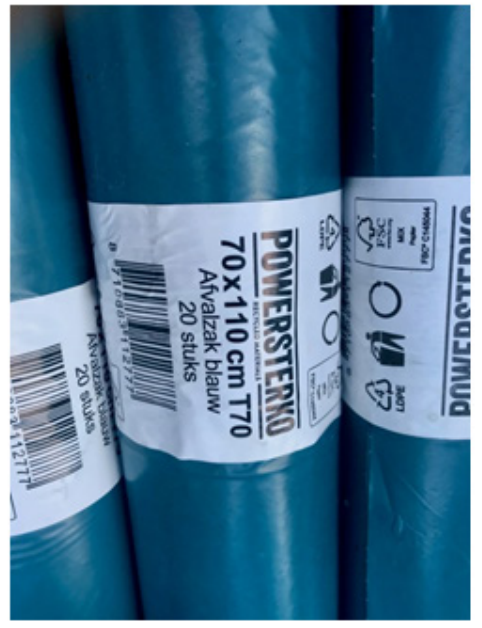

27 


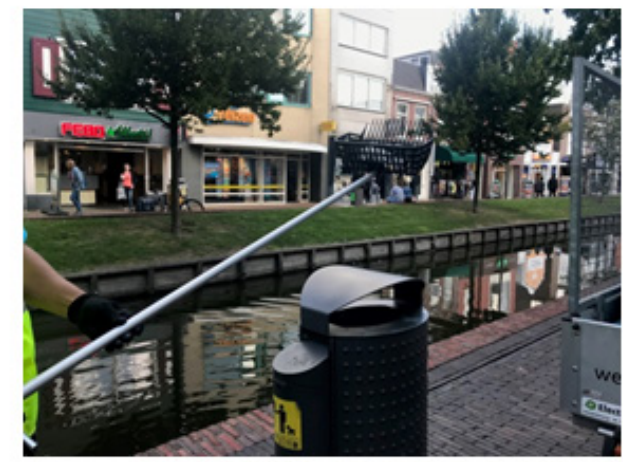

28

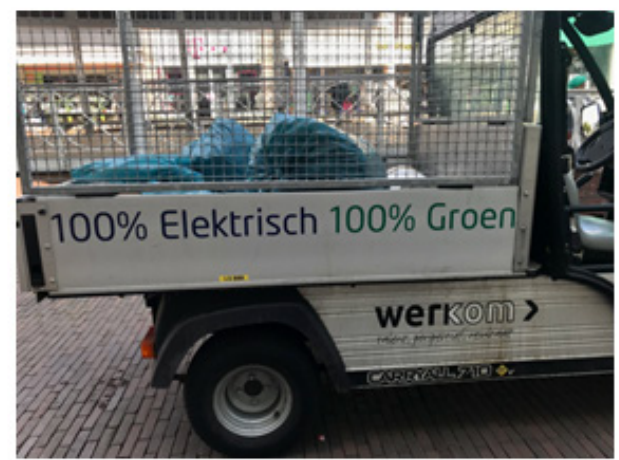

29

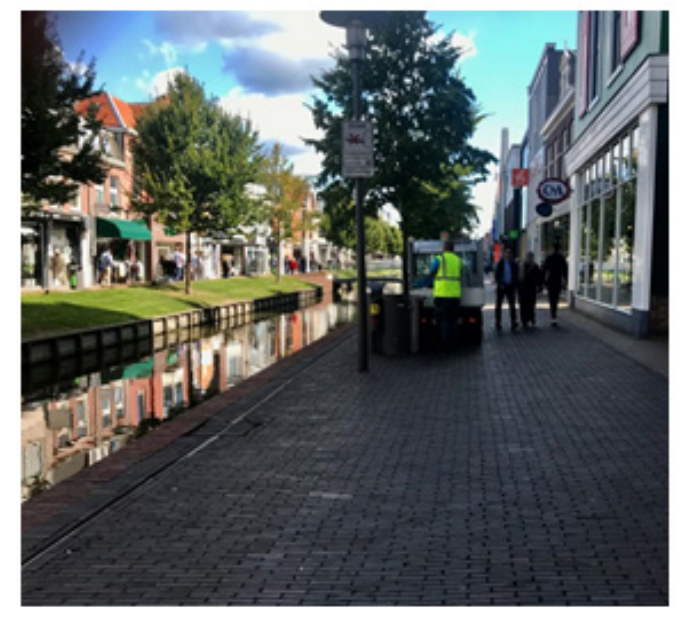

30

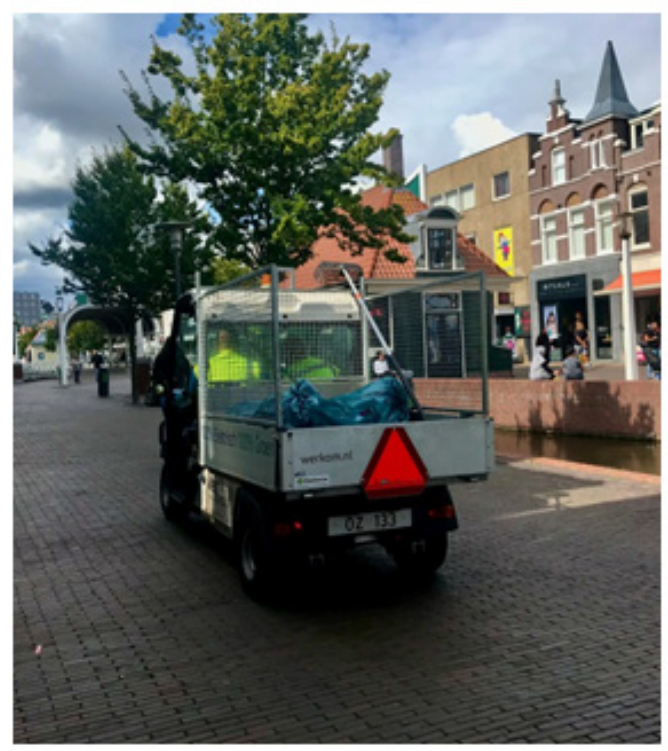

31 


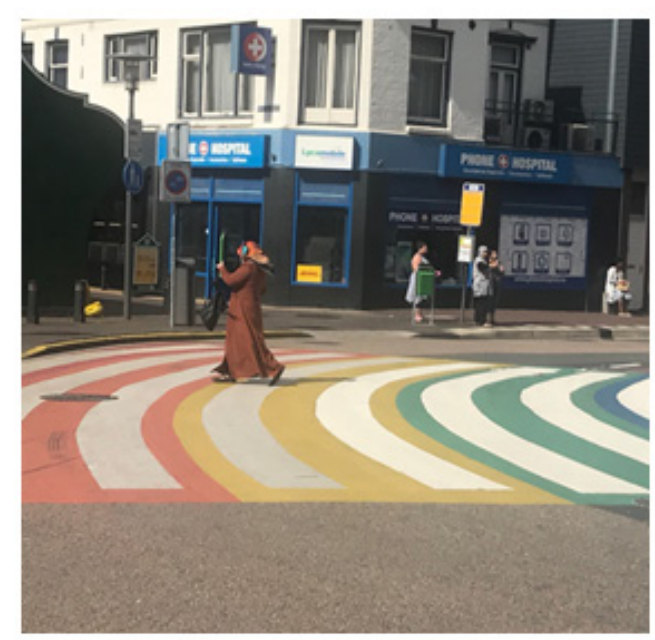

32

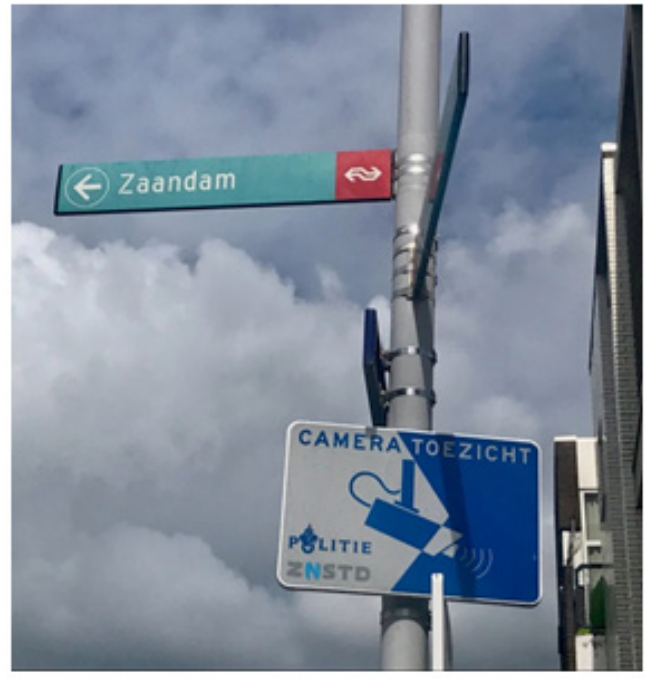

34

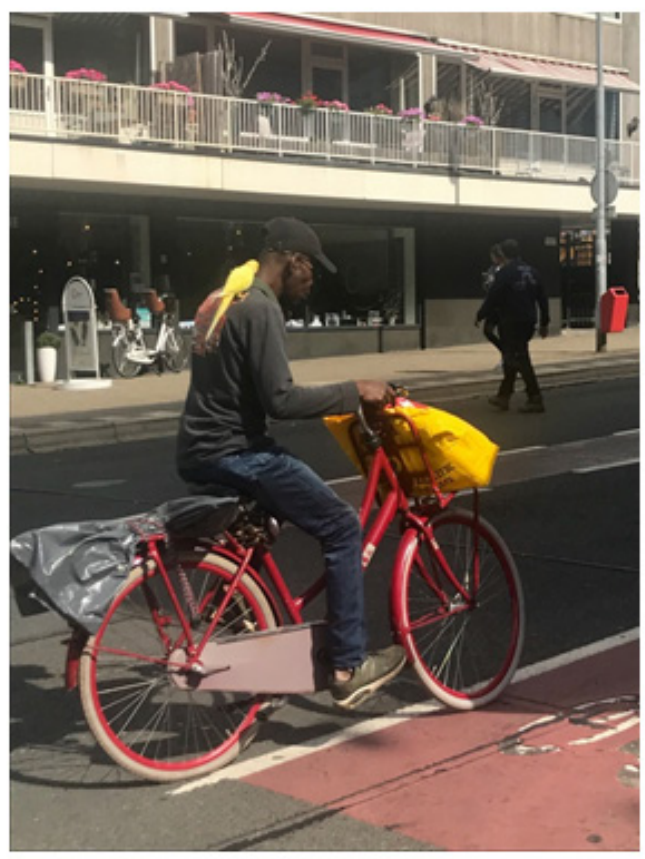

33

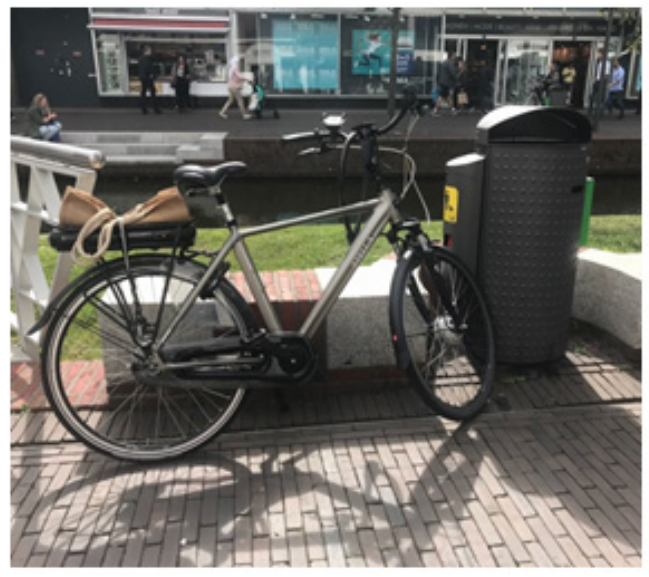

35 


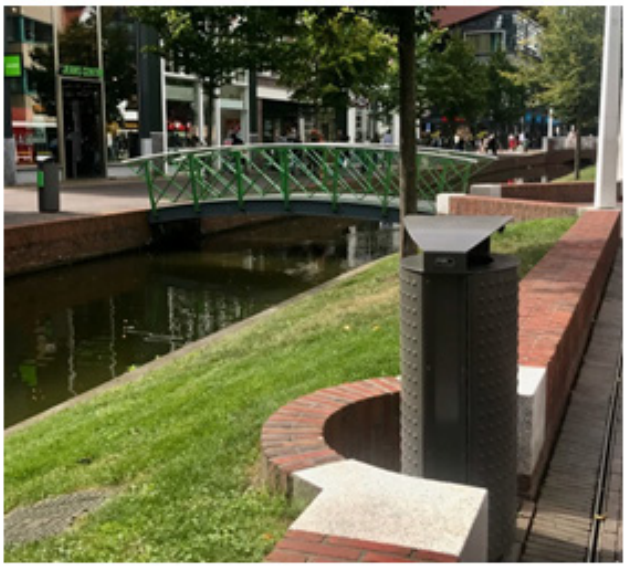

36

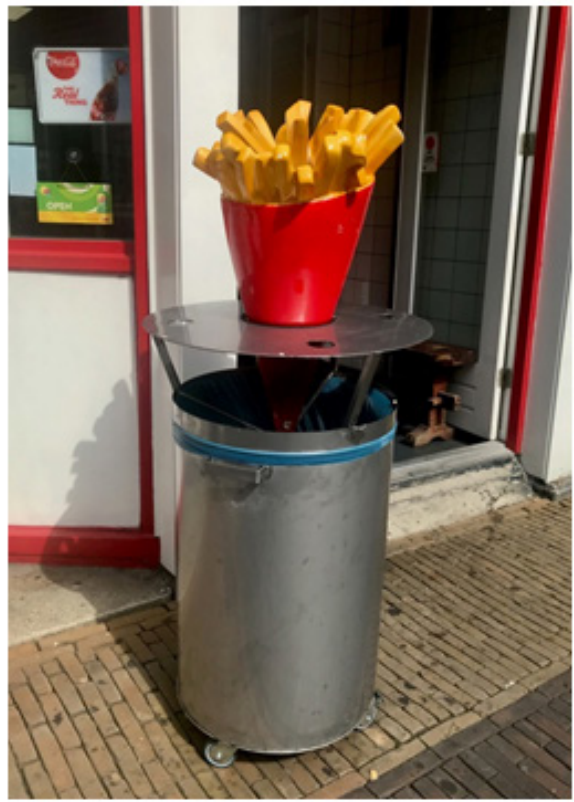

37

Foto 21 - Vista do canal Gedempte Gracht. Zaandam, Holanda. Foto de Cornelia Eckert, 2 de setembro 2019.

Foto 22 - No canal Gedempte Gracht. Vista de um carro elétrico de limpeza urbana. Idem.

Foto 23 - Lixeira da municipalidade sendo limpa por funcionário. Idem

Foto 24 - Coletor de pontas de cigarros (bitucas) mostradas pelo funcionário Spencer. Idem

Foto 25 - Bitucas no chão. Idem

Foto 26 - Porta-sacos de plástico vermelhos para a coleta de fezes de animais. Idem

Foto 27 - Sacos de plástico azuis para a coleta de lixos. Idem

Foto 28 - Coletor de rejeitos presentes na água. Idem

Foto 29 - Carro elétrico da municipalidade para a coleta de lixo. Idem

Foto 30 - Fotografia à distância com Spencer trabalhando. Idem

Foto 31 - Carro coletor de lixo. Idem

Foto 32 - Transeuntes na faixa de segurança. Idem

Foto 33 - Transeunte na bicicleta. Idem

Foto 34 - Placa de indicação. Idem

Foto 35 - Lixeira em loja de alimento. Idem

Foto 36 - Bicicleta estacionada de forma irregular, ao lado de uma lixeira, segundo informação do entrevistado Spencer. Idem

Foto 37 - Lixeiras expostas ao longo do canal Gedempte Gracht, na calçada para pedestres.

\section{A visita ao Museu Zaanse Schans}

Conforme pesquisa por internet sobre as características da cidade, as imagens predominantes eram de uma região turística, uma paisagem idílica com antigos moinhos de vento, tal como nosso imaginário era alimentado pelos quadros de Van Gogh e Monet, entre outros. Por coincidência, descobririam mais tarde que Monet morara por algum tempo em Zaandam, sendo seu estúdio hoje um pequeno museu, localizado a uns $100 \mathrm{~m}$ do nosso hotel. Outra coincidência foi descobrir que o Museu da Cidade, que 
procurávamos para iniciar um levantamento de documentos sobre Zaandam, encontrava-se neste parque turístico.

A próxima tarefa consistiu, portanto, na visita ao museu Zaanse Schans. O Zaans Museum é localizado na região de Zaanse Schans, com características de museu temático e eco-museu. Foi inaugurado em 1994 para preservar e proteger o patrimônio da região de Zaan. Em 2009, o museu foi ampliado com a adição de um prédio de visitação.

$\mathrm{Na}$ estação de trem, elas tiveram dificuldades para a compra de bilhetes. Nenhuma bilheteria ou explicação, nenhum funcionário. Uma passante, vendo sua dificuldade, veio lhes socorrer e ajudar a escolher os itens em um aparelho eletrônico para a compra da passagem. Teriam que viajar algumas estações mais ao norte. No próprio trem havia propaganda do museu e anunciava a presença de fábricas de chocolate.

A voz do condutor ou condutora é sempre em neerlandês. Reconheço algumas palavras em alemão, mas impossível compreender na sua integridade. Com mapa na mão e o google maps acionado nos nossos celulares, encontramos o caminho para o Museu, também anunciado por diversas placas. $\mathrm{O}$ caminho que tomamos era uma rua com canteiros com muitas flores, girassóis, rosas, etc. Lembramos de nossas mães e o amor delas pelas flores e cultivo de plantas. Somos invadidas por um forte perfume de chocolate e logo entendemos que a fábrica gigantesca que se descortina nas proximidades é de chocolate. Na calçada estão dispostos painéis com fotografias do trabalho na fábrica, uma espécie de museu a céu aberto, com fotos antigas e recentes, e vitrines de objetos da fabricação. Na calçada, funcionários estão descansando vestidos a caráter, mas evitamos fotografar. Diário de Cornelia Eckert.

A paisagem em direção ao museu trouxe-lhes a imagem folclórica da Holanda tradicional. A chegada nas proximidades do museu é surpreendente. Estavam em Zaanse Schans, uma vila com casas baixas em madeira, típicas, com moinhos circundando um lago. Seguiram o caminho, atravessando a ponte que se eleva e a qual esperaram que abaixasse. A quantidade de bicicletas era impressionante. Prováveis turmas de alunos que se deslocavam em bandos, conversando. $\mathrm{Na}$ frente carregavam suas pastas e mochilas. Seguiram até o museu e pediram orientação para uma das atendentes. Ela sugeriu que as duas fizessem um tour em outra ocasião, pois não daria tempo de aproveitar todo o circuito. Carmen fez perguntas sobre o museu e sobre transporte público para entenderem a existência, ou não, de cartões mais permanentes de deslocamento.

Visitaram a loja para conferir a disponibilidade de algum livro histórico sobre o bairro. Quase todos os livros em neerlandês. Apenas um guia de passeio em francês com a história resumida da região, o qual adquiriram. Mais uma vez, falaram com a 
mesma funcionária, mas o assunto foram os livros de História e a coleta de lixo no museu. Ela sugeriu conversarem com os funcionários no café.

Pediram um café e entrevistaram a atendente, que prontamente respondeu às demandas. Carmen explica que estavam interessados em conhecer como o museu procede com o seu lixo. A funcionária comentou sobre o sistema de coleta de lixo no restaurante, que é mais ou menos o previsível: ela lhes contou que eles tinham um lixo perto do caixa e que dali o lixo vai para os fundos do prédio, onde uma trabalhadora (ela falou em uma senhora) põe o lixo num container. Esse container é esvaziado uma ou duas vezes por semana. Mas, ao falar da coleta em sua residência, surpreendeu-lhes ao dizer que a prática de seleção, separando orgânico e resíduos sólidos, é recente. A reciclagem obrigatória no espaço doméstico iniciou em Amsterdã em 2019, como provavelmente em todos os Países Baixos.

A interlocutora esclareceu que os prédios têm diferentes latas de lixo marcadas com o número do apartamento. Se o fiscal localiza misturas de latas papel com plástico ou com vidro, ou com lixo orgânico, o apartamento tem que pagar uma multa de mais ou menos 100 euros, cerca de uns 500 reais. Por isso, todos reciclam, concluiu sua interlocutora. No seu edifício, há um depósito para coletar papel, lixo para vidros, lixo para produtos orgânicos, etc.

Após a breve entrevista, fizeram o tour entre as cabanas e moinhos, um museu ao ar livre, aberto e sem controle de tickets. Pararam em uma pequena boutique com objetos usados e observaram as raridades antigas com preços caros. Todo o caminho entre os moinhos é perfumado com o cheiro de chocolate. Muitos comem wafels, ou morango com chocolate, além do usual sorvete com chocolate.

Tiraram muitas fotos, algumas para esta pesquisa e outras para deleite pessoal. 


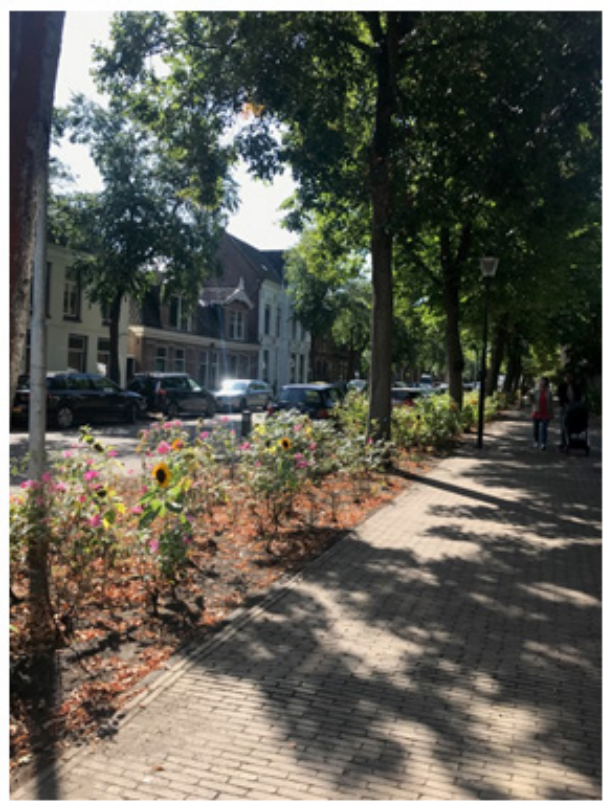

38

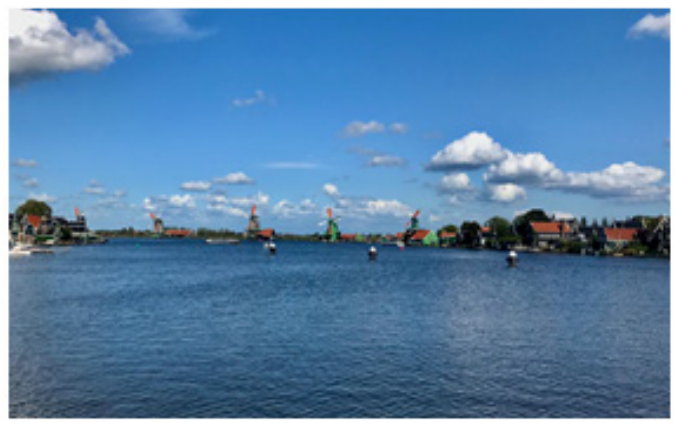

39

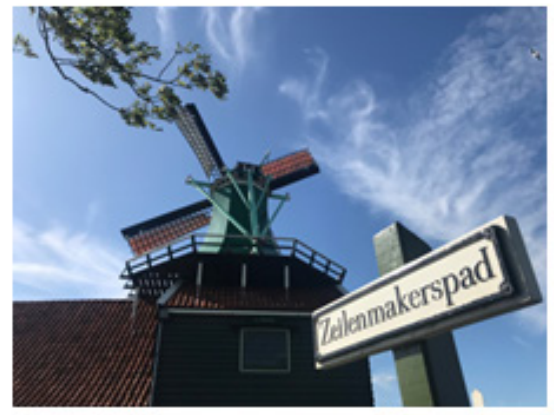

40 


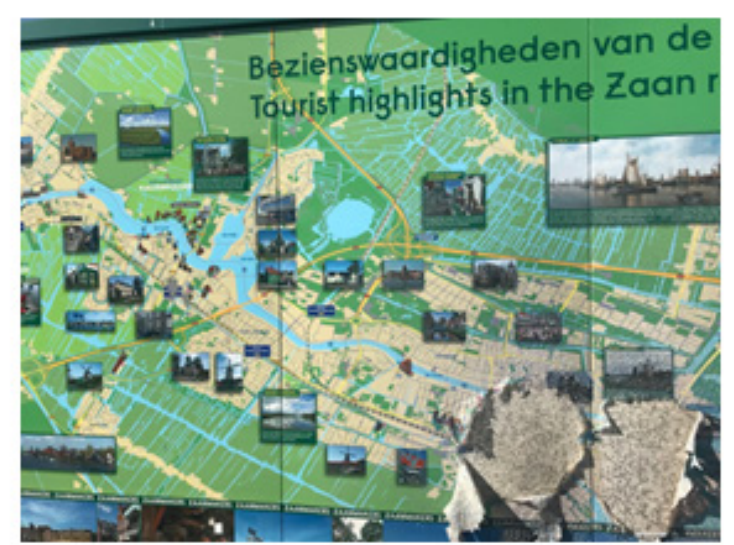

41

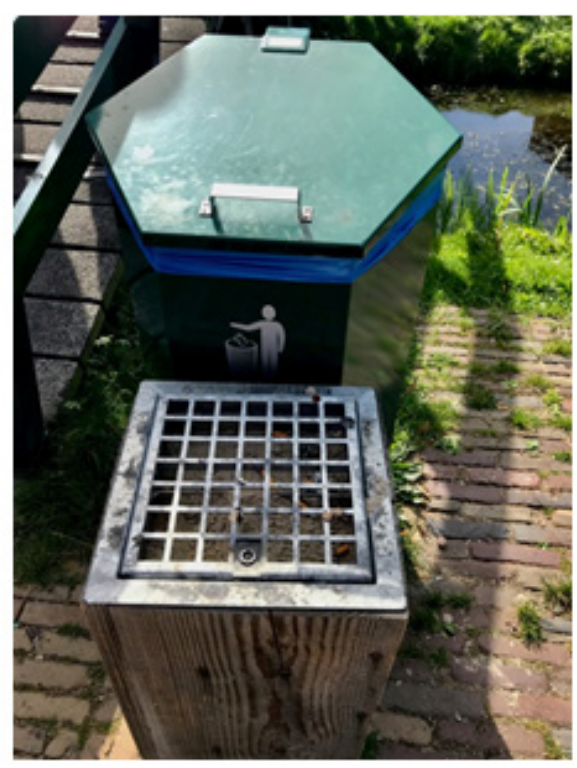

42

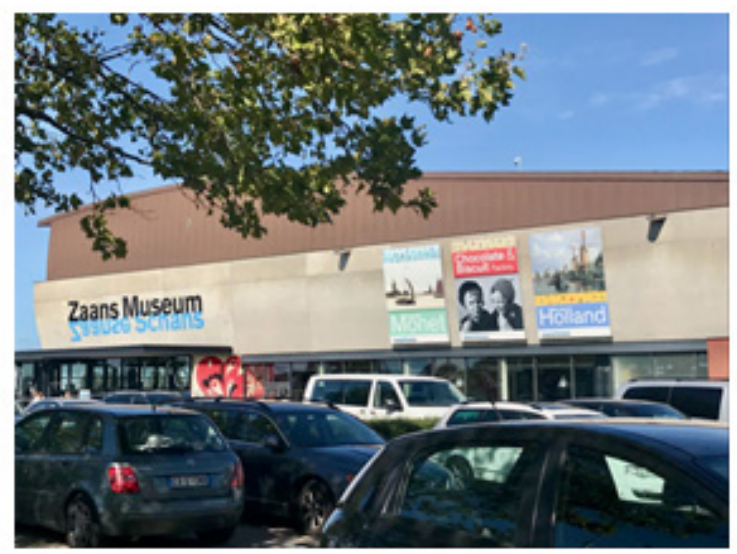

43

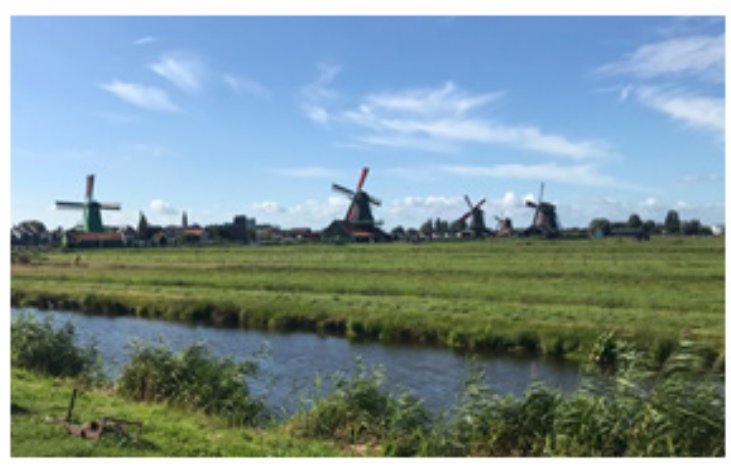

44 


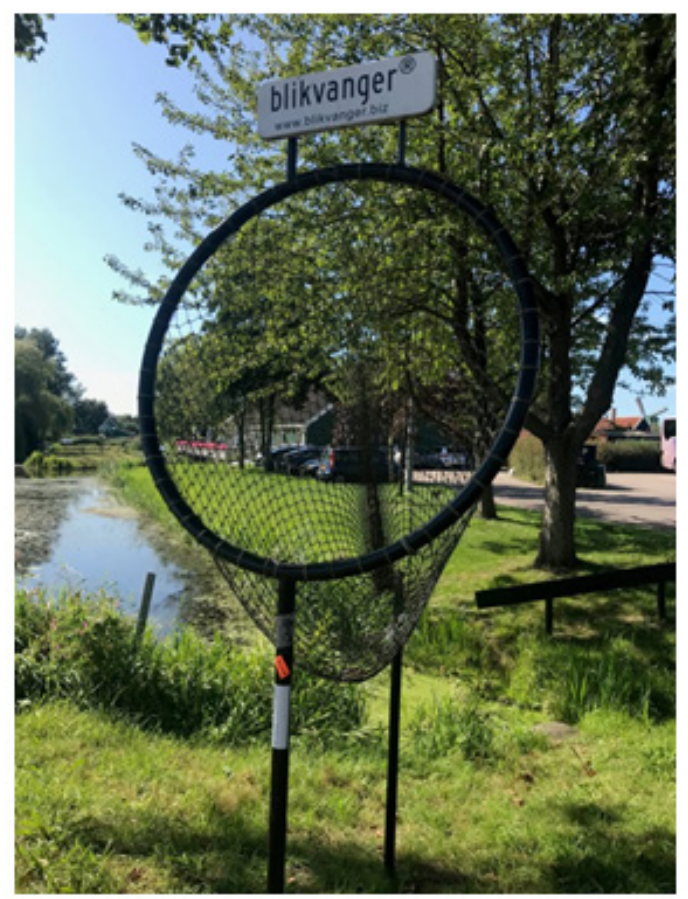

45

38 - No caminho para o Zaans Museum, jardim de flores e um perfume de chocolate no ar. Zaans, Holanda. Foto de Cornelia Eckert, 3 de setembro 2019.

39 - Vista do Zaans Museum. Idem

40 - Vista do Zaans Museum. Idem

41 - Mapa de orientação no Zaans Museum. Idem

42 - Lixeira no Zaans Museum. Zaans, Holanda, Foto de Carmen Rial, 3 de setembro 2019.

43 - Entrada do Zaans Museum. Zaans, Holanda. Foto de Cornelia Eckert, 3 de setembro 2019.

44 - Vista do parque ao ar livre do Zaans Museum. Idem

45 - Coletor de latas e garrafas usadas para ciclistas e passageiros. Idem

Retornaram pelo mesmo caminho, já planejando a caminhada do próximo dia. À noite iniciaram os diários de campo e o trabalho de resguardo das imagens da Etnografia nas ruas do bairro.

No dia seguinte, retornaram ao museu. Dessa vez chegaram cedo para conhecer e obter as informações sobre o território reputado como a mais antiga zona industrial do mundo, sendo a primeira serraria datada de 1596. O projeto do museu é arrojado, no estilo de museu-espetáculo para lembrar as obras críticas de Henri Jedy, Mike Featherstone ou Arjun Appadurai, entre outros autores que discutem o consumo na contemporaneidade.

O parque revitalizado é composto de moinhos e fabriquetas, cada um dedicado a uma produção: serraria, queijos, tamancos, cereais, sementes, velas e, claro, chocolate, etc. A maioria desses pavilhões hoje abriga oficinas de artesanato, de doces típicos e 
joias. O museu traz a história da importância da construção de diques, do comércio marítimo, da caça às baleias até a indústria de chocolate e de doces, que é hoje uma potência na região e, ainda, da produção de estanho (Blaauboer). As placas citam aspectos históricos como a construção dos diques, o aproveitamento da terra para o cultivo, permitido graças aos moinhos. Entre outras informações importantes:

Combinados com os inúmeros estaleiros, fabricantes de vela, forjas, fundições de baleias e cordéis, essas fábricas fizeram da região de Zaan a área industrial mais importante da Europa.

A invenção da serraria teve um papel importante. Zaandam tornou-se o centro europeu de construção naval. As serrarias da região de Zaan cortam a madeira destinada à construção da frota de Amsterdã, mas também das casas da capital.

A maioria dos moinhos é, portanto, para a visitação turística, embora conste em flyers que oito moinhos ainda funcionam na borda do rio Zaan. Mas, nos séculos passados, chegaram a mil. A maioria era de moinhos industriais, poucos eram para bombear água.

Ao longo do parque, encontraram também as casas de operários e as casas de comerciantes, algumas delas efetivamente ocupadas por seus atuais moradores. As construções com detalhes arquitetônicos eram restritas aos mais prósperos. Uma casa com a inscrição de 1742 pertencia, em sua origem, a um usineiro de cacau. Este afortunado apresentava jardins inspirados no modelo francês ou inglês. As residências mais pobres eram originalmente de pescadores e, como diz o panfleto turístico, "aqui você descobre as condições de vida de uma família de pescadores de 1850”. (Walk Guide, Zaanse Schans, 2017). A pesquisa que fizeram dias depois com imagens no site da prefeitura mostrou uma realidade mais dura do que a representação higienizada que o museu hoje exibe.

\section{Buscando a prefeitura, encontrando Spencer}

No retorno do Zaans Museu, as duas foram pesquisar no Centro Municipal. A administração municipal de Zaandam fica em um prédio situado entre a estação de trem (metrô de superfície) e a avenida central do bairro, como já anunciamos.

Ao caminharem em direção ao prédio, perceberam funcionários limpando o canal nas proximidades do Inntel Hotels, o já citado prédio, composto de 70 formatos de casinhas típicas holandesas. 


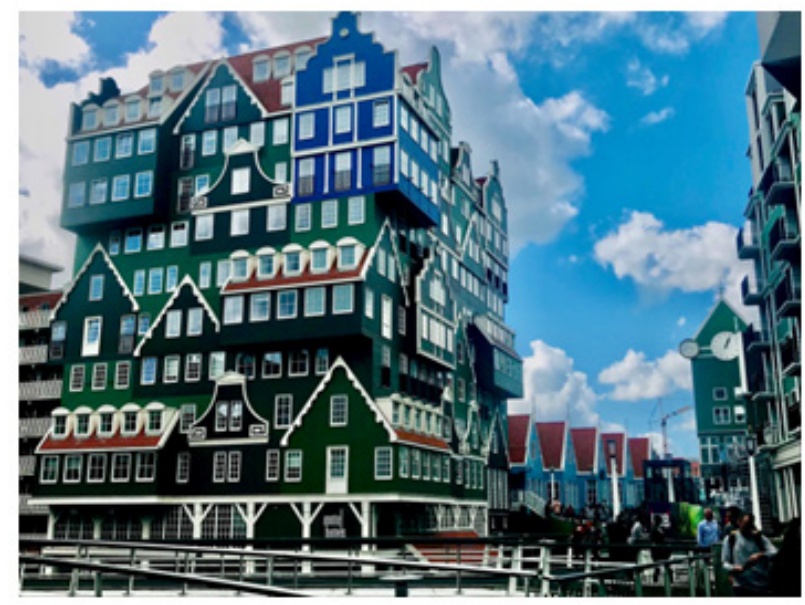

46

46 - Inntel Hotels. Zaandam, Holanda, 3 de setembro 2019. Foto de Cornelia Eckert, 3 de setembro 2019.

O tanque, que ontem estava cheio d'água, encontrava-se esvaziado, e funcionários limpavam-no com mangueiras de pressão. Paramos para fotografar e filmar esse processo.

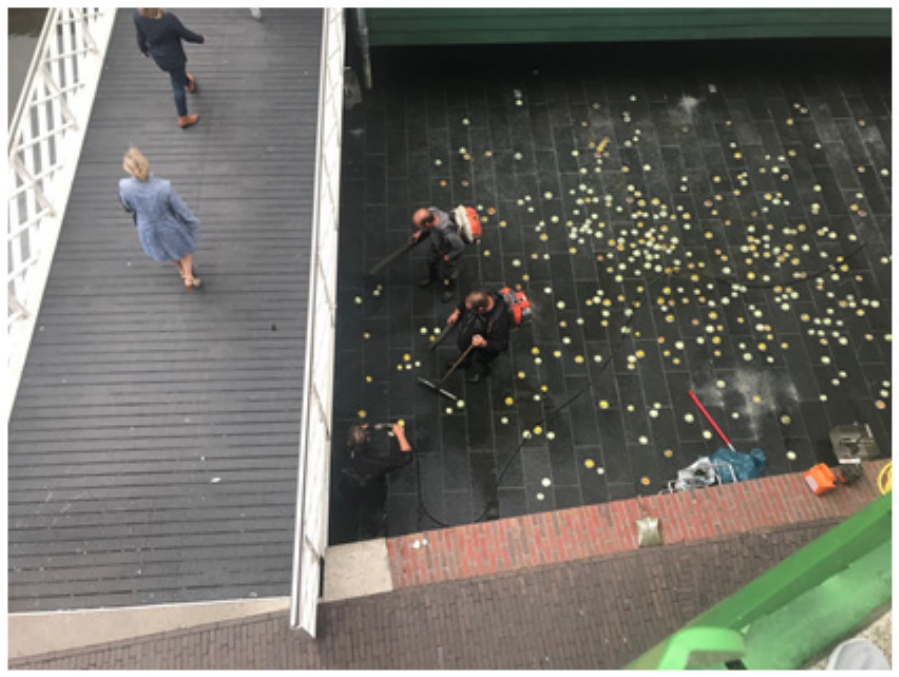

47

47 -Limpeza do canal por empresa privada. Zaandam, Holanda, 3 de setembro 2019. Foto de Carmen Rial, 3 de setembro 2019.

Ao reiniciarem sua caminhada, nas proximidades do prédio, logo avistaram novamente Spencer com seu carrinho de golfe de coleta de lixo, em plena atividade. Cumprimentaram Spencer, que parou o carro e desceu do mesmo para conversar com as 
pesquisadoras. Cornelia apresentou a colega Carmen, e Spencer retirou as luvas para cumprimentá-las e passaram a falar em português. Carmen ligou o gravador, sem apontar a câmera para o rosto do funcionário. Spencer falava com certa fluência, e elogiaram seu português. Primeiro perguntaram sobre o processo de limpeza que acabavam de observar. Explicou que este procedimento era realizado por firmas privadas contratadas pela administração. Carmen perguntou se a responsabilidade não caberia à prefeitura ou se ele próprio não teria esta tarefa. Ele explicou que não. Que sua tarefa de limpeza de canal não implicava esvaziar e limpar este poço, como haviam observado. Que esta tarefa é realizada três vezes ao ano pela empresa privada, especializada neste tipo de limpeza. Que não cabia aos garis realizar esta tarefa.

Enquanto conversavam uma ou outra vez, Spencer cumprimentava alguns passantes. O movimento no local era intenso por estar nas proximidades da estação do trem. Spencer seguiu explicando-lhes suas tarefas.

Mudaram de pergunta, agora sobre os problemas do lixo em Zaandam. Spencer explicou que o maior problema são as pessoas. Que elas não cumprem com as regras e jogam lixo em locais inapropriados. Que não há educação e que, atualmente, os jovens pouco se importam com as orientações paternas. Carmen perguntou em relação ao filho e aos jovens em geral, se não havia educação ambiental ou como recebiam as informações de uma cultura ambiental. Ele respondeu que havia, sim, alguma formação ambiental nas escolas, mas que dependeria, sobretudo, da educação dos pais. ${ }^{4}$

Importante foi reforçar a política atual para o lixo selecionado. Spencer explicou que cada edifício tem os containers com cores diferenciadas, conforme o suporte a ser coletado, e um número de identificação. Esclarece que cada morador porta um cartão eletrônico para abrir o lixo e, assim, poder fazer o depósito dos rejeitos. Mostrou para as pesquisadoras o seu cartão, e elas fotografaram.

\footnotetext{
${ }^{4}$ Como estávamos gravando, com o seu consentimento, pedimos para recontar sobre sua própria trajetória. Novamente contou que morou no Brasil por quatro anos; que se apaixonou por uma brasileira e passou a viver com ela. Os familiares desta mulher possuíam um comércio, e ele passou a trabalhar neste comércio. Com ela teve um filho. Depois de se separarem, retornou para Holanda, e o casal achou melhor o filho viver na Holanda, onde teria estudo e maiores oportunidades de formação. Depois disso, não retornou para o Brasil. Quanto aos seus pais, seu pai é chinês e agora vive novamente na China. Quando imigrou, trabalhou em comércio. Sua mãe é meio holandesa, meio Suriname. Ela ainda vive em Amsterdã. Carmen retorna para o tema família, sobre sua relação com o filho. Ele explica ser bem severo. Quando o pai pergunta ao filho se ele pode buscar algo no comércio, o rapaz responde que não, e ele pergunta ao jovem qual foi mesmo a resposta? $\mathrm{O}$ filho responde que havia perguntado se ele poderia ir ao comércio, e que ele respondera que não. Então Spencer disse, bem eu não pergunto mais. Agora estou mandando que você vá no comércio trazer alguma coisa. Spencer ri de sua performance com o filho.
} 


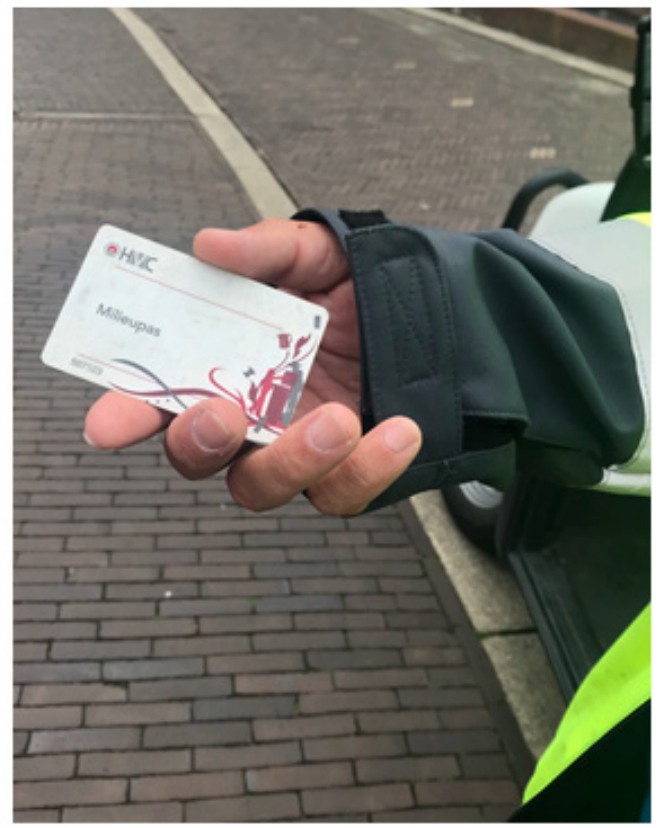

48

48 - Spencer mostra o cartão para acessar o container do seu edifício. Zaandam, Holanda, 3 de setembro 2019. Foto de Carmen Rial, 3 de setembro 2019.

Aproveitaram para perguntar a Spencer onde seria o festival previsto para o próximo final de semana, que comentara. Ele mostrou um Outdoor com a propaganda do evento e explicou que o espaço é na altura da loja Hema.

Despedimo-se de Spencer e seguimos observando. Ele encontrou colegas próximos a um lixo coletor e trocaram ideias. Elas fotografaram.

\section{A visita à prefeitura}

Ao entrarem no prédio, perguntaram na recepção sobre onde poderiam encontrar informações a respeito da história do bairro. Indicaram-lhes a sessão de biblioteca e arquivos. Neste setor foram recebidas por funcionários, e Carmen explicou sobre o interesse delas por informações. O funcionário chamou uma atendente dos arquivos. Carmen, mais uma vez, explanou as razões de estarem lá em busca de dados sobre a história do bairro e que lhes interessava, em particular, informações sobre o tema do lixo, da reciclagem e do meio ambiente. Rapidamente a atendente, que se apresentou com o nome holandês, Geke van de Kamp e, percebendo a dificuldade delas em pronunciar seu nome, simplificou-o para Maria. Disse estar, no momento, muito ocupada, mas que poderia fornecer informações históricas e imagens sobre a questão 
sanitária e ambiental do bairro. Indicou-lhes um endereço de site da municipalidade com arquivos e marcou um encontro para quarta-feira. Carmen disse que traria seu cartão de professora e pesquisadora da UFSC e ABA.

Fotografaram as paredes do local, ornamentado de fotos antigas.

Quarta-feira, dia 4 de setembro. Por volta das 14 horas, retornamos ao centro municipal e, primeiramente, visitamos uma sessão de exposição sobre uma fábrica de objetos para alimentação infantil. Também há um caderno com toda a programação do evento no próximo sábado, com atividades de música, teatro, performance, comida, etc. Aparentemente uma data importante no calendário municipal de encontro da comunidade.

Procuraram por Maria na sala da biblioteca. Carmem apresentou seus cartões, e ela fotografou. Maria pergunta o que elas gostariam de saber, em voz baixa, pois estavam em uma biblioteca. Carmen expôs nossas questões. Falaram que lhes interessava o tema da vida cotidiana e reforçaram sua motivação pela revitalização, gentrification, reforma urbana, origem do bairro e claro, o tema do lixo e reciclagem. A funcionária explicou que é um bairro de origem operária e industrial e que, por isso, a significativa presença de imigrantes turcos que vieram para responder à demanda de mão de obra nas indústrias. Comentaram que haviam, ontem, passado nas proximidades de uma grande indústria de chocolates. Maria também fez referência ao Museu de Zaandam, e elas esclarecera, que já haviam visitado essa instituição e obtido algumas informações históricas.

Maria mostrou-lhes na sua tela o site da municipalidade onde poderiam acessar as imagens de acervo da história do bairro e indicou-lhes, em especial, as imagens referentes ao saneamento básico no local. São fotos que mostram como o sistema de fezes fazia a coleta por barcos e caminhões e fotos do processo de coleta do lixo e das fezes na época. Mostrou-lhes outras fotos de trabalhadores, do cotidiano, e as pesquisadoras fotografaram e anotaram as informações do site. 


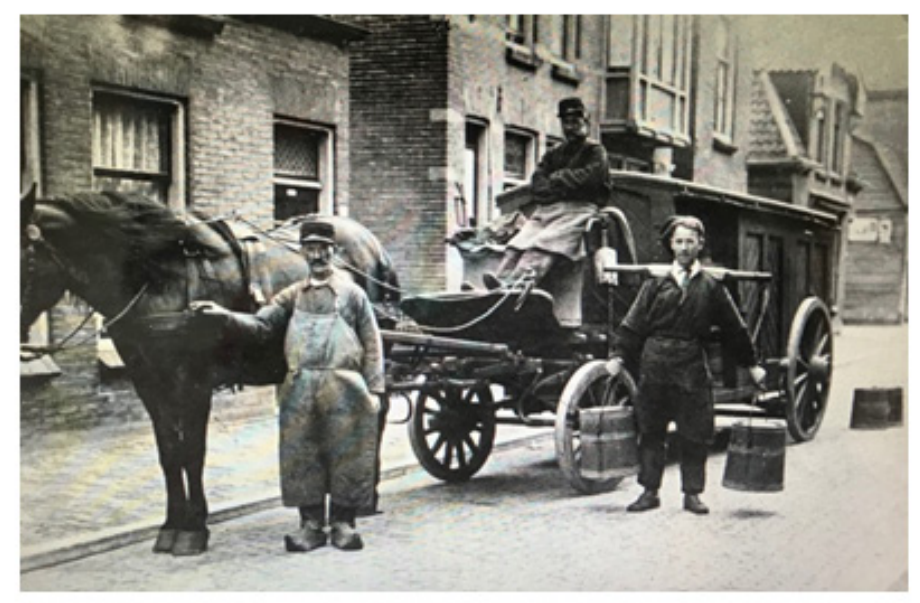

49

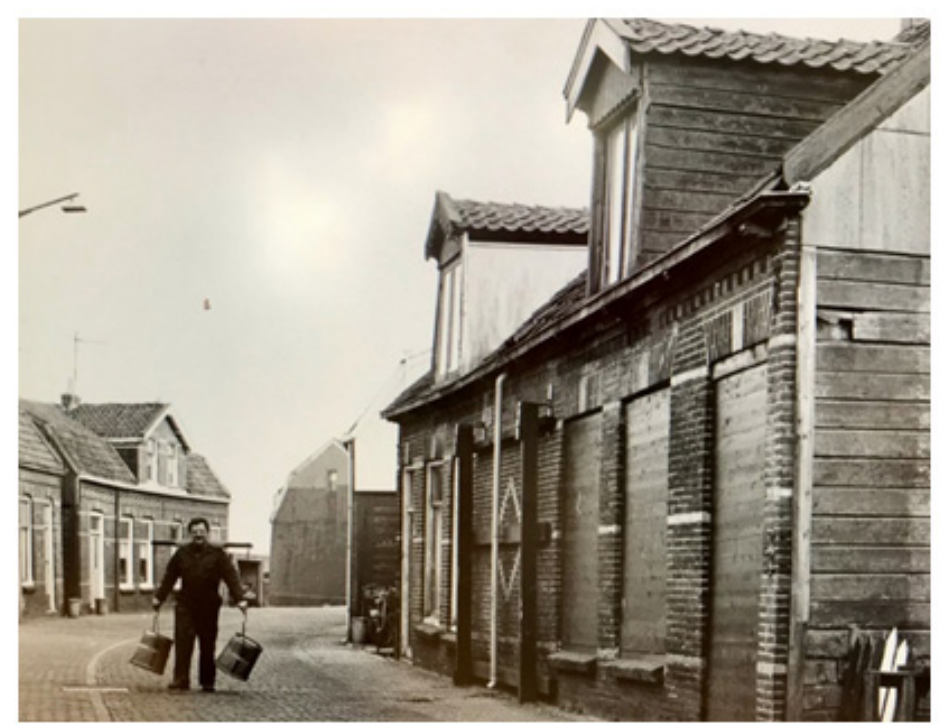

50 


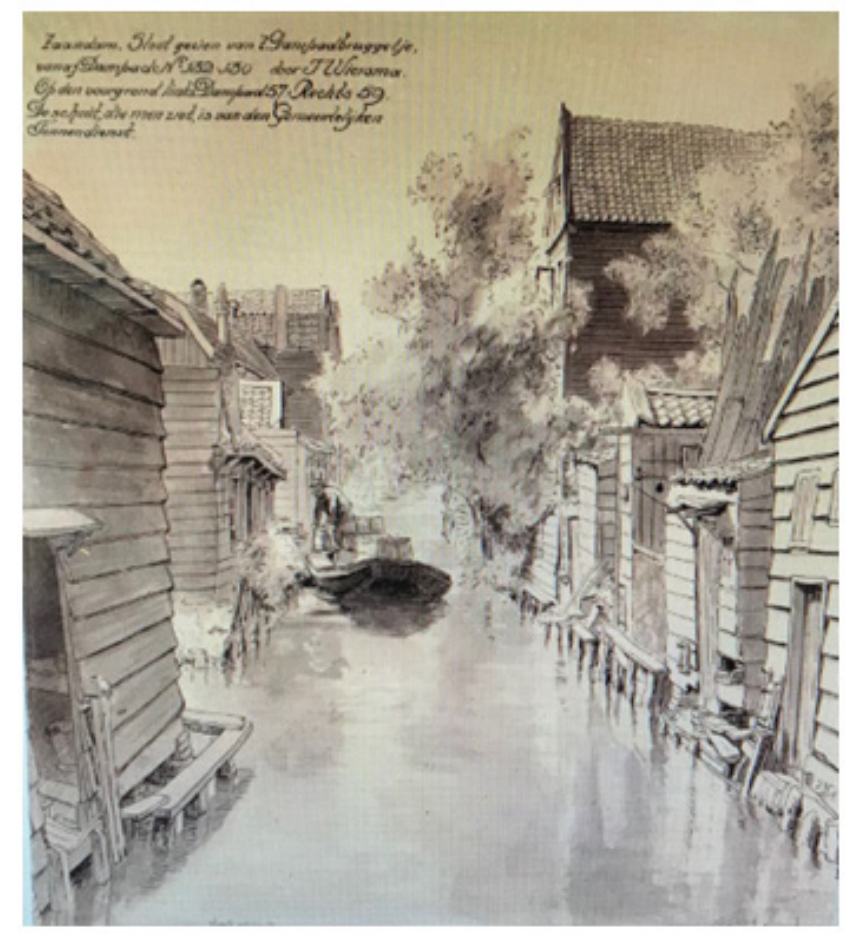

51

49 -Carroça coletora de excrementos. Imagem do acervo da prefeitura de Zaandam. Zaandam, Holanda, 4 setembro 2019.

50 - Carregador de baldes com excrementos. Imagem do acervo da prefeitura de Zaandam. Zaandam, Holanda, 4 setembro 2019.

51 - Barco coletor de baldes com excrementos. Imagem do acervo da prefeitura de Zaandam. Zaandam, Holanda, 4 setembro 2019.

Sobre a política de reciclagem do lixo, apresentou algumas imagens antigas, e Carmen perguntou sobre a atual política. Maria explicou o que Spencer já havia adiantado, sobre cada edifício ter seus containers com cores diferentes para a seleção e separação dos rejeitos por sua natureza: orgânicos, vidros, papel, plásticos, etc. Mostrou-lhes o mesmo tipo de cartão para acessar os containers, que levava preso com um fio de plástico em sua cintura, dando ideia de uso frequente, junto com suas chaves.

Perguntaram um pouco sobre sua vida pessoal, mas ela explicou não ter história vinculada ao bairro e que trabalhava cerca de cinco anos nessa municipalidade. Combinaram, então, uma entrevista que ficou marcada para dia 05 de setembro, às $8 \mathrm{~h} 15 \mathrm{~m}$, quando Maria avisou que teria menos movimento na biblioteca.

Ainda perguntaram pela Secretaria do Meio Ambiente, que a recepção disse não existir, mas a moça passou-lhes o telefone do órgão que julgava ser responsável pelo lixo urbano. 


\section{Na trilha dos lixos coletores}

Várias foram as caminhadas com equipamento para fotografar e filmar caixas coletoras nas ruas de Zaandam. A cada dia, avançavam uma rua a mais e se deixávamos perder entre ruas e bairros. Ora se restringiam à área nos entornos do canal central, ora atravessavam a ponte para conhecer o outro lado da cidade. Todo o deslocamento era feito a pé.

$\mathrm{O}$ caminho mais frequente, ao sair de casa, visava às ruas que circundam o canal, sempre a partir da avenida principal. Desta vez, o percurso foi feito para ter mais atenção aos equipamentos urbanos até chegarem na ponte maior no final da rua central, onde, aliás, se localiza o atelier de Monet, uma pequena casa nas margens do rio Zaan.

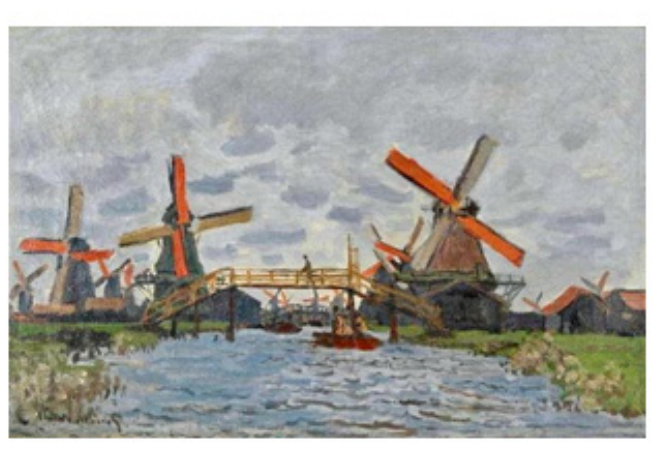

52

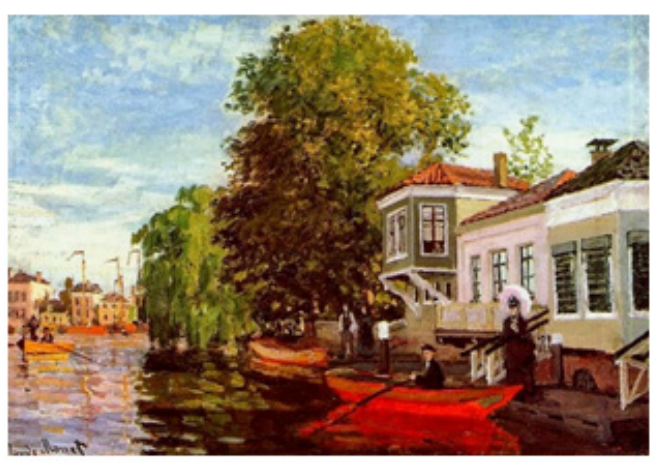

53

52 - Monet 1871 - The Zaan at Zaandam

Fonte: https://commons.wikimedia.org/wiki/File:Monet_1871_The_Zaan_at_Zaandam.jpg

Consulta 4 setembro 2019.

53 - Moinhos em Zaandam - Claude Monet - 187.

Fonte: https://www.pubhist.com/w36528

Consulta 4 setembro 2019.

Outro dia percorreram as ruas laterais da Avenida principal. As ruas mostram os fundos das inúmeras lojas comerciais e diferentes tipos de coleta de lixo. Fotografaram os diferentes tipos de lixo, alguns sacos no chão e também alguns resíduos na calçada. Do outro lado, algumas moradias e instituições como a igreja evangélica, escolas e outras lojas comerciais.

$\mathrm{Na}$ ponte maior, levadiça, tentaram entrar no atelier de Monet, conforme anunciava o cartaz no início da ponte, mas este estava desativado. A placa informava ter sido casa do pintor, onde recriara a paisagem de Zaandam em telas. Na avenida paralela ao rio, o comércio é igualmente intenso, com diversidade de gêneros de consumo. São várias lojas, boutiques, escolas com muito movimento de bicicletas e carros. 
No outro dia, Carmen, ocupada em uma aula remota via Skype, e Cornelia etnografou sozinha a caminhada. Tirou fotos da performance dos usuários de bicicletas que andam em duplas, conversando e às vezes se apoiando um no outro. Para traçar um roteiro, dirigiu-se até a igreja cuja cruz era vista a distância e encontrou uma praça grande, mas a igreja milenar estava fechada com sinais de reforma.

Nesta caminhada, me decepciono por não poder visitar a igreja. Aliás, todas as igrejas, até então, estavam sempre fechadas. Resolvo, então, adentrar o interior das ruas do bairro em busca de informações sobre os tipos de habitação e acerca do uso do lixo. Me chama a atenção nesta caminhada que cada rua tem uma característica de habitação. Em algumas ruas, podemos observar a sequência de casas baixas, com grandes janelas e sem cortina, mostrando a importância que os holandeses dão para a penetração da luz em suas casas. Dos janelões, de modo geral, observo a ornamentação interna, com flores, brinquedos e outros objetos. Na rua sempre algum vaso, alguma flor plantada, árvores e pouca presença do lixo; este, provavelmente, no fundo das casas. Isto muda nas ruas onde há condomínios e edifícios, ou ainda casas geminadas. Neste caso é possível constatar os coletores de lixo ora de metal, ora de plástico e, em algumas ocasiões, já os containers com diferentes cores (verde, azul, amarelo), coletando o lixo de modo diferenciado para reciclagem ou incineração.

Após esta longa caminhada, registrei os canais, pontes, patos, vegetação ribeirinha, gatos, ovelhas, muitas canoas para uso pessoal próximo as casas que beiram os canais, e muitas pessoas passeando com seus cães para as necessidades. Finalizei a caminhada. Retornei exausta para o hotel. (Diário de Cornelia Eckert).

\section{O site da municipalidade}

Para prepararem a entrevista agendada com Geke/Maria, pesquisaram o site da municipalidade e baixaram arquivos de fotos e vídeos disponíveis no youtube. São filmes de diferentes épocas. Um filme produzido em 2006 mostra Zaandam de 1960, ainda com características de vila. Já os filmes dos anos 1980 mostram ter sido um período de revitalização. Em 1983, a rainha Beatriz inaugurou a nova estação de trem da cidade. Há excelente material trazendo fotos históricas, como a que registra a importância da vinda do czar Peter de Grote, que lá se instalou para conhecer a arte da construção de navios. Há um museu dedicado a ele, localizado em uma casa de madeira de 1632, a mesma onde se hospedou, com a intenção de estudar a fabricação de navios. Zaandam foi o grande centro de construção naval que alimentou a Companhia das Índias Ocidentais (as que dominaram Pernambuco) e das Índias Orientais (as que implantaram as colônias holandesas na Ásia). 


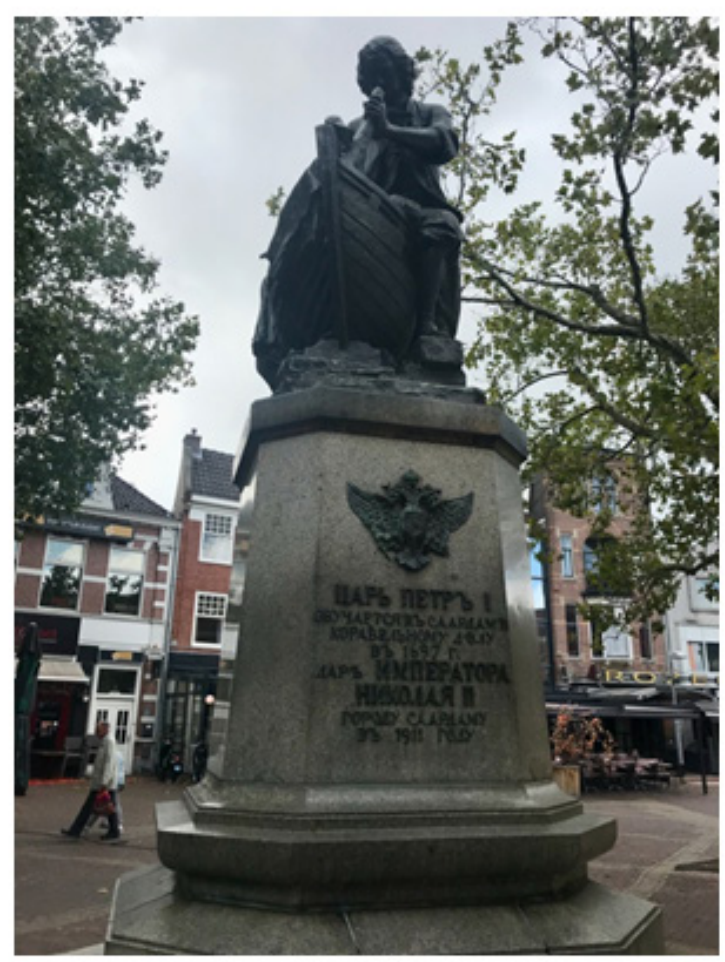

54

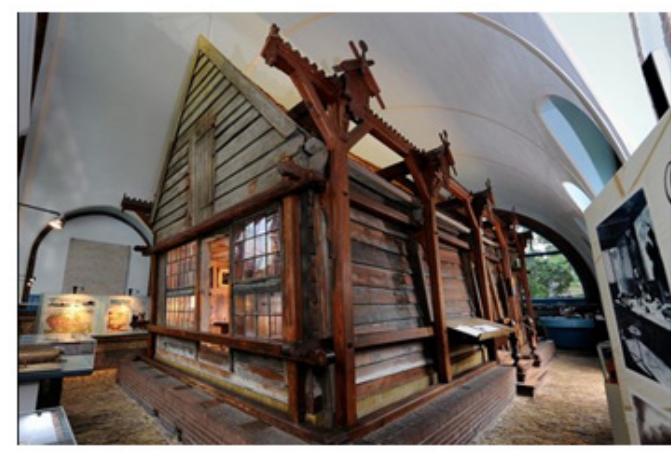

55

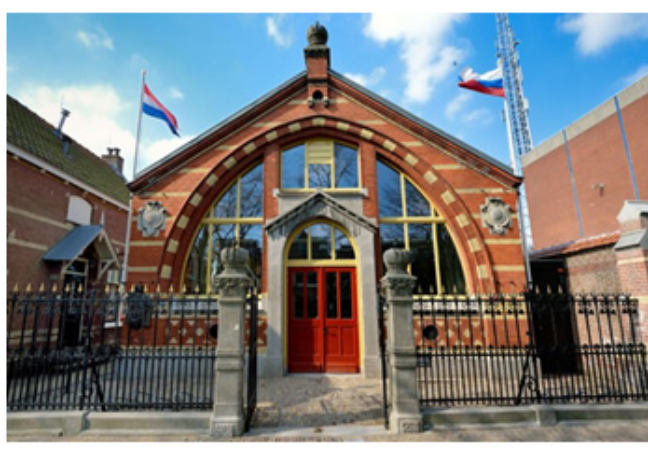

56

54 - Monumento de 1911, presente do Keiser Nicolaas II para a cidade de Zaandam, em homenagem ao Czaar Peter I.

55 - Choupana onde Czaar russo Pedro, o Grande, viveu por oito dias em 1697, quando estudou construção naval na Holanda, interior do Museu Zaans. Fonte: https://historiek.net/president-poetinontvangt-stukje-van-czaar-peterhuisje/21931/ Consulta 7 setembro 2019.

56 - Museu Zaans, construído ao redor da casa em que o czar russo Pedro, o Grande, viveu em 1697. Fonte idem.

\section{Uma cidade operária}

Em mais um dia de caminhada na rua e mais um dia de chuviscos, elas percorreram a cidade por uma rua lateral à principal, Rosengrach. De um lado da calçada são os fundos das lojas comerciais, mas a limpeza, de modo geral, chama a atenção. Do lado direito, algumas lojas comerciais, outras residenciais. Não raro viram 
comércios fechados em estabelecimentos abandonados, como a padaria. Embora anunciada por placas, parecia abandonada e com entulhos.

Fotografaram alguns poucos resíduos nas calçadas e, no final da rua, dobraram à direita, até chegarem na rua Klimp, e logo encontraram a casa do czar Peter, próxima a uma estátua dedicada a ele. Fotografaram e, na sequência, já estavam em uma zona de pequenas casas e muito ajardinamento.

Apesar do mal tempo, atravessaram a ponte menor e caminharam do outro lado do rio Zaan, por uma zona bem residencial, com diferentes tipos de condomínios, ora edifícios, ora casas geminadas, todos com características populares.

$\mathrm{Na}$ frente da mesma casa, um grande parque infantil com vários tipos de equipamentos enfileirados para brincar. Retornaram pela mesma ponte e, apesar do frio e do vento, testemunharam um nadador no rio. Estupefatas com a cena, ficaram observando. Bem próximo a elas, o nadador sorriu e abanou, cumprimentando. Carmen gritou-lhe que estava muito frio e que ele era muito corajoso, e Cornelia fotografou. Ficaram admirando o seu nado por volta de 20 minutos, até que saísse nos fundos de uma casa e se enrolasse na toalha. Ao testemunhar o banho de um morador, naquelas águas, podiam pressupor a qualidade ambiental do rio. Uma pergunta que terriam que pesquisar, uma vez que inúmeras fábricas bordam o rio, e a poluição da água provavelmente havia sido superada em algum momento. 


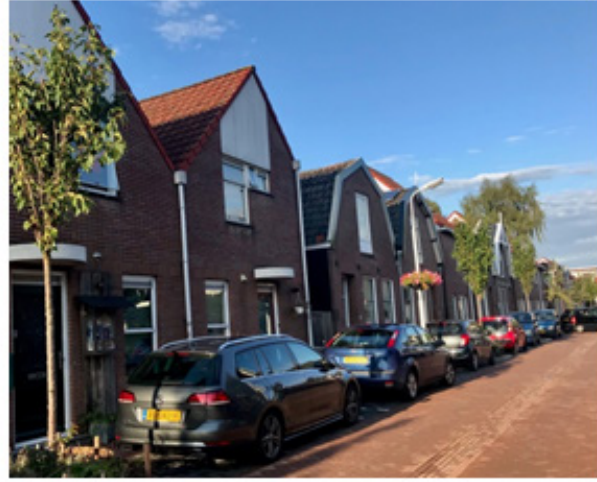

57

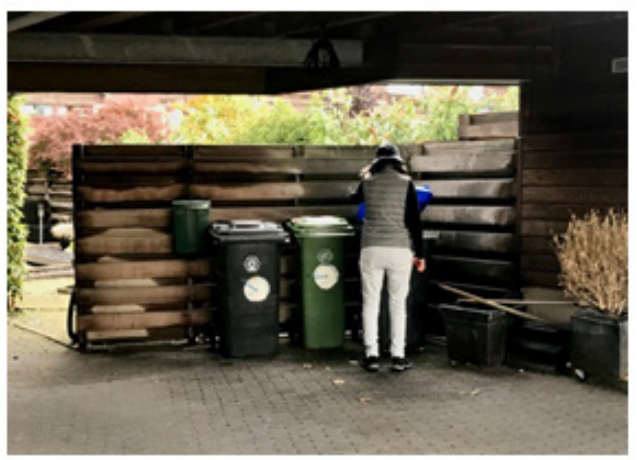

59

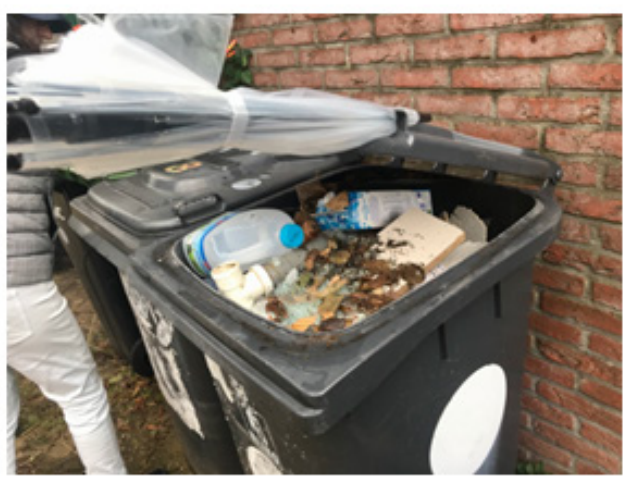

61

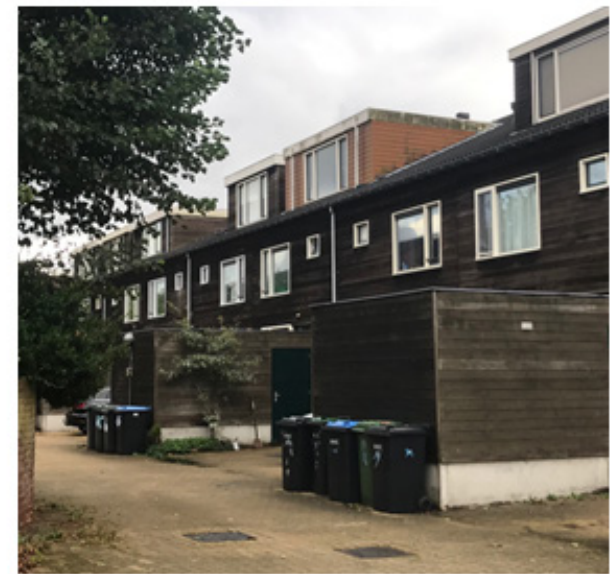

58

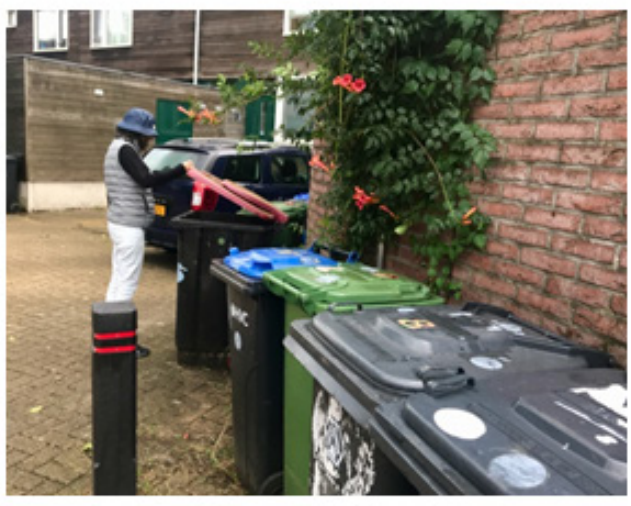

60

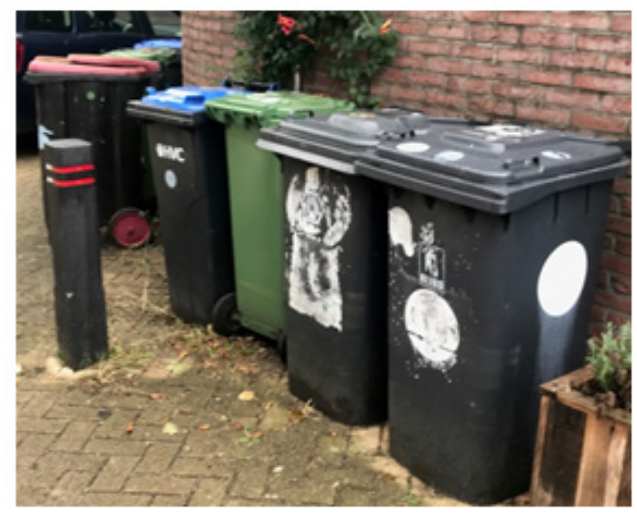

62 


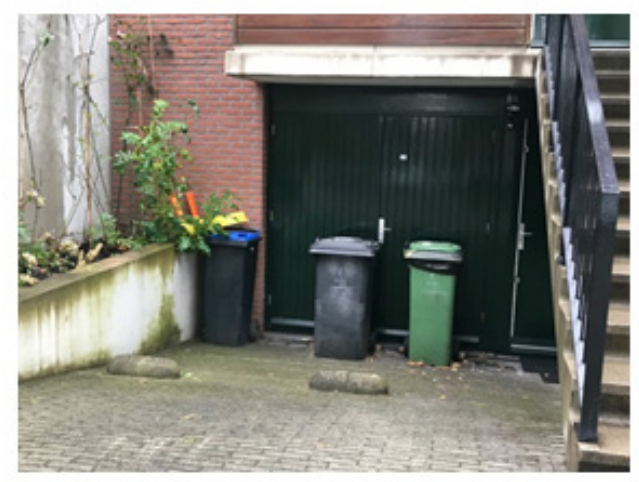

63

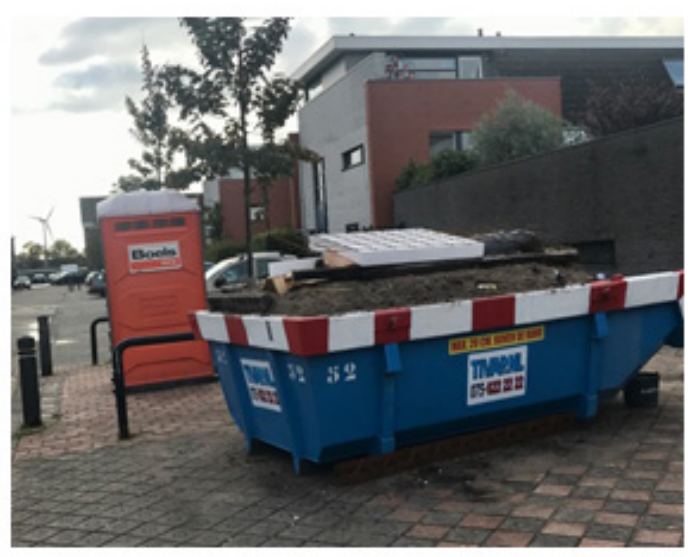

65

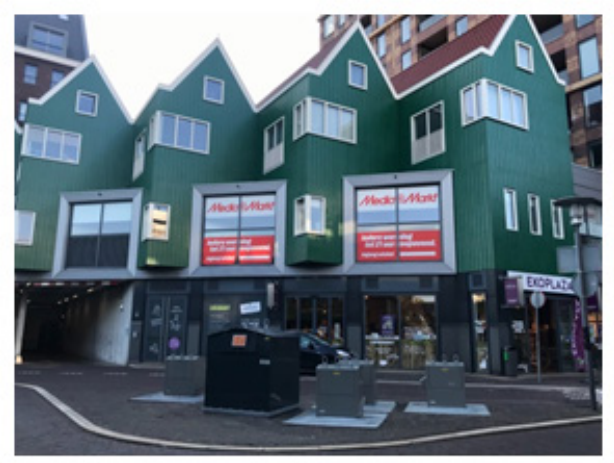

67

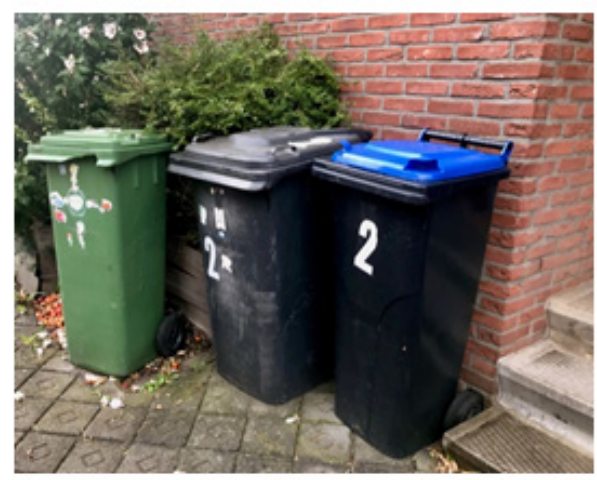

64

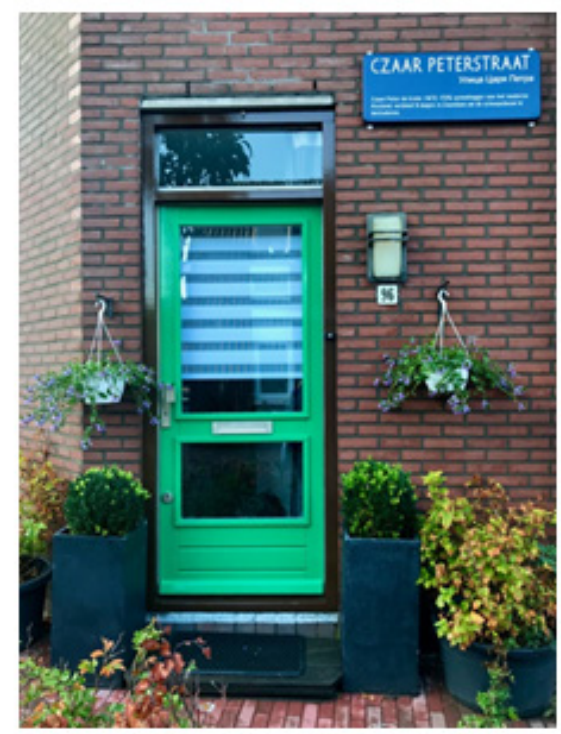

66

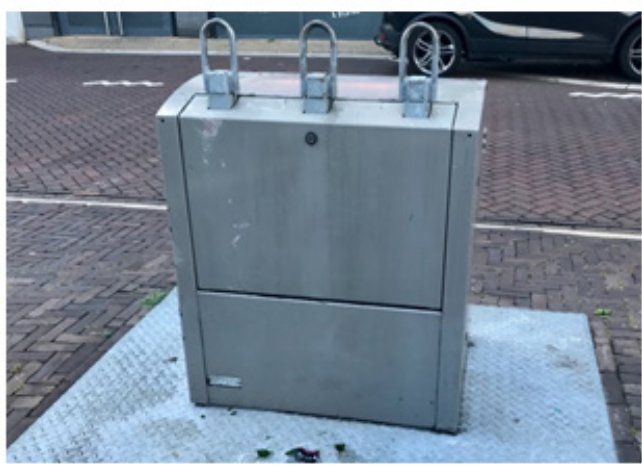

68 


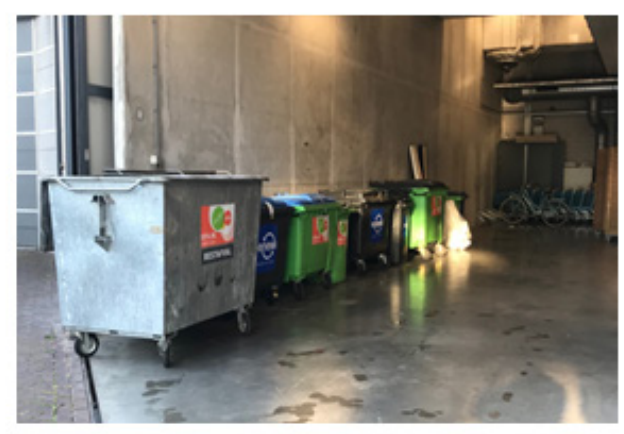

69

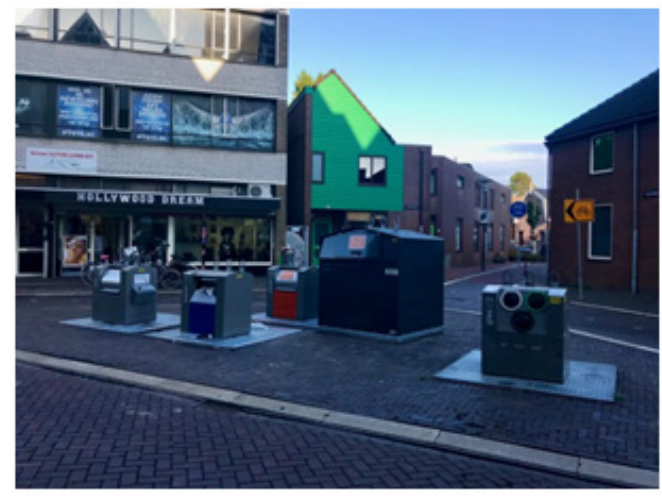

70

57 - Sequência de casas populares. Foto de Cornelia Eckert. Zaandam 6 setembro 2020.

58 - Observando os containers nas residências. Foto de Cornelia Eckert. Zaandam 6 setembro 2020.

59 - Idem

60 - Idem

61 - Idem

62 - Idem

63 - Idem

64 - Container de entulhos. Idem

65 - Ponte que atravessamos para retornar por outro bairro operário mais antigo. Idem

66 - Porta de entrada de uma casa operária, embora sem jardim frontal, florida. Idem

67 - Containers nos fundos de uma loja média. Idem

68 - Containers de subsolo próximo a loja de grandes proporções. Idem

69 - Idem

70 - Idem

Retornaram por outras pequenas ruas nas proximidades da casa do Czaar. Logo se depararam com casas geminadas e pequenas. Uma placa dizia ser a rua Tolstoi e havia a inscrição de algumas palavras em russo. Perceberam ser um bairro operário e ficaram curiosas em conhecer a história imigratória relacionada a este contexto.

As casas geminadas, sem jardim frontal, caracterizam residências de trabalhadores desde os séculos iniciais do processo industrial. O estado das casas era de conservação, mas não de revitalização, em contraste com o eixo central da cidade.

Elas retornaram por um outro caminho, marcado por pequenas pontes e canais menores que emprestam ao lugar uma paisagem muito rústica e harmoniosa, sempre com presença de aves como patos e outros pássaros. Por todo o percurso, fotografaram as latas de coleta de lixos orgânicos e de resíduos sólidos, que iam se somando no seu acervo de pesquisa. 


\section{Cidade segregada}

"Vocês estão onde mesmo? Em Zaandam? Nossa! É muito diferente de Amsterdã.”

Esta é a surpresa de sua colega holandesa, residente em Amsterdã, que conheciam de intercâmbios entre Brasil e Holanda, ao comunicar que estavam instaladas em Zaandam.

- “Como assim?”, respondemos, "nós estamos em Amsterdã, na periferia."

- "Não, não. Zaandam é outra cidade. Amsterdã é ciência e arte. Zaandam é fábrica e classe trabalhadora. Amsterdã segrega Zaandam por sua origem operária.”

O motivo do seu contato era justamente buscar conhecidos de sua amiga em Zaandam para entrevistas a partir de sua rede de afinidades. Sua colega informou-lhes que não conhecia ninguém em Zaandam. Perguntaram sobre o que conhecia do bairro. Explicou que Zaandam é considerada uma outra cidade e completamente diferente Amsterdã. Esclareceu que a segregação era ainda evidente entre os habitantes da capital e essa periferia.

Zaandam, portanto, mantém essa forte identidade de zona industrial e habitada por descendentes de classe operária, com um número expressivo de imigrantes. Mas também é uma região de forte turismo, pela revitalização da zona de moinhos para visitação, conforme narraram.

\section{A entrevista com Geke/Maria - Sociedade limpa, sociedade de vigilância}

Cedo, pela manhã daquela quinta-feira (5 de setembro), dirigiram-se à prefeitura municipal para encontrarem Maria na biblioteca municipal. No dia anterior, haviam preparado um roteiro que registrava aspectos da trajetória pessoal, sobre a história de Zaandam e as questões acerca da gestão do lixo. Também previram, no roteiro, mostrar as imagens que haviam produzido para gravar seus comentários.

Dado ser cedo da manhã, a biblioteca estava ainda vazia quando Maria as recebeu. Ocuparam uma mesa e passaram a gravar. Maria é bibliotecária há 15 anos e está lotada no acervo histórico de Zaandam. Além do trabalho como bibliotecária, organiza oficinas sobre literatura para adultos (“a maioria tem mais de 50 anos"). Citou especialmente um curso, de Carry van Bruggen ${ }^{5}$, uma autora nascida em Zaandam,

\footnotetext{
${ }^{5}$ Carry van Bruggen (1 de janeiro de 1881 - 16 de novembro de 1932) foi uma escritora holandesa que também escreveu sob o nome Justine Abbing. Uma das 16 crianças de Izak de Haan e Betje Rubens, ela nasceu Caroline Lea de Haan, em Smilde, e cresceu em Zaandam, tendo estudando para se tornar
} 
cujas ideias feministas foram expressas em romances e ensaios. "As pessoas leem os seus livros, e eu levo material de arquivo, fotos, para ilustrar sua literatura, escrita entre os anos dos anos 1910, 1930". Além disso, Maria organiza eventos culturais para adultos e crianças.

Perguntaram sobre os limites da Zaandam, e ela explicou que Zaandam, originalmente, era uma municipalidade à parte. De fato, existiam 7 cidadezinhas Assendelft, Zaandam, Koogaan de Zaan, Krommenie, Westzaan, Zaandijk, Wormerveer - que se uniram oficialmente em 1974 numa única municipalidade, com o nome de Zaanstad: "Mas as pessoas não sentem que são habitantes de Zaanstad, elas ainda se identificam como moradores desses vilarejos. Vocês podem ver na fachada desse prédio, há 7 escudos que correspondem aos escudos desses vilarejos”.

Ela confirmou-lhes que Zaandam é uma área que tem sido "gentrificada" nos últimos tempos, acompanhando a alta dos preços em Amsterdã, mas que é, sobretudo, pela identidade de cidade operária que o lugar é conhecido. No passado, essa área foi famosa pela indústria de madeira (fabricavam barcos) e pela indústria alimentar: chocolate, arroz, papel; e pelos moinhos que, inicialmente, fabricavam farinha e processavam o cacau.

Por causa da indústria alimentar, chamavam essa área de "o celeiro da era dourada holandesa". A localização próxima a Amsterdã facilitava o recebimento de matéria prima e a distribuição dos produtos, tornando-a o principal polo produtor de alimento para a população holandesa. Nos anos 1970, imigrantes turcos, italianos e alguns espanhóis vieram para essa área para atuarem nas fábricas. Os espanhóis vieram, especialmente, para trabalhar em uma empresa de aço (Hillhover). Ela passou a ser conhecida por acolher imigrantes, especialmente pela imigração de turcos - e até hoje são muitos os restaurantes turcos que encontramos aqui. Mas, com a deslocalização e a concorrência da indústria chinesa, muitas fábricas foram fechadas. Também é uma área

professora. Sua família era judia ortodoxa, o que ela considerava sufocante. Irmã do escritor Jacob Israël de Haan, casou-se com Kees van Bruggen, socialista, em 1904. Foi com o marido para as Índias Orientais Holandesas e começou a escrever para os jornais de lá. Eles retornaram a Amsterdã em 1907, onde van Bruggen continuou escrevendo para várias publicações. O casal divorciou-se em 1917; ela mudou-se para Laren. Em 1920, ela casou-se com o historiador Aart Pit. Esse foi um casamento mais feliz, mas, após 1928, ela frequentemente sofria de depressão e passava algum tempo em hospitais psiquiátricos. Apesar de apoiar questões feministas, ela era cética em relação aos movimentos feministas de seu tempo. Da mesma forma, tinha uma relação desconfortável com o establishment literário, desenvolvendo seu próprio estilo de escrita e saindo das tradições literárias predominantes. Sua contribuição para o desenvolvimento da literatura holandesa só foi verdadeiramente reconhecida após sua morte. Van Bruggen morreu em Laren, aos 51 anos de idade, devido a uma overdose de pílulas para dormir.

Em: https://en.wikipedia.org/wiki/Carry_van_Bruggen [tradução CR] 
que concentrou muitos menonitas e amishes. E essas são pessoas que cuidam muito do meio ambiente.

Muitas casas em Zaandam são verdes; costuma se chamar de "verde Zaandam". Antigamente, quanto mais escuro fosse o verde, mais rico era o proprietário da casa, porque a tinta requeria mais pigmento, com um custo mais elevado. De onde veio essa ideia do verde? Maria não soube responder.

Pediram informações sobre a imigração de russos, pois elas haviam ficado curiosas com a área operária com ruas que levam nomes de autores e pensadores russos. Maria disse que nunca houve uma imigração de russos e que o bairro se deve à vinda do czar Peter. Contou-lhes que sua intenção era ficar incógnito, quase como um espião, para roubar os planos de construção de navios. Mas que, dado sua posição nobre e elevada, ele foi logo reconhecido.

Politicamente, a esquerda foi muito forte na área, especialmente nos vilarejos operários que existiam na outra margem do Zaan. Nos anos 1950, o Partido Comunista era hegemônico, recebendo a maioria dos votos, junto com o Partido Socialista. Marcus Bakker (1923-2009), um dos fundadores do PC na Holanda, nasceu e morreu em Zaandam, tendo aderido à Esquerda Verde em 1989. Maria explicou-lhes que a Esquerda Verde é mais forte em Amsterdam, entre indivíduos com mais educação, que podem pagar mais por produtos sustentáveis e que são mais caros. O Partido Socialista tem mais aderentes entre os trabalhadores com menor capital econômico, e não prioriza uma política voltada para o meio ambiente. A legislação de proteção tende a ser mais local, embora dependa do lugar onde se more. A reciclagem, por exemplo, é obrigatória e, dependendo de onde se mora, ela toma muito espaço, dado o tamanho dos containers. Esclarece que as leis federais são rígidas e que regulamentam desde o uso de lâmpadas até o de sacos plásticos.

Ela mostrou-lhes fotos de como se coletava o lixo no passado, quando não havia banheiros nas casas em Zaandam. "Nessa foto de 1927, vemos que se passava em cada casa para coletar as águas sujas. O sistema durou até os anos 1950. Imaginem o cheiro! [Os coletores] Eram chamados de "tumant schoenen" (sapatos Tumant). As fotos desses "tumant schoenen" mostram baldes cheios de excrementos, pendurados em uma vara levada nas costas e colocados em barcos que estacionavam nos piers/varandas das casas. Vemos também carroças e, mais para os anos 1950, camionetes, cumprindo a mesma função de recolher os excrementos e lixos domésticos. 
Apresentaram uma foto onde aparecia um cartaz regulando o uso dos containers coloridos. Ela sorriu, achando curioso que as pesquisadoras fotografassem latas de lixo, mas pacientemente foi lhes explicando o código das cores. O azul é para papel, o preto, para plástico e latinhas e o verde, para vegetais. O que não se inclui nessas categorias deve-se colocar em um container subterrâneo. Perguntaram pelo vermelho. "Esse eu não sei o que é", lhes disse, mostrando que o código não é inteiramente dominado pelos usuários.

Os números nos containers correspondem ao número da casa, "e, se alguém está caminhando na rua, não pode jogar o seu lixo ali”. Rindo, contou-lhes uma história que ilustra bem as confusões possíveis. Um dia desses, quando foi recolher os seus galões de lixo, eles não estavam onde os havia deixado. Bateu na vizinha para perguntar se ela não havia trocado os lixos: "Você tem o meu? Não! - ela respondeu. Finalmente descobri que tinha sido uma senhora mais velha que havia trocado os lixos. Bem, eu estava morando ali só há meio ano, então, foi bom para me integrar na nova vizinhança". Perguntaram sobre a rotina em relação ao lixo e resíduos, e Geike/Maria explicou:

\footnotetext{
"Os containers devem ser colocados na rua antes das $8 \mathrm{~h}$ da manhã, e retirados antes das $8 \mathrm{~h}$ da noite. Em dias de vento, isso pode ser um problema. Se os horários não são obedecidos, se se coloca na rua muito cedo, eles olham o endereço e recebe-se uma multa. $\mathrm{O}$ recolhimento de plástico ocorre uma vez por mês e se, por alguma razão se esquece, tem que se esperar pelo outro mês."
}

Maria acrescentou que, perto dos shoppings, há grandes containers e que ali se pode fazer o descarte de plástico em qualquer momento, gratuitamente. Os restos de árvores têm horários sazonais. No verão, os containers verdes são recolhidos toda as semanas e, no inverno, a cada 2 semanas. Para baterias, pilhas, lâmpadas, é preciso levar para pontos de recolhimento especiais, geralmente em shoppings e supermercados. Ela procura nos arquivos a foto de um grande cone de metal, e viram um adolescente jogando ali uma latinha. "Vocês podem achar isso engraçado, mas, em lugares de grande frequentação de jovens, eles instalaram também esses aparatos”, em uma espécie de campanha para que o descarte seja como esporte ou uma atividade lúdica.

Ela comentou outras sobre fotos das pesquisadoras: a de um container de construção, a de um para roupas do Exército de Salvação, outro, subterrâneo, para vidro, sem conter o riso com o inusitado das imagens: "ah, vocês, antropólogas...". Acha especialmente engraçada uma foto que fizeram de uma placa onde estão 
desenhadas ondas eletromagnéticas e que interpretaram como sendo proibido o uso do celular. "Não tem nada a ver com ondas!" ri. Elas justificaram sua interpretação, dizendo que na França, por exemplo, a ideia de alergia a ondas é forte e que há comunidades de pessoas que vivem em lugares onde é proibido ondas eletromagnéticas. Rindo, ela pediu para tirar uma foto das duas com essa fotografia. Esclareceu que se trata de um cartaz que anuncia que há vigilância entre vizinhos, através de um aplicativo, tal como existe também em cidades no Brasil.

Direcionaram sua conversa para perguntar sobre as condições de trabalho. Perguntamos pelo salário mínimo e sobre a escolarização dos lixeiros. Maria respondeu que a escolarização, de modo geral, é baixa. Falou que as pessoas que não podem trabalhar, por problemas mentais, por exemplo, recebem ajuda federal e devem dar em retorno um trabalho - que pode ser o de lixeiro. Mais adiante, na conversa, quando insistiram para saber se esse era um trabalho estigmatizado, disse que hoje o lixo já não cheira mal, com tantos instrumentos e produtos, e que eles ganham bem, que há estudantes que trabalham recolhendo lixo. O curioso é que eles são denominados "nopos", o que significa "free", mas não por ser um trabalho voluntário.

Maria falou-lhes de temas relacionados aos resíduos sólidos, que estão sendo muito discutidos atualmente nos Países Baixos. Conversaram, então, sobre a política neocolonial de enviar para a África e para a Ásia parte do lixo do país e acerca da política de aceitar lixos de outros países para serem processados (queimados) e gerarem energia. "Hoje", disse Maria, "os Países Baixos não têm como dar conta do lixo produzido aqui, que aumentou muito". Voltaram às fotos, e aos risos. Explicou-lhes sobre containers de companhias que recolhem metal e que são reciclados. Contou que há lugares onde se pode levar materiais para serem trocados por outros, comprados ou vendidos. Perguntaram sobre as lojas que vendem roupas usadas, ela informou-lhes onde havia uma e que esse tipo de loja está se tornando mais e mais popular. O cadeado que apareceu em alguns containers mostra que se trata de um container privado, de alguma loja, interditado ao acesso do público.

Zaandam foi pioneira também em práticas que hoje mereceriam o nome de sustentáveis: "Uma fábrica aqui reciclava jeans desde 1650, costumava fazer papel com tecidos velhos. Foi só a partir de 1870 que passaram a fazer papel da madeira. Claro que, na época, não se falava em reciclagem, era o único modo de se fazer papel.” 
O passado, porém, traz péssimas lembranças quando se trata do lixo. Além dos recolhedores de excrementos, ativos em Zaandam até meados do século XX, Maria falou-nos do perigo que existia nos anos 1980, 1990 com os "junkies”, em Amsterdã. "Podíamos nos ferir com as agulhas que jogavam em qualquer parte. Mas hoje não se vê mais isso, também porque o consumo de drogas mudou, não há mais tanta heroína”.

Atualmente, a municipalidade incentiva políticas de sustentabilidade, subsidiando empresas que reciclam, por exemplo, roupas ou móveis. Maria comentou as fotos que fizeram, dizendo que, atualmente, cada casa precisa ter quatro lixos diferentes: orgânico, papel, plástico e verde e ainda containers para vidros. São empresas comerciais que coletam os minicontainers em frente a cada casa. Em apartamentos é diferente, há containers no subsolo para onde são levados os "restos", o que não pode ser reciclado, como plástico, papel ou verde. A reciclagem existe há bastante tempo, mas essa separação obrigatória foi imposta há uns 2 anos. Também há uma taxação sobre os sacos plásticos de lixo que devem ser comprados na municipalidade - ou seja, quanto mais lixo se tem, mais sacolas se precisa e mais caro será.

Contou-lhes que, na cozinha do seu apartamento, há quatro latas de lixo. "Hoje, depois do café da manhã, eu joguei o plástico em uma e as migalhas de pão em outra. Esse lixo orgânico incomoda muito no verão, pois atrai as mosquinhas de frutas e outros insetos. E é malcheiroso. Não gosto de verão, por isso.” Esse lixo orgânico é recolhido uma vez por semana, às sextas-feiras, no seu caso. O plástico e o papel uma vez por mês, também na sexta, obedecendo os horários previstos. "Hoje pela manhã eu pensei que tinha que separar o tubo de pasta de dentes, mas estava apressada e coloquei tudo junto, sem ligar muito para o meio ambiente".

Outra foto, de um cinzeiro de metal com areia, incentiva a outro comentário: “Esses são novos. Os funcionários não podem fumar neste prédio, então saem. Também aqui temos todas essas latas de lixo. Me surpreende a quantidade de lixo que produzimos todos os dias".

O container subterrâneo é aberto com o cartão pessoal, a cada dois dias. Carmen, então, pergunta: “E se fazes algo errado, eles têm como saber, não?”. Nossa entrevistada responde, "Penso que sim", riu e acrescentou: “Alguém me contou que o container tem uma abertura lateral, assim, se uma mãe precisa trocar a fralda de um bebê e está na rua, ela tem como colocar a fralda suja por essa abertura. Tem um modo de burlar o 
sistema". Explicou ainda que uma das críticas recorrentes feitas pelos indivíduos é porque é que essa separação tem de ser feita individualmente, e não pela companhia.

Cornelia comentou que haviam visto a camareira do hotel saindo com uma sacola cheia de garrafas de plástico, e que Spencer já lhes havia dito que elas podem ser trocadas por dinheiro nos supermercados. Maria não pareceu familiarizada com isso “Curioso. Vi muito disso quando morei em Nova York, nos anos 1990. As senhoras chinesas andavam pela cidade empurrando um carrinho de supermercado e recolhendo pets que trocavam por fração de centavo. Mas aqui, nunca vi."

Falou que via muitas mudanças. "Esses dias, no supermercado, vi um homem que trouxe sua própria caneca de plástico [os supermercados oferecem café e chá de graça]. É uma ideia. Cada vez mais as pessoas trazem suas próprias sacolas para não precisar pagar por sacolas plásticas no supermercado.”

Agradeceram a entrevista, e ela, sempre rindo, disse que a conversa proporcionou "um jeito engraçado de olhar o meu próprio país, através das nossas fotos". E pediu-lhes: "Se vocês encontrarem alguma foto engraçada, me mandem pelo e-mail. E rindo muito, sentenciou: Uau, esses Dutch são loucos”.

\section{Vocês são as brasileiras?}

Após a entrevista e um rápido lanche, tinham que organizar a nossa agenda para o próximo dia, que implicaria seu deslocamento para Amsterdã, onde iram, mais uma vez, pesquisar no Museu da Cidade. Resolveram buscar orientações no Setor de Informações Turísticas, que poderia ser qualquer loja que tenha exposto os $3 \mathrm{X}$ do escudo de Amsterdã, conforme lhes havia explicado um homem em Zaanse Schans. Queriam saber se existia um sistema de passagens de trem, um cartão de desconto ou algo assim.

O jovem atendente, ao recebê-las, perguntou se eram turistas e por quanto tempo ficariam na cidade. Nem foi preciso explicar que não era propriamente turistas e que estavam desenvolvendo uma pesquisa para a Universidade, que lhes exigia deslocamentos por Amsterdã. O rapaz, rindo, perguntou-lhes se eram elas as brasileiras que estavam fazendo fotografias pela cidade, de lixos e placas. "Sim, mas como você sabe disso?", perguntaram. "Ah, me disseram que duas brasileiras estavam fazendo estranhas fotos na cidade. Vocês estão conhecidas por aqui", e continuou rindo. Ficaram incrédulas. Ele respondeu que as duas haviam entrevistado a bibliotecária e que teriam 
visto que Maria se divertia com algumas fotografias e com perguntas sobre os containers ou sobre o sentido de placas e anúncios, especialmente de uma foto de um celular. Perguntaram à Maria se naquela zona era proibido o uso de celular, e, rindo muito, ela esclareceu que significava que os vizinhos, naquela área, partilhavam de um APP de segurança que mantinha contato direto com a polícia, numa espécie de vigilância comunitária. Ao sair da loja, era a vez delas de rir, lembrando de Clifford Geertz e do famoso texto da Briga de galos em Bali, porque, em Zaandam, também sua invisibilidade era zero.

\section{O Museu da Cidade e as bitucas de cigarro}

Caminhar em Amsterdã é sempre ficar impressionado com a urbanística de uma cidade sobre canais, com ruas apinhadas de turistas, transeuntes e milhares de bicicletas. Deslocaram-se sempre atentas aos equipamentos de coleta de lixo.

No museu, mais uma vez, era possível acompanhar a cronologia histórica de formação da cidade a partir de diferentes setores e instalações, percorrendo da préhistória aos tempos atuais. Desta vez, compraram alguns livretos com informações históricas.

Na saída, depararam-se com um senhor negro, vestindo uma capa de chuva e recolhendo bitucas de cigarro com uma espécie de garra. Com um sinal de positivo com o dedo, pediram autorização para fotografar. Tentaram conversar sobre sua prática, mas ele lhes respondeu em uma língua nativa que não souberam reconhecer. Como há muitos imigrantes do Suriname, supuseram ser essa sua possível origem. Lembraram da informação de Spencer sobre a proibição do descarte da bituca de cigarro no chão. Mas, com a quantidade de bitucas com que se depararam nas ruas de Amsterdã, deu bem para concluir que os fumantes não se preocupam com o impacto ambiental deste ato. Concordando com um sorriso, Carmen filmou o ato da coleta com o instrumento. $\mathrm{O}$ coletor mostrou-lhes que juntava as bitucas com a vassoura ou as coletava com o aparelho. ${ }^{6}$

\footnotetext{
${ }^{6}$ Muitos fumantes ainda jogam suas bitucas em qualquer lugar depois que o cigarro acaba, esquecendo, ou sem conhecer, o risco ambiental que esse descarte incorreto representa. Segundo a Organização Mundial da Saúde (OMS), o número estimado de fumantes no mundo é de 1,6 bilhão. Essa enormidade de pessoas joga fora, de acordo com informações da Autoridade para as condições de trabalho (ACT), 7,7 bitucas de cigarro por dia. Ou seja, são cerca de 12,3 bilhões de bitucas descartadas diariamente. De acordo com relatório da NBC News, a bituca de cigarro polui mais o oceano do que as sacolas e canudos de plástico. E em relação aos outros tipos de lixo, a bituca de cigarro parece ser inofensiva quando
} 
De retorno a Zaandam, dedicaram-se a fotografar mais uma vez os aparelhos de reciclagem em um supermercado nas proximidades do hotel: reciclagem de lâmpadas, de garrafas pet e de vidro, de tampas de garrafas e outros coletores de resíduos. $\mathrm{Na}$ galeria da cidade, poucas lojas funcionando e muitas lojas fechadas.

lançada nas ruas e avenidas. O estrago que esse pequeno objeto causa, no entanto, é muito maior do que muita gente imagina.

Para se ter uma ideia, o tempo de decomposição de uma bituca de cigarro descartada incorretamente pode chegar a até cinco anos, principalmente se for jogada no asfalto, sem contar o fato de que ela contém mais de 4,7 mil substâncias tóxicas, o que prejudica o solo, contaminando rios e córregos. Essa relativa demora na decomposição deve-se ao fato de que $95 \%$ dos filtros de cigarros são compostos por acetato de celulose, de difícil degradação. https://www.ecycle.com.br/1894-bituca.html

Consulta em novembro 2019.

Iluminuras, Porto Alegre, v. 21, n. 55, p. 285-353, dezembro, 2020. 


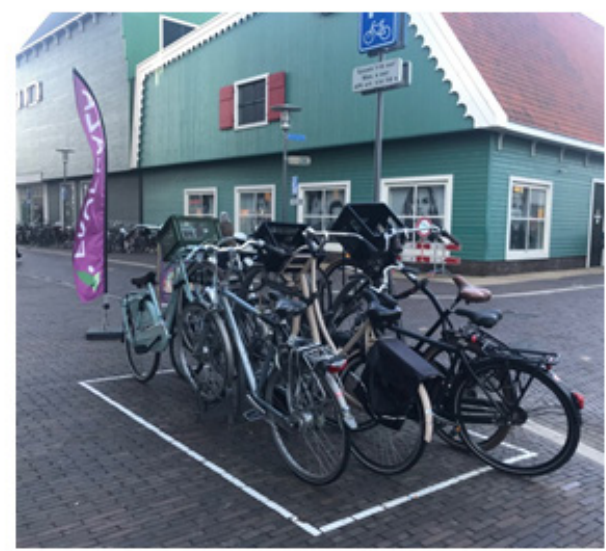

71

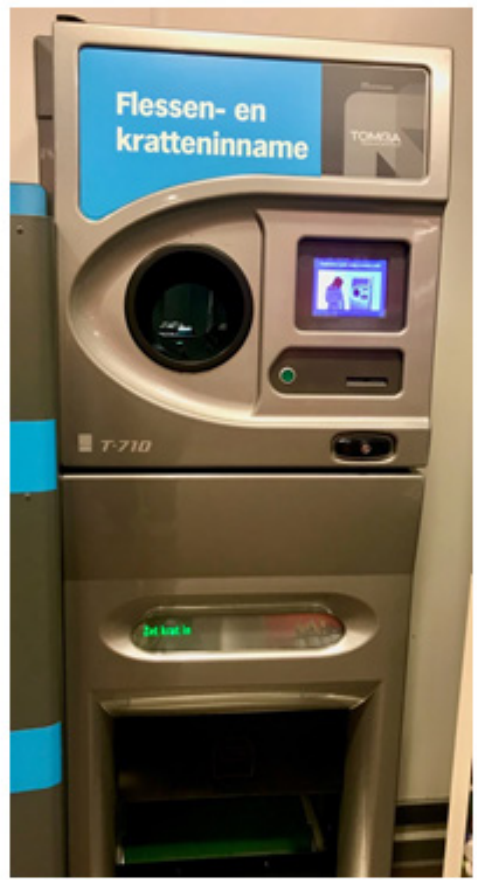

73

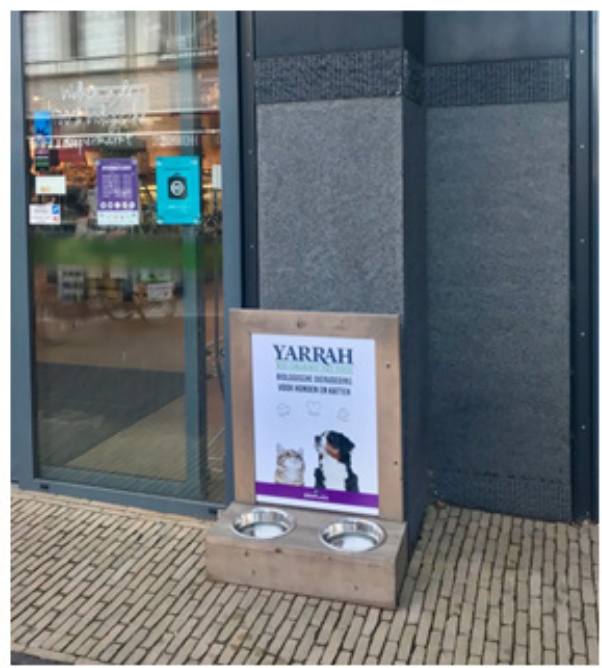

72

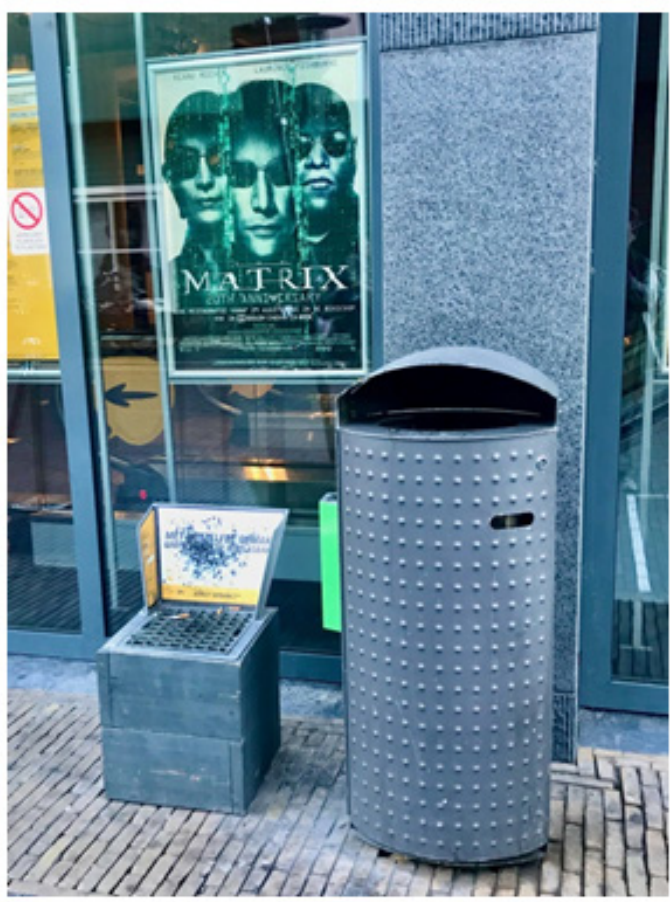

74 


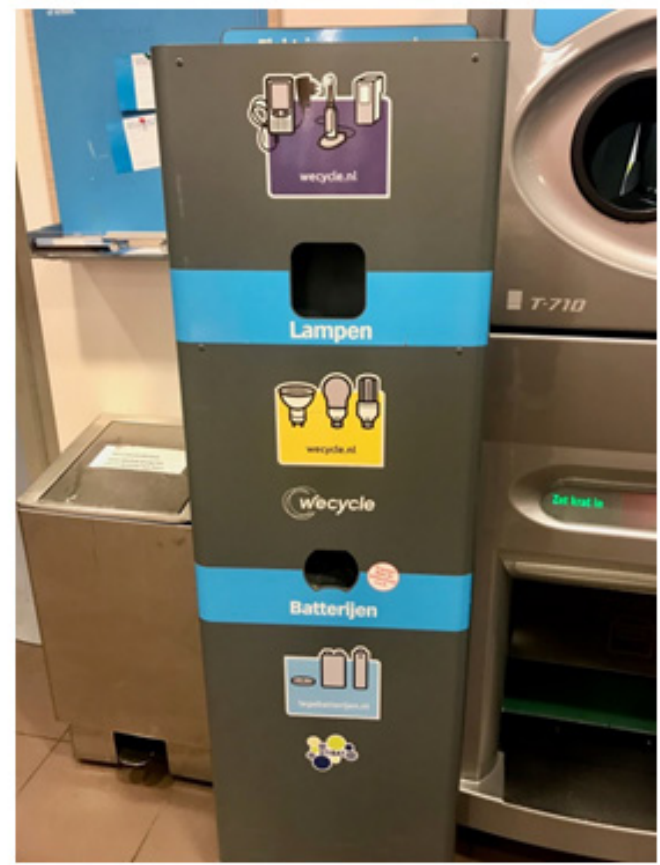

75

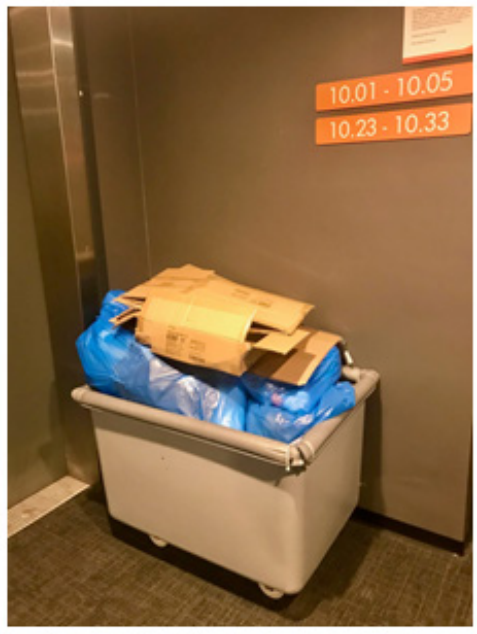

77

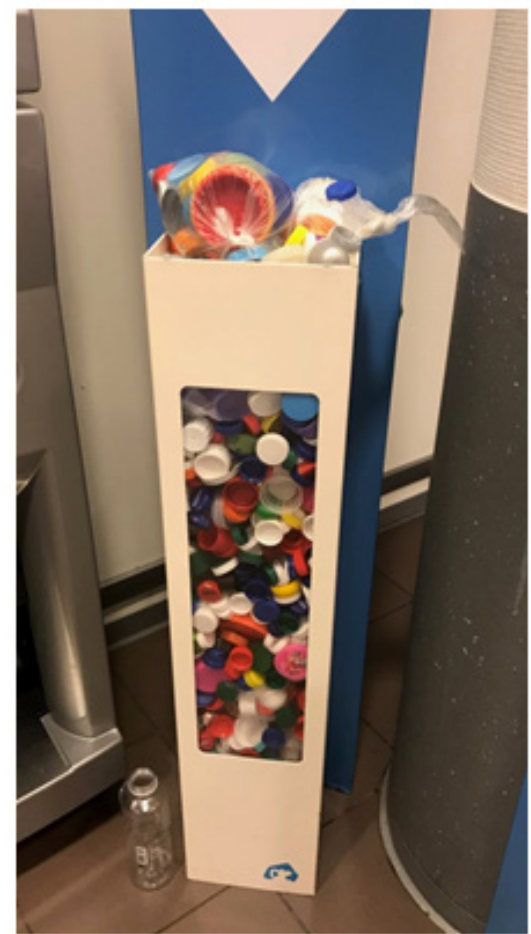

76

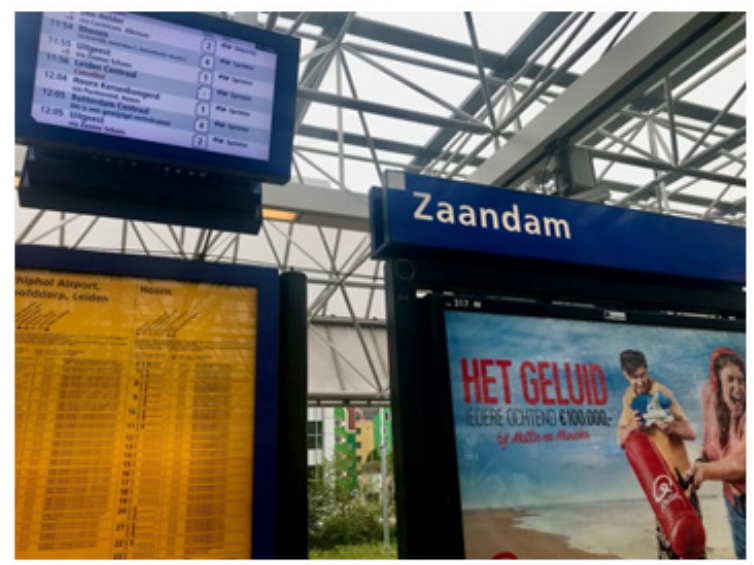

78

71 - Estacionamento próprio para bicicletas. Foto de Cornelia Eckert. Zaandam 6 de setembro 2019.

72 - Pote de água para pets. Idem

73 - Coletor de garrafas. Idem

74 - Lixeira e recipiente com areia para apagar cigarros. Idem

75 - Coletor de lâmpadas e baterias usadas. Idem (no caso, seria esse o crédito para a 5a imagem?)

76 - Coletor de plásticos. Idem

77 - Resíduos sólidos para reciclagem. Idem

78 - Estação de trem Zaandam. Idem

Iluminuras, Porto Alegre, v. 21, n. 55, p. 285-353, dezembro, 2020. 


\section{Nico e Vital, interlocutores privilegiados}

O dia 07 de setembro foi especial. Elas tinham duas entrevistas agendadas com conhecidos de longa data, mas em Amsterdã. Partiram cedo e caminharam longamente até chegar à residência de Nico Vink, no Oosterpark. Queriam chegar no horário combinado. Por isso, fizeram hora caminhando no parque e, como sempre, observando as latas de coleta de lixo.

Na hora combinada, chegaram na casa do professor, sociólogo aposentado, excolega e amigo de familiares seus. Ele mora em uma residência antiga, uma casa de dois pisos, porão e sótão, bem em frente ao parque.

Nico tem mais de 70 anos, talvez 75. Logo se dirigiu a elas em português, e ficaram impressionadas com o domínio da língua, apesar de tantos anos sem revisitar o Brasil. Conversaram sobre sua trajetória de formação escolar no Brasil e depois na Holanda. Nico, quando jovem, era padre e iniciou seus estudos na PUC, em Porto Alegre, conseguindo depois finalizar seu curso na UFRGS, onde conheceu uma geração de alunos, dos quais vários se tornaram professores ali. Defendeu sua tese de doutorado sobre telenovelas brasileiras na Holanda. Lembrou da importância do trabalho pioneiro de Ondina Leal, colega de mestrado delas, ainda muito citado. Lembrou do pai de Ondina, Prof. Fachel, ex-diretor do IFCH UFRGS, como alguém que o ajudou na universidade.

Após discutirem sobre a política no Brasil e na Holanda e seus arranjos neoliberais perversos e sobre a política científica e acadêmica, Nico anunciou que fariam um lanche. Foi quando elas conheceram seu companheiro, Vital, e passaram para uma outra peça da casa.

Em seguida, realizaram a entrevista sobre a seleção e tratamento de lixo doméstico e sua gestão no bairro, sobre os rejeitos. Relataram que, assim como eles, de modo geral, o citadino realiza a separação do lixo orgânico e do lixo reciclado. Neste caso, o material a ser reaproveitado consiste em embalagens, papel, tampas, vidros e plásticos. No caso desta unidade familiar, como possuem um pátio nos fundos com horta, o rejeito orgânico é tratado como compostagem. Elas perguntaram se esta prática tinha a ver com sua profissão, e ele, sorrindo, respondeu que não, que ele era agente funerário, que sua loja ficava ao lado da casa e que, por isso, para ele era fácil se dedicar-se à horta. 
As pesquisadoras seguiram perguntando sobre a reciclagem do lixo doméstico. Vital revelou-lhes as diversas práticas de separação do lixo, embalagens de papel, tampas, vidros, plásticos e orgânicos. Estes últimos são plantados para compostagem. Mostrou-lhes o pátio dos fundos, onde faz a compostagem. Carmen o acompanhou-o, calçando um tamanco típico, e Cornelia fotografou. Também indicou o único lixo de fato que havia para reciclar, um pequeno conteúdo em caixas de leite desmontadas. Os vidros ficavam acumulados no porão. Neste ponto, elas perguntaram sobre o destino desses resíduos, e Vital explicou que semanalmente desloca esse material a ser descartado em containers específicos da prefeitura. Perguntaram onde se encontravam, e ele se dispôs a acompanhá-las até os containers, localizados em outra quadra.

Elas seguiram Vital, filmando e fotografando, durante o rápido deslocamento até os coletores de lixo dessa zona. Na esquina da outra rua, encontraram os quatro grandes containers, cada um com uma tampa com cor diferente: branca, azul, amarela e laranja. Vital explicou que eram containers com um recipiente no subsolo. No de cor branca, a coleta é de têxtil. Na tampa azul são coletadas embalagens de papelão. No lixo de tampa laranja são coletados os plásticos e, no amarelo, os vidros. Filmaram e fotografaram, sempre entrevistando Vital. Carmen perguntou sobre o caminhão de coleta. Vital explicou que os mesmos passavam todos os dias. "E quanto aos orgânicos?", perguntou Carmen. Vital respondeu que eram depositados no container um pouco mais adiante, apontando para sua localização. Desta forma, os moradores da região que não praticavam a compostagem, precisavam trazer seus lixos até esse local.

Carmen observava uma lata de cerveja, jogada ao lado de um coletor, e juntou a latinha. Perguntou, então, onde depositar esse resíduo. Vital, rindo muito, disse que não havia coletor algum para o objeto e que o mesmo deveria ser descartado junto com os orgânicos. Incrédula, Carmen explicou que no Brasil esse descarte tem muito valor para a reciclagem. Vital concordou, dizendo que nos Estados Unidos se passa o mesmo, mas que não havia em Amsterdã esse valor. Carmen levou a lata até o container do lixo orgânico, enquanto Vital, rindo, disse que Carmen estava limpando a Holanda e Cornelia seguia filmando. Olhando para a câmera, Vital perguntou se haviam ido visitar a Green Energy Factory. Anotaram a sugestão, mas justificaram seu curto período de campo para tal empreendimento. 
Em suas pesquisas na internet, no site https://amsterdameconomicboard.com/en/nieuws/groente-fruit-en-tuinafval-het-beginvan-iets-moois, encontraram este empreendimento relacionado a uma companhia Meerlanden de fonte de energia, criada em 2010, que produz 55.000 toneladas de resíduos orgânicos anualmente. ${ }^{7}$

Despediram-se de Vital para nos dirigiram-se ao seu próximo encontro.

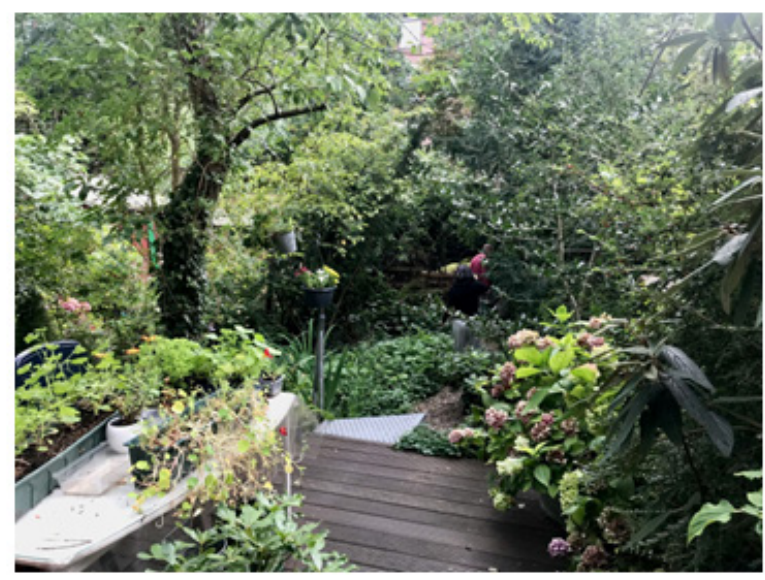

79

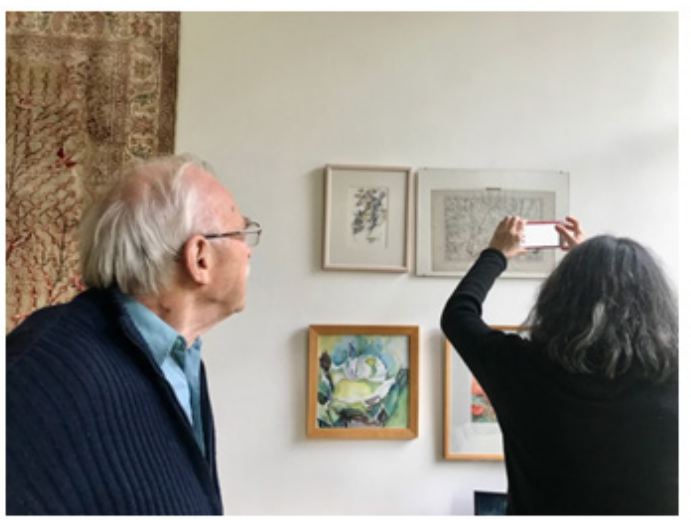

81

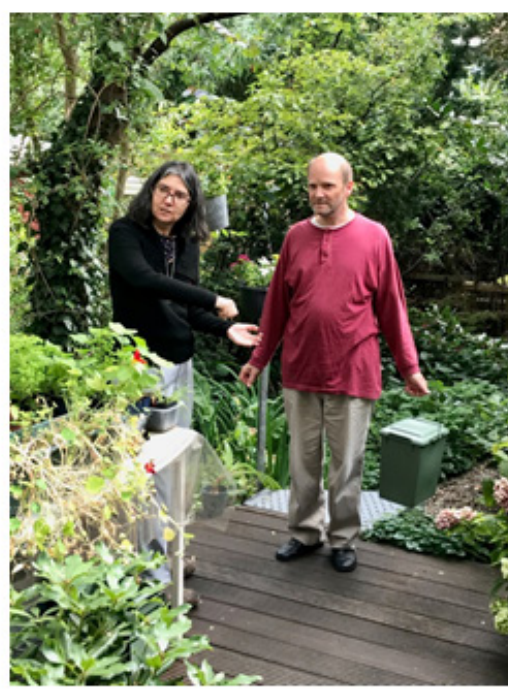

80

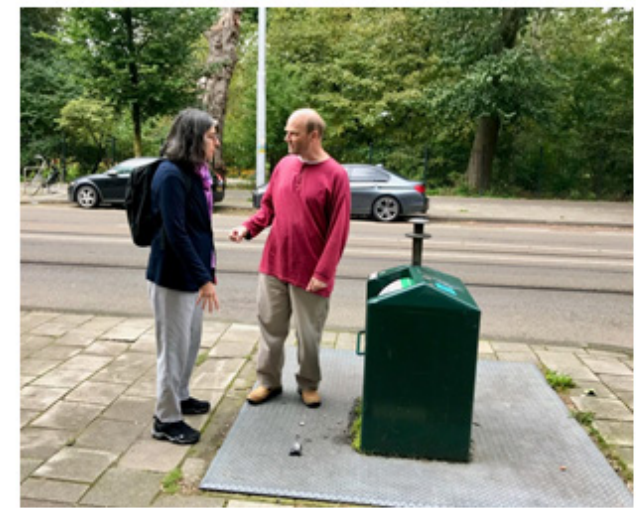

82

\footnotetext{
${ }^{7}$ A fábrica processa resíduos de hortaliças, frutas e jardins em cinco etapas, cada uma das quais dá origem a uma produção. Um digestor especial, fabricado na Suíça, processa 53.000 toneladas de resíduos orgânicos das 55.000 produzidas. Sessenta por cento do lixo orgânico é usado na obtenção do biogás, que é purificado para criar 'gás verde'. Isso é usado para alimentar mais da metade de todos os veículos da Meerlanden; o restante chega às residências e indústrias da região. $\mathrm{O} \mathrm{CO} 2$ é capturado a partir do biogás e entregue a várias empresas de horticultura com efeito de estufa, que o utilizam como estimulador de crescimento. Recentemente, a Meerlanden também começou a aplicar uma técnica para extrair óleo de cascas de frutas cítricas, produzindo um combustível que é usado em vez de diesel nos equipamentos de controle de ervas daninhas da Meerlanden.
} 


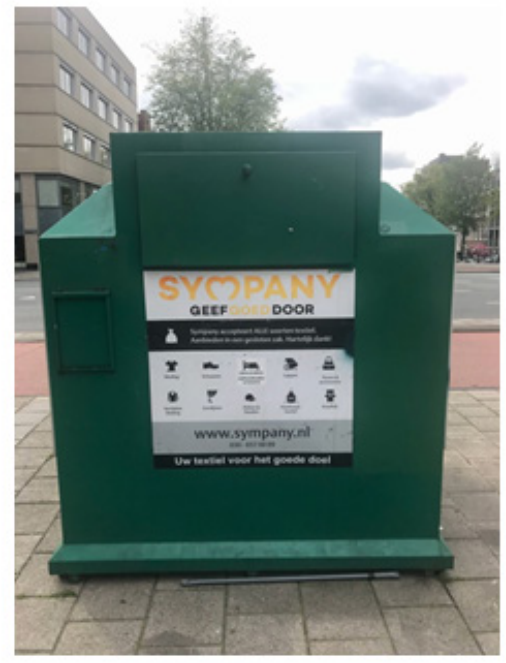

83

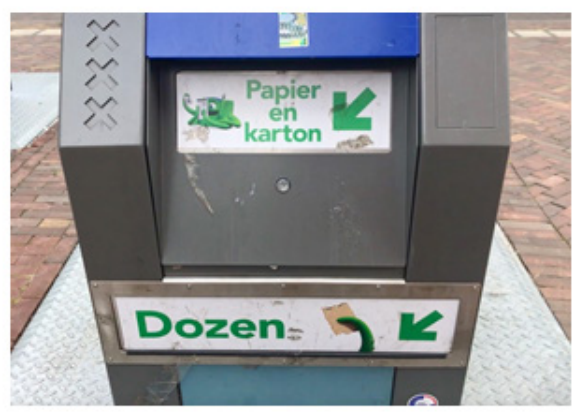

85

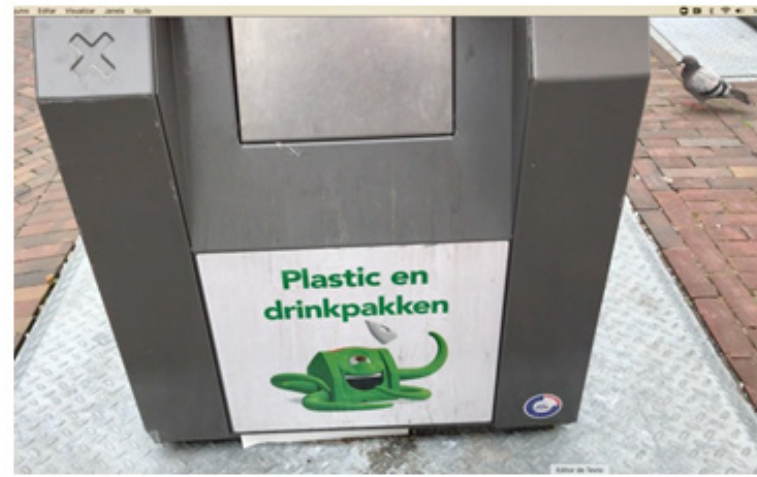

84

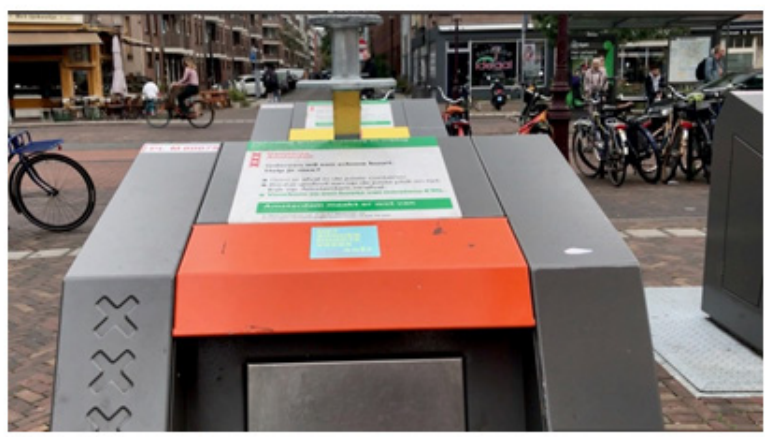

86

79 - Visitamos/Visita ao pátio dos fundos do nosso entrevistado, para conhecer o sistema de compostagem. Foto Cornelia Eckert, Amsterdã 7 de setembro 2019.

80 - Idem

81 - Nosso anfitrião, Nico, mostra-nos quadros com temas ambientais. Idem.

82 - Vital nos leva na esquina para conhecer os depósitos de resíduos sólidos. Idem

83 - Depósito de resíduos sólidos para os moradores do quarteirão. Idem.

84 - Idem

85 - Idem

86 - Idem

\section{Um café com Marjo}

A segunda entrevista, no final da tarde, foi uma mistura de happy hour, reunião de intercâmbio e entrevista. Não foi possível gravar sua fala com a Profa. Theije, devido ao barulho no ambiente, mas, uma vez mais, reforçou aspectos culturais que contrastam a vida cotidiana em Amsterdã com a da periferia, como Zaandam. 
Quanto ao seu lixo doméstico, Marjo repetiu a afirmativa de Vital relativa à prática da separação dos rejeitos por seleção quanto ao gênero da matéria e o seguimento as regras estabelecidas pela política de despacho com a utilização do cartão de uso individual em cada condomínio. Lembrou que a multa era expressiva e que a tendência era o cumprimento das regras.

\section{A cidade festival}

Dia 8 de setembro. Chegara o grande dia do festival Zaanse UITmarkt www.zaanseuitmarkt.nl. Ao longo da semana, Cornelia e Carmen observaram os diversos Outdoors e cartazes convidando para o evento. Spencer e Maria as haviam alertado para não perderem esta ocasião, em que a toda cidade se reunia em atividades culturais, alimentícias ou simples sociabilidade lúdica. Curiosas para saberem se conseguiriam dados para sua pesquisa, buscaram o local do encontro. Um amplo espaço tomado de barracas, cada uma com uma função, além do parque e espaços para alimentação.

Muitas pessoas estavam fantasiadas, e o ambiente era descontraído. Elas percorreram os diversos barracos, cada um com uma proposta diferente, mas todos promovendo atividades culturais. Algumas delas eram voltadas para as crianças, outras, para adultos, como o jogo de bingo. Duas barracas chamaram sua atenção. Uma, montada pela prefeitura, expondo as publicações produzidas pela municipalidade e muitas caixas de fotografias antigas reproduzidas para a venda. Outra barraca era dedicada a divulgar o Museu Zaan, com distribuição de folders e informações. Nesta barraca, conversaram com as recepcionistas, que lhes cederam alguns folders.

$\mathrm{Na}$ barraca da prefeitura, encontraram a sua interlocutora Maria, que lhes apresentou para um rapaz e explicou para ele, em dutch, quem eram elas. Também aproveitaram para conferir os livros e fotos antigas na barraca. Com preço expressivo para suas condições, não adquiriram nenhum, mas lhes permitiram fotografar algumas capas e postais.

$\mathrm{Na}$ barraca sobre o atelier de Monet, conversaram com a atendente para entender por que estava sempre fechado. Esclareceu-lhes sobre o horário de funcionamento, e elas anotaram. Em outra barraca, um rapaz convidava para utilizarem uma bicicleta que geraria energia para o funcionamento de um liquidificador que faria sucos. Carmen 
aceitou o desafio. Cornelia filmou e perguntou o nome do rapaz, Eric. Ele colocou banana e um suco em um liquidificador, aparelho que ele havia adaptado à bicicleta. Carmen pedalou, dando energia para o liquidificador funcionar e perguntou sobre as práticas de lixo. O rapaz explicou rapidamente que havia política para o lixo e que praticava o processo seletivo, mas que havia excesso de consumo e por isso a grande quantidade de lixo. Após oferecer-lhes o suco em um copo de papel, descartou o recipiente separadamente do lixo orgânico, em um saco preto.

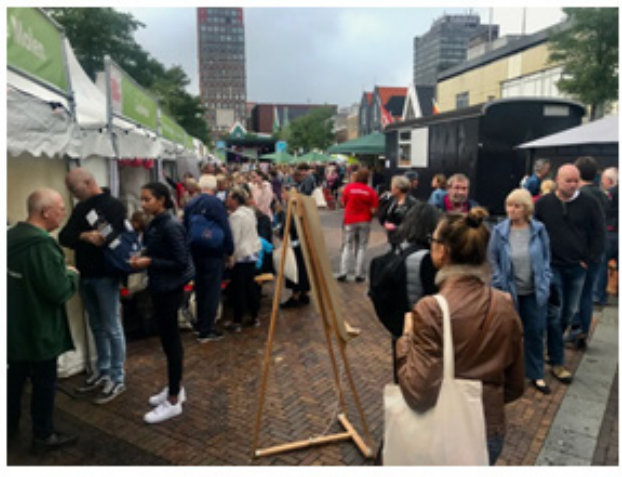

87

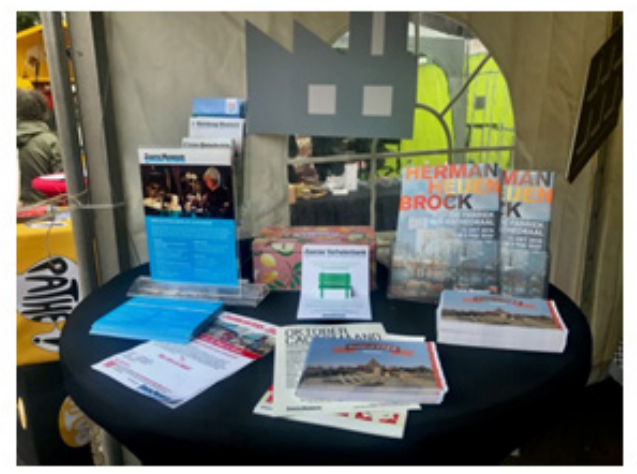

89

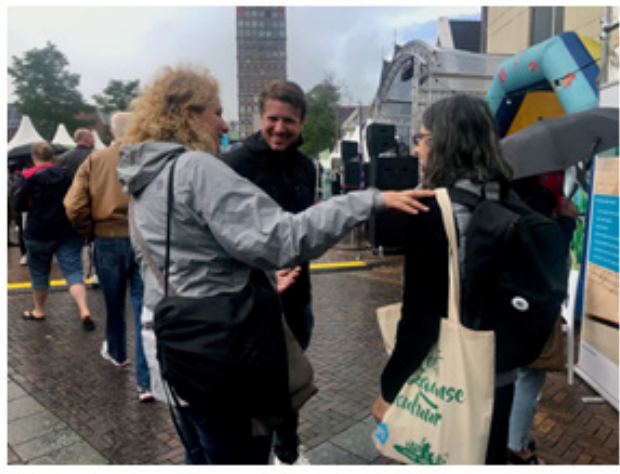

88

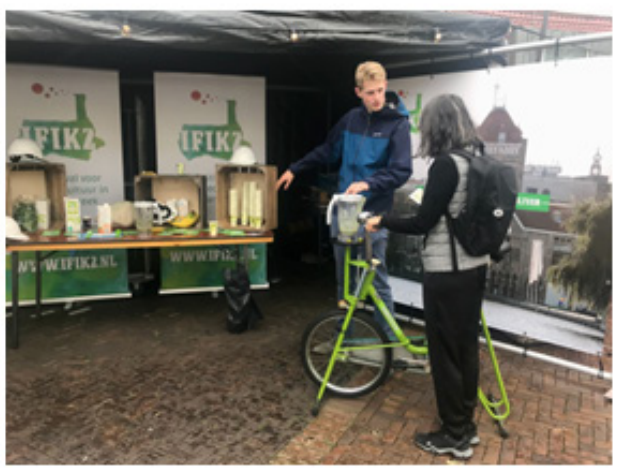

90 


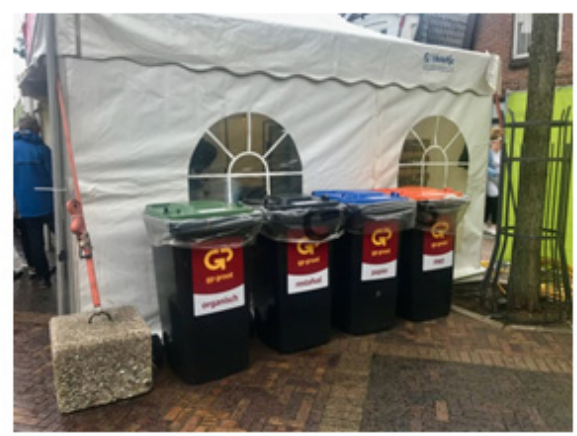

91

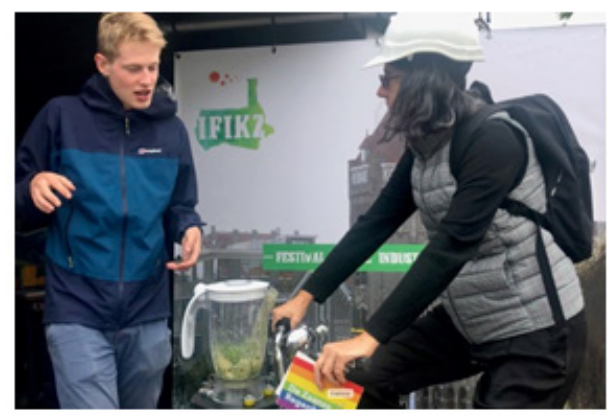

93

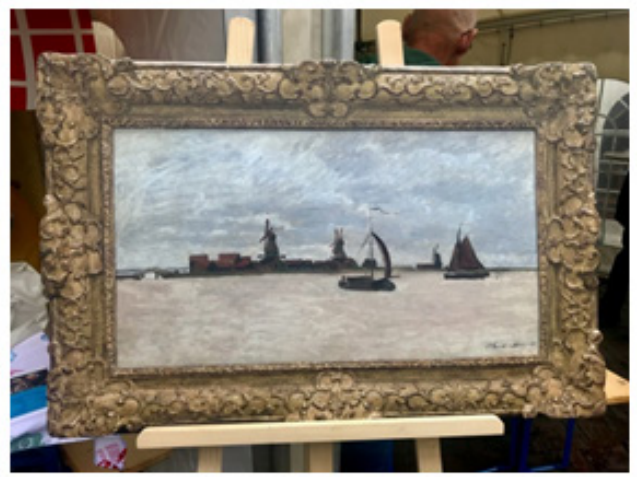

95

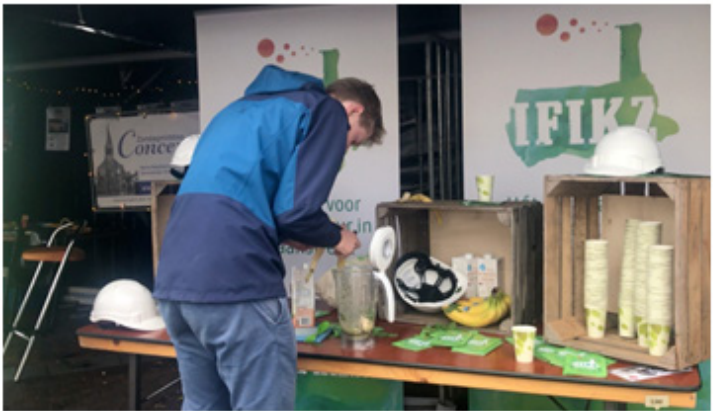

92

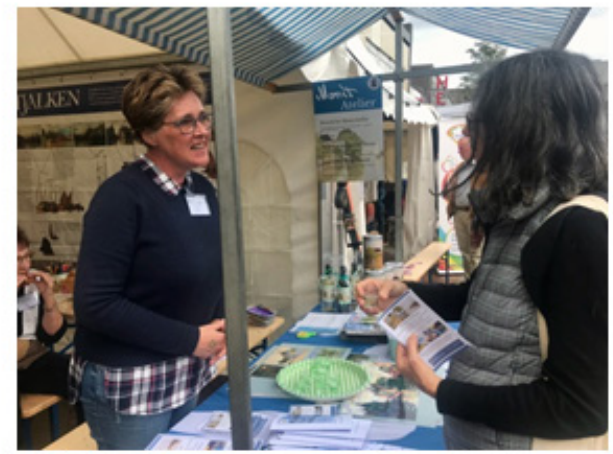

94

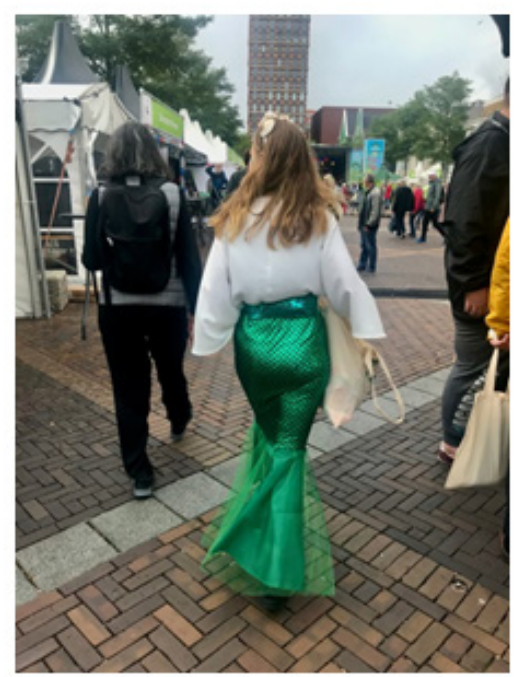

96 


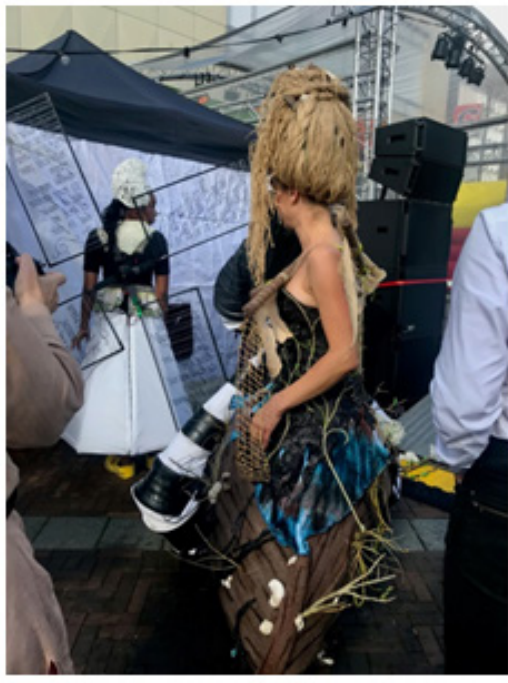

97

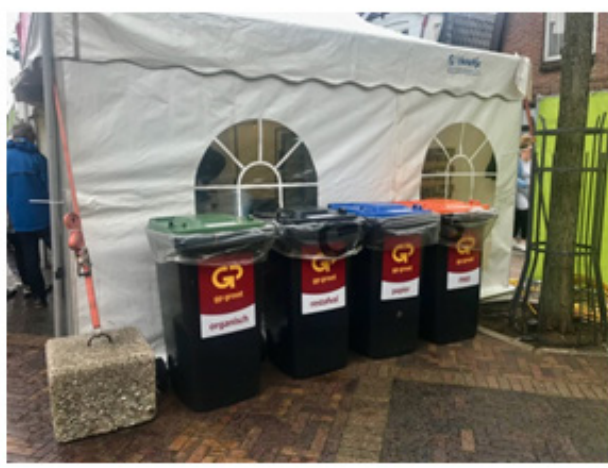

99

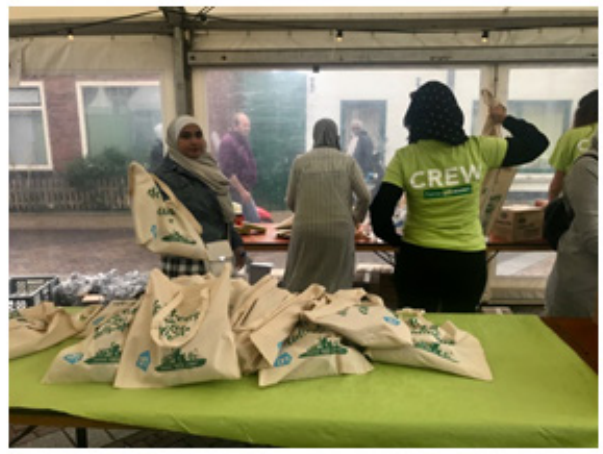

101

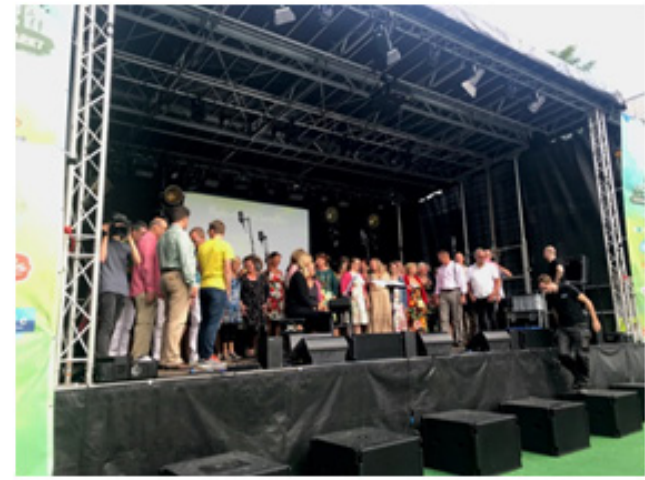

98

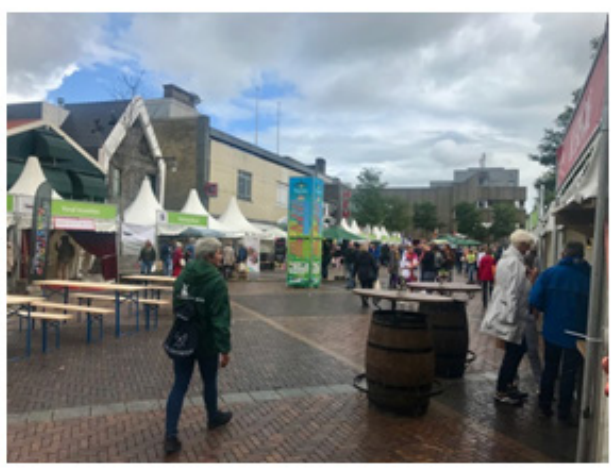

100

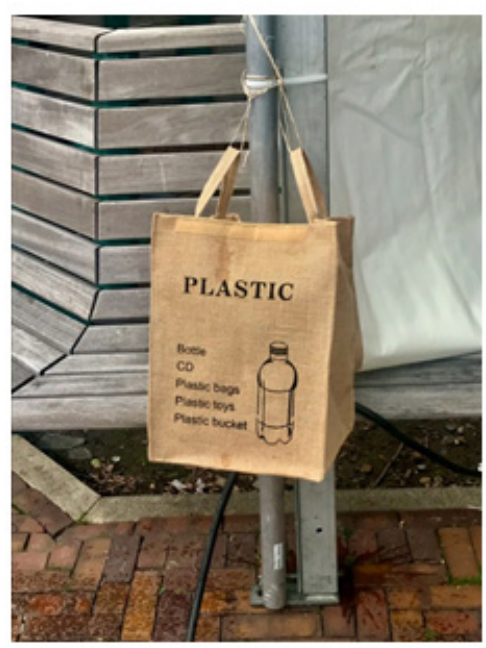

101 


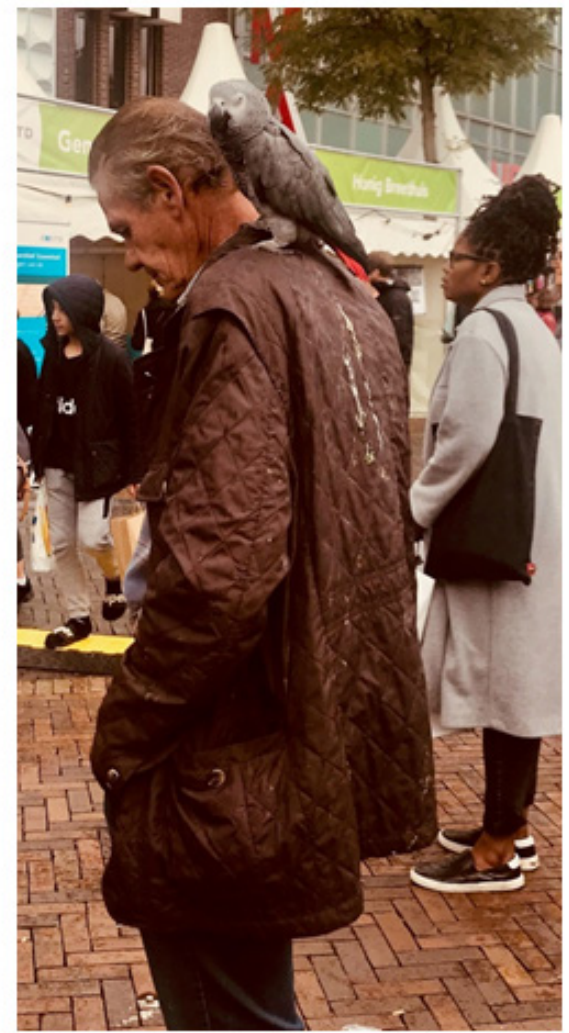

103

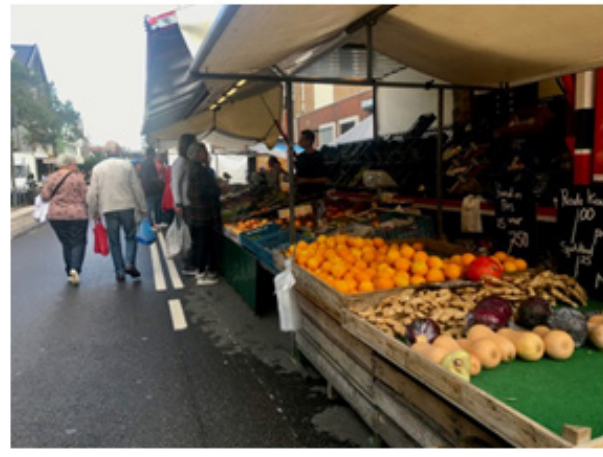

104

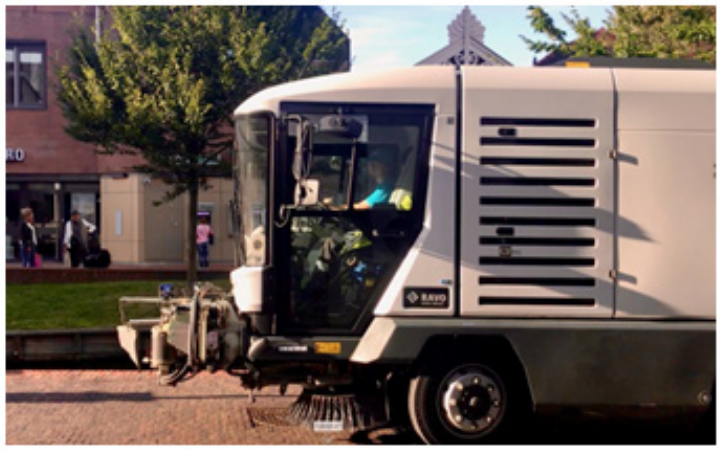

105

87 - Zaanse Mark, encontro cultural no centro de Zaandam, promovido pela Prefeitura Municipal. Foto de Cornelia Eckert. Zaandam, 08 setembro 2020.

88 - Encontro com Maria, nossa interlocutora. Idem.

89 - Feira de livros. Idem.

90 - Carmen conversa com Eric, atendente em uma barraca que promovia cultura industrial do Zaanstreek. Idem (Conversa entre Carmen e Eric, atendente em...)

91 - Idem

92 - Idem

93 - Idem

94 - A atendente do Museu Van Gogh nos dá orientações. Idem (Orientações dadas pela atendente do Museu Van Gogh) 
95 - Réplica de quadro de Van Gogh. Idem

96 - Desfile de fantasias com produtos recicláveis. Idem.

97 - Idem

98 - Apresentação de corais. Idem.

99 - Containers de coleta de descartes. Idem

100 - Fim de festa. Idem.

101 - Distribuição de brindes. Idem.

102 - Festa com forte discurso ambiental. Idem

103 - Alguns personagens incríveis. Idem.

104 - Retorno pela feira livre. Idem

105 - Caminhão de limpeza de ruas. Idem.

Elas realizaram várias fotografias e pesquisaram as imagens expostas no ateliê da prefeitura. O festival foi recheado de shows no palco principal: de teatro, de performances, de concurso de fantasia, de músicas com instrumentos exóticos, de dança com bandeira brasileira, em que tocavam um berimbau, e jogos, entre outras propostas. Tudo muito bem organizado, com uma meteorologia instável, que variava entre sol e chuviscos.

No retorno, as duas fizeram um caminho diferente, encontrando a feira de frutas e comida da cidade já no seu fechamento. As caixas vazias e os lixos estavam sendo coletados pelos feirantes. Com um sinal, pediram consentimento e filmaram rapidamente.

Ainda na volta, encontraram Spencer. Conversaram sobre o evento e sobre o acúmulo de sujeira no sábado por ser um dia de muito movimento. De fato, o comércio estava muito concorrido. No coreto, uma banda de jazz animava os transeuntes. A orquestra competia com um senhor que tocava o aparelho de realejo, objetivando recolher moedas.

Continuando a conversa com Spencer, perguntaram se ele não teria folga no sábado. Ele respondeu que nem no sábado nem no domingo, pois são dias de muito lixo. O canal estava limpo, mas não raro apareciam papeis, garrafas, e mesmo balão flutuando, e logo Spencer coletava o material.

No final da tarde, passou um caminhão da firma ZNSTD, lavando a calçada, acontecimento que gravamos sem problemas. Para passar com o pequeno caminhão, o motorista desceu para baixar os pilares de proteção que são reclináveis, de modo a 
poder fazer o retorno e, mais uma vez, percorrer a avenida principal com os lavadores acionados. A cidade voltava a ser tomada pelo sossego.

\section{O rio Zaan}

Mais um dia de observação. Após visitarem uma velha igreja, Doopsgezinde Vermaning Zaandam, transformada em centro cultural, e fotografarem, o dia permitiu que realizassem o percurso com o catamarã pelo rio Zaan, de $10 \mathrm{Km}$. O ferryboat partiu às $14 \mathrm{~h}$ em direção ao parque Zaanse Schans, região dos moinhos, que já mencionada.

Impressionou a limpeza da água e a grande quantidade de pontes que o barco ultrapassou. Algumas pontes precisavam serem içadas, sob outras, o barco passou com folga. Nas margens, muitos edifícios se sucediam, alguns com trapiche para acesso a pequenos barcos. Mas a paisagem é, sobretudo, dominada por grandes indústrias. Alguns prédios antigos, outros, modernos e de grandes proporções. $\mathrm{O}$ destaque entre as empresas é para a de chocolate, que ocupa um imenso território. Esta passagem anuncia a proximidade ao parque e a vista dos moinhos.

A zona industrial era entrecortada por pequenos povoados com casas típicas. Com a vista privilegiada, foi possível fotografar à vontade a paisagem idílica. Acostumadas com a relação indústria-água poluída, o maior impacto era testemunhar esta proximidade entre a área industrial e a cristalinidade das águas. Em Zaanse Schans, o barco fez uma parada para pegar turistas e começar o caminho do retorno.

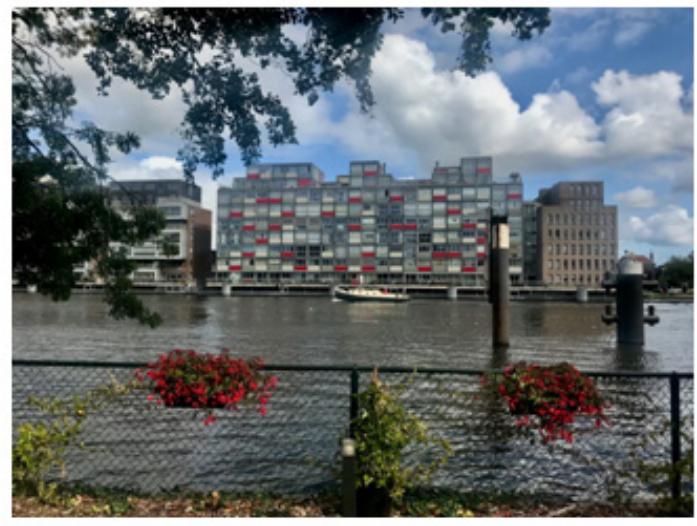

106

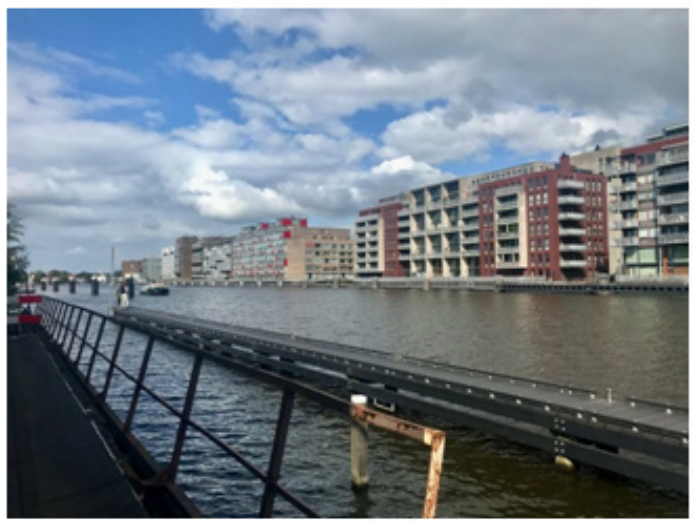

107 


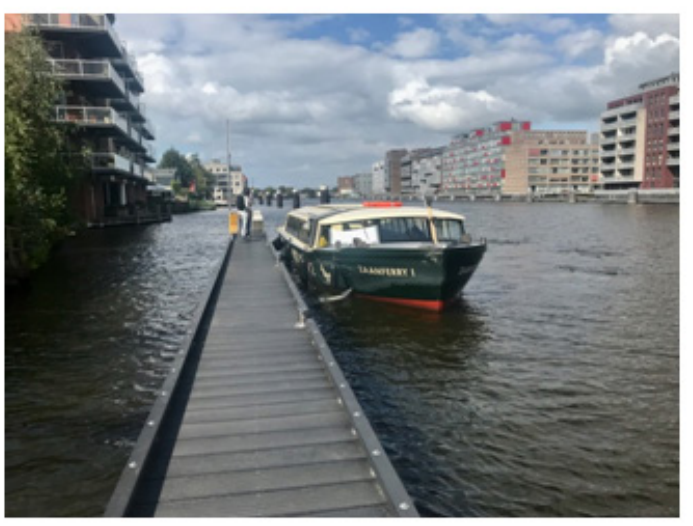

108

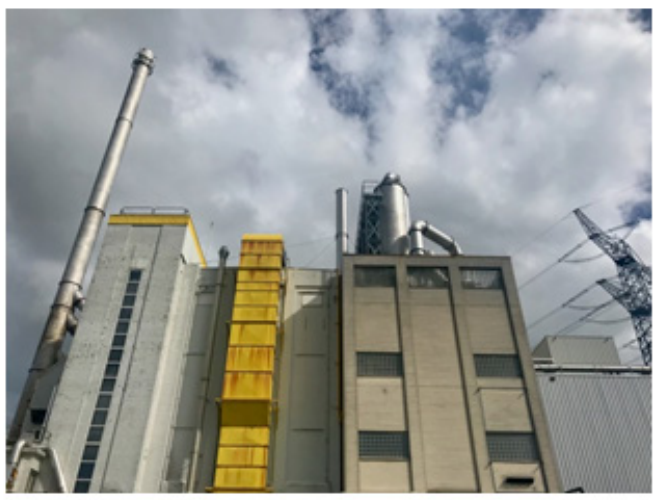

110

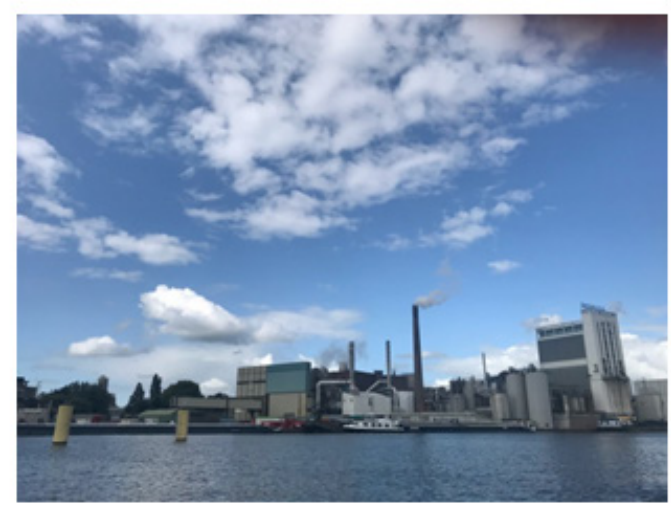

112

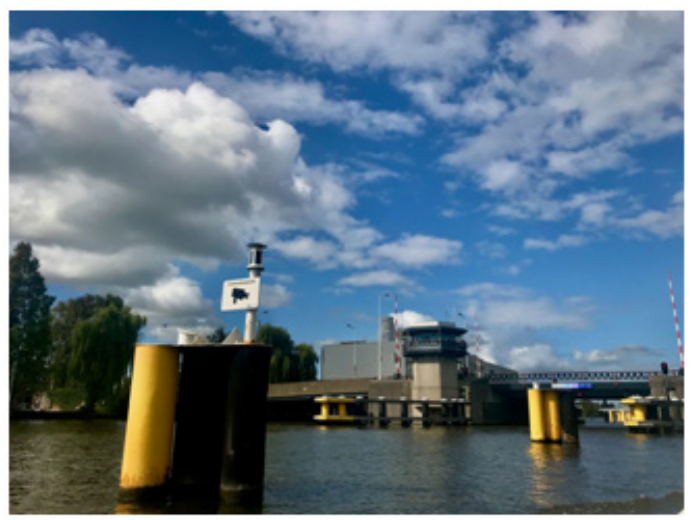

109

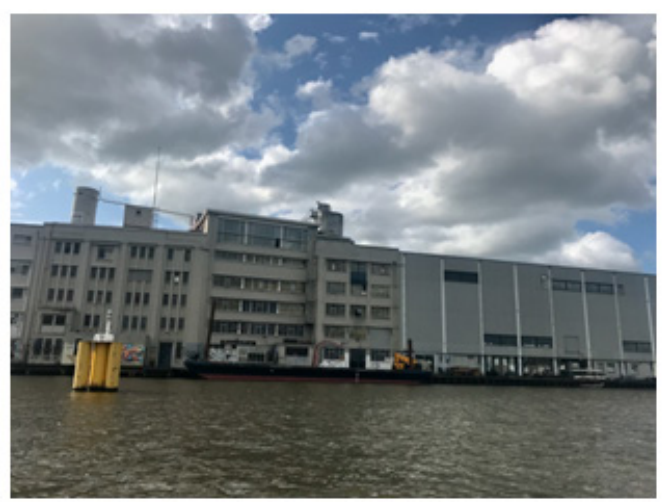

111

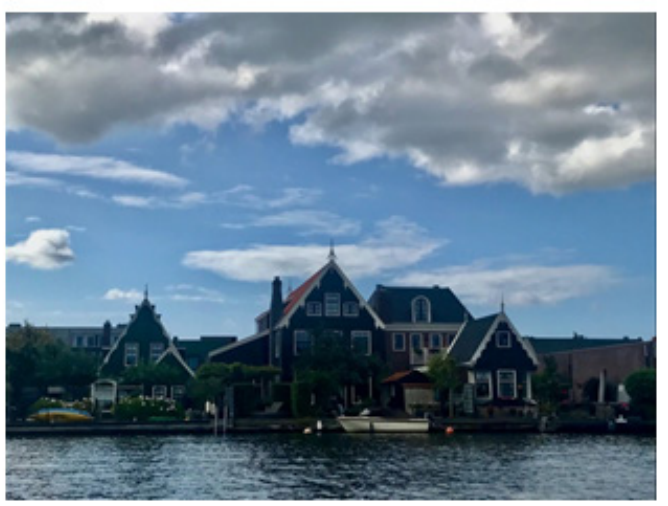

113 


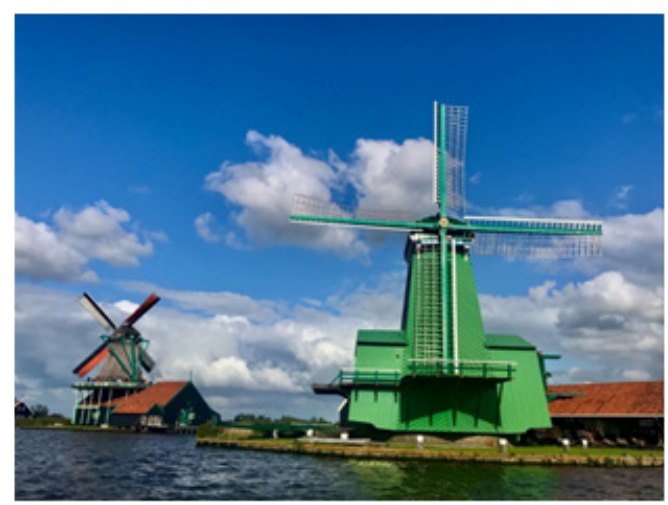

114

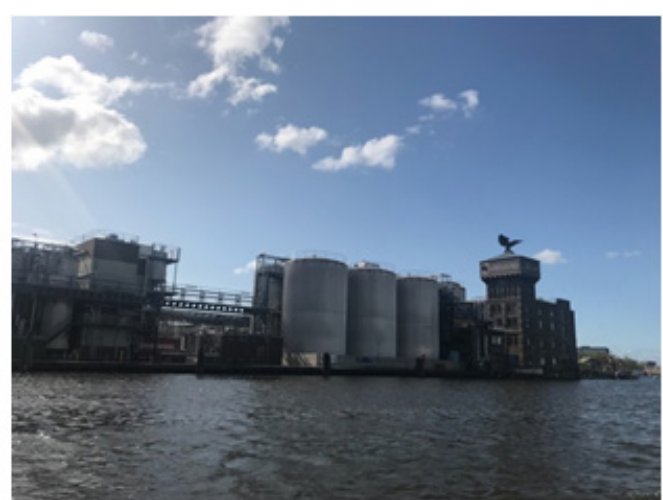

115

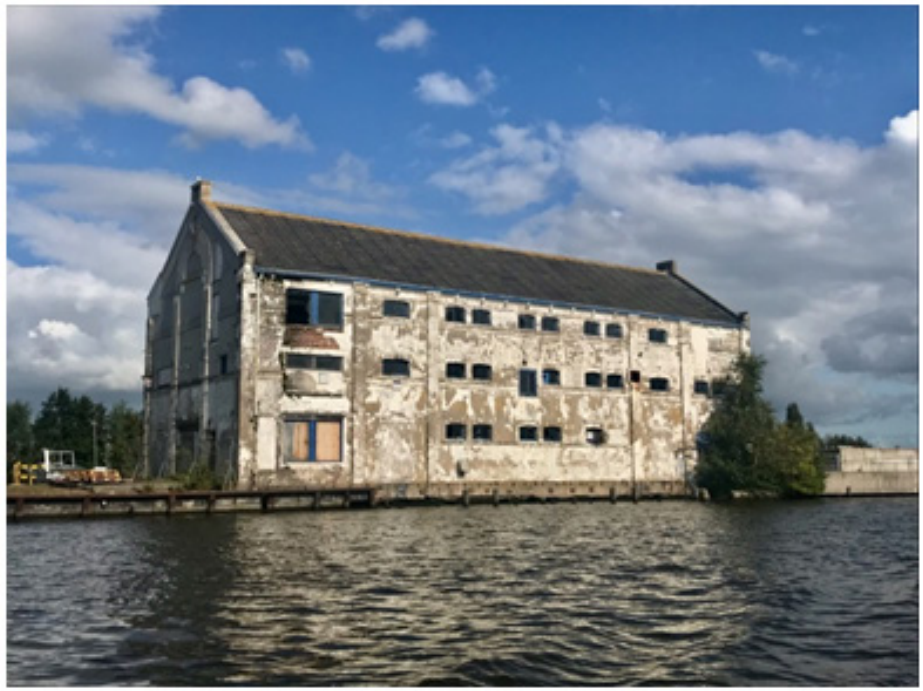

116

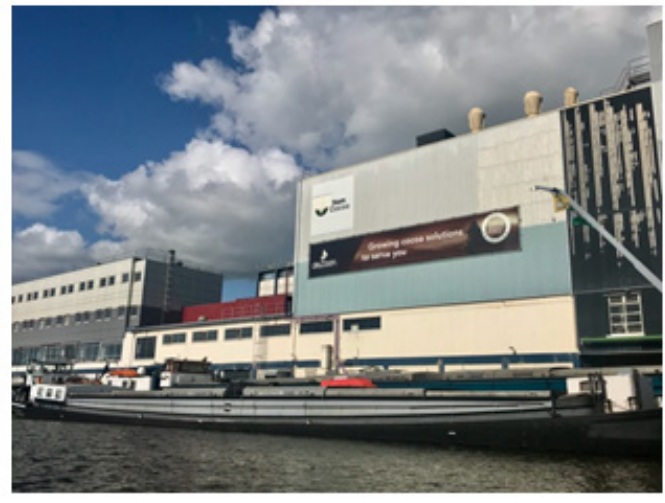

117

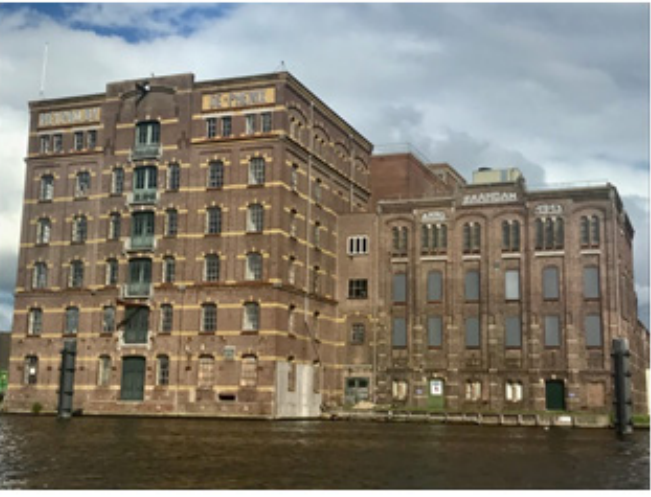

118

106 - Esperando a embarcação. Apreciando o rio Zaan. Foto de Cornelia Eckert. Zaandam, 9 de setembro 2019.

107 - Idem

108 - Embarque no camaratã. Idem. 
109 - Ponte elevadiça. Idem.

110 - Complexo industrial à beira do rio Zaan. Impressionante limpeza da água. Idem

111 - Predomínio de indústrias de chocolate. Idem

112 - Complexo Industrial

113 - Destino do passeio, antes do retorno, Zaanse Schans. Idem

114 - Zaanse Schans. Idem

115 - Complexo Industrial. Idem

116 - Prédio abandonado, antiga fábrica. Idem

117 - Indústria do chocolate. Idem.

118 - Antiga fábrica. Prédio fechado. Idem

\section{Conferindo os lixos}

Os dois próximos dias foram dedicados à Etnografia de Rua para filmar e fotografar o sistema de coleta de resíduos orgânicos e sólidos. Foram longas caminhadas, em geral iniciadas na avenida central do canal Gedempte Gracht (Canal Silenciado).

Em um dos dias, voltaram a atravessar a ponte principal e caminharam por um bairro menos revitalizado, com alguns prédios históricos como igreja, fórum e parque de diversões e algumas ruelas, um pequeno comércio, mas também com longas ruas de condomínios ora com casas geminadas e ora com edifícios populares. No tocante às casas, os contêineres que coletam o lixo, de modo geral, são dois, um de tampa preta e outro de tampa azul. Em alguns casos há também um container verde. Abriram as latas para conferir o conteúdo. Encontraram no lixo de cor preta os restos orgânicos, nas demais latas, em geral, papelões e plásticos. Em alguns containers, entretanto, havia material misturado como papel com terra e folhas. Talvez um pequeno descuido sujeito a multas. Nos edifícios há presença de containers acessíveis com os cartões e códigos, no mesmo esquema descrito por Vital na entrevista realizada em Amsterdã. Fotografaram, como sempre, para o seu acervo de pesquisa.

\section{Desperdício nunca mais}

Em outra caminhada, observaram alguns coletores de resíduos que ainda não haviam visto. Um deles estava recolhendo as pontas de cigarro com o gancho de coleta. Tentaram se comunicar, mas não conseguiram se fazer entender. Mais uma vez, a língua como barreira. Com gestos, pediram autorização para fotografar, evitando captar o seu 
rosto. As pesquisadoras seguiram seu percurso, observando, mais uma vez, pessoas fumando próximas às latas de coleta de lixo para apagarem seus cigarros em um dispositivo próprio para isso e para a coleta do cigarro apagado.

No caminho de retorno, outra vez encontraram coletores trocando os sacos das latas dispostas ao longo da rua. Agora não era Spencer, e sim um outro senhor que estava realizando o serviço. Também observaram que, logo mais adiante, uma mulher fazia a mesma tarefa. Estavam vestidos de uniforme verde bastante chamativo.

Nesta caminhada, concentraram seus esforços em fotografar e filmar a atividade do caminhão de lixo da empresa RENEWI. No caminhão estava impresso em letras garrafais WASTE NO MORE. Já haviam pesquisado sobre esta empresa e, inclusive, feito sua inscrição para visitar e solicitar uma entrevista. Tudo isto através do site da empresa. Mas não obtiveram um retorno.

RENEWI é o Centro de reciclagem em Amsterdã, Países Baixos. No seu site https://www.renewi.com/nl-nl, anuncia que o objetivo da companhia é oferecer uma nova vida para materiais usados e oferece seus serviços a empresas e particulares, tendo por lema: Segurança, Sustentabilidade e Renovação. Tem por foco uma economia próspera a ser alcançada pela reciclagem de resíduos e sua possível reutilização. Argumenta ter experiência internacional em vasta gama de produtos, reciclando uma média de 14 milhões de toneladas de resíduos coletados entre 2 milhões de residências, com $89 \%$ de produtos reciclados e reutilizados, evitando a emissão anual de 3 milhões de toneladas de $\mathrm{CO} 2$.

O site fala em oito mil trabalhadores, alcançando 200 locais de atividades. Uma aba do site apresenta o perfil destes trabalhadores, desde altos executivos - homens e mulheres - a coletores de lixo. A partir de uma fotografia do(a) trabalhador(a), é possível acessar uma pequena biografia com sua atividade principal na empresa, local de atuação, seus gostos pessoais, realizações e projetos, conforme https://careers.renewi.com/nl-nl/onze-mensen

Outra aba do site é a de oferta de empregos. Mas não é apenas uma chamada. Cada atividade é apresentada como agregado de valor de suas funções, com pequenos vídeos contendo relato de trabalhadores, como se pode conferir em https://careers.renewi.com/nl-nl/werkgebieden/chauffeur-belader. O site anuncia, por exemplo, em relação ao motorista de caminhão de lixo: 
Como motorista, você pode ter a função mais importante no Renewi. Você é o cartão de visita dos clientes e é responsável pela coleta de vários fluxos de resíduos, como papel, papel alumínio, resíduos de construção, documentos confidenciais ou resíduos industriais. Você o leva para um de nossos locais, onde o processamos em matériasprimas secundárias, a partir das quais novos produtos podem ser produzidos. Dessa forma, você contribui para um mundo mais limpo e sustentável. Conosco, você pode contar com: salário sempre pontual, horas extras são pagas, visto do contrato permanente. Você dirige em turnos diurnos e volta para casa a tempo. Independência, variedade e contato com os clientes. Oportunidades de carreira e ótimos colegas. Consulta, setembro, 2019.

A RENEWI afirma desenvolver uma economia inteligente, sustentável e circular, na qual não existe desperdício. Centrada na reciclagem de matérias-primas, garante desenvolver uma política de valorização do ambiente e natureza no combate a emissões de CO2 ao mínimo e ao esgotamento da Terra.

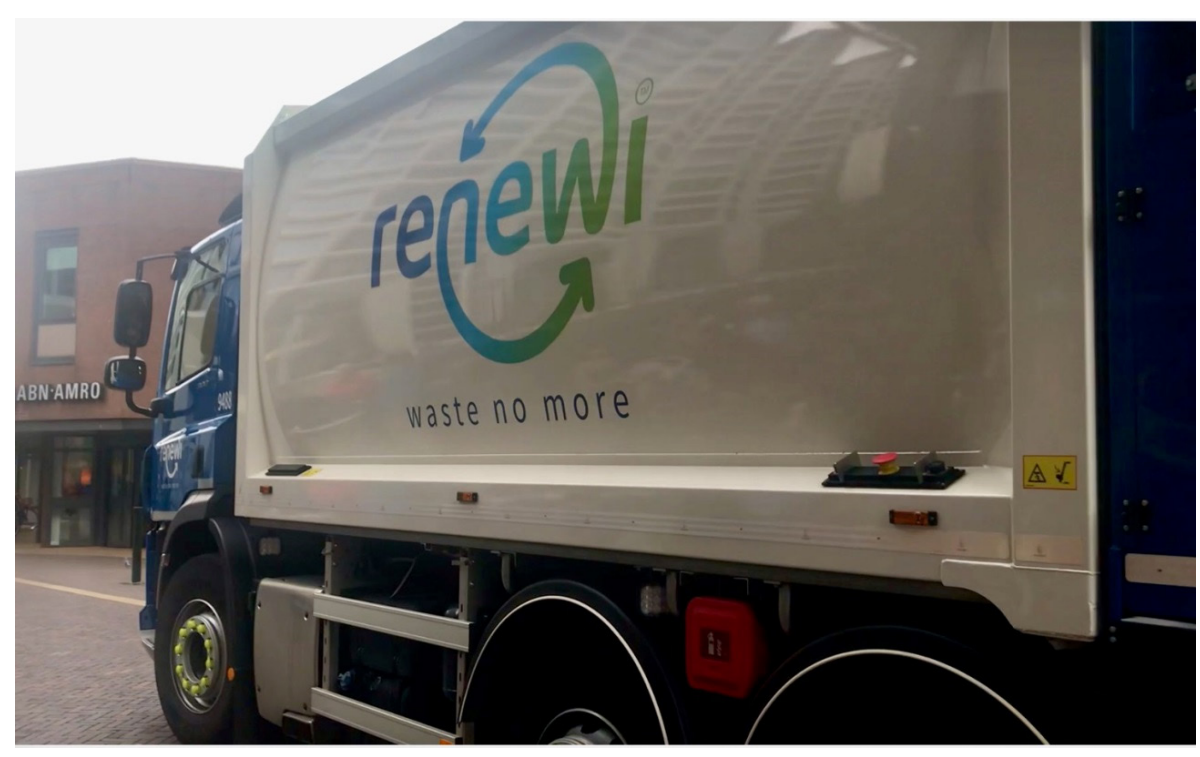

119

119 - Caminhão Renewi. Importante indústria de reciclagem. Foto de Cornelia Eckert. Zaandam, 09 setembro 2019.

\section{As reuniões de intercâmbio}

Nem todo o curto período de pesquisa foi caracterizado por etnografias nas ruas e entrevistas em Zaandam e Amsterdã. Conforme previsto no plano de estágio trabalho, as pesquisadoras participaram de duas reuniões de intercâmbio do projeto Economia circular: antropologias do lixo/resíduos sólidos e experiências inovadoras entre Holanda e Brasil. Nessas reuniões, reforçaram a importância de dar continuidade ao 
Programa CAPES-NUFFIC entre a Universidade Federal de Santa Catarina, Florianópolis (SC), Brasil, e VU University Amsterdam, Holanda. As reuniões ocorreram na Vrije Universiteit Amsterdan, um imenso complexo universitário onde procuramos o Departamento de Antropologia.

Foram recebidas por Freek Colombijn, coordenador do projeto pela Holanda. Nesta ocasião, na condição de coordenadora do projeto pelo lado brasileiro, Carmen apresentou um relato das atividades realizadas durante o período de missão e, em seguida, expôs uma proposta de renovação da cooperação entre Capes e Nuffic.

Em outra ocasião, a visita à Universidade foi dedicada ao desenvolvimento de uma conferência proferida por Carmen Rial para professores e alunos de Antropologia e Sociologia do Instituto.

Outra reunião foi dedicada à montagem de um plano de trabalho para a continuidade do projeto e encaminhamento de sua renovação, junto com a Profa. Barbara Arisi, da Universidade UNILA, em missão na Holanda.

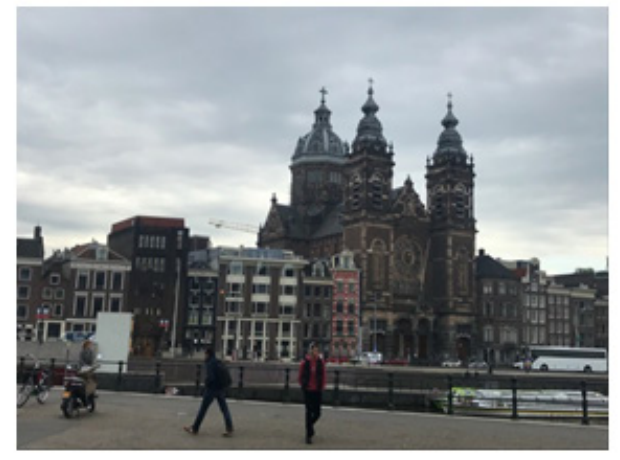

120

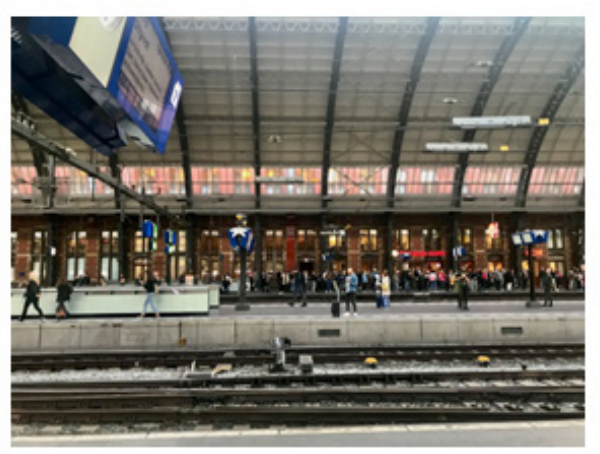

122

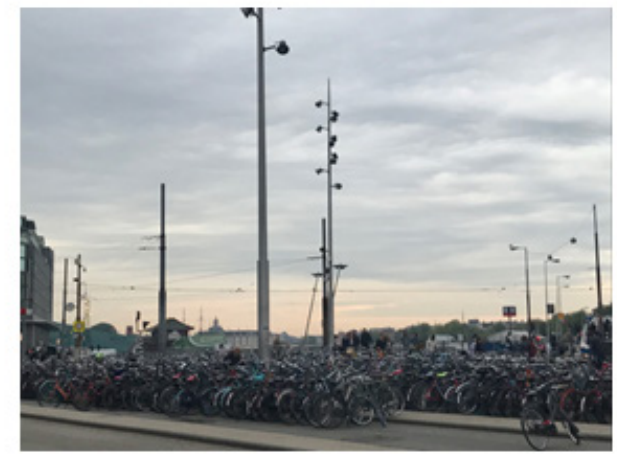

121

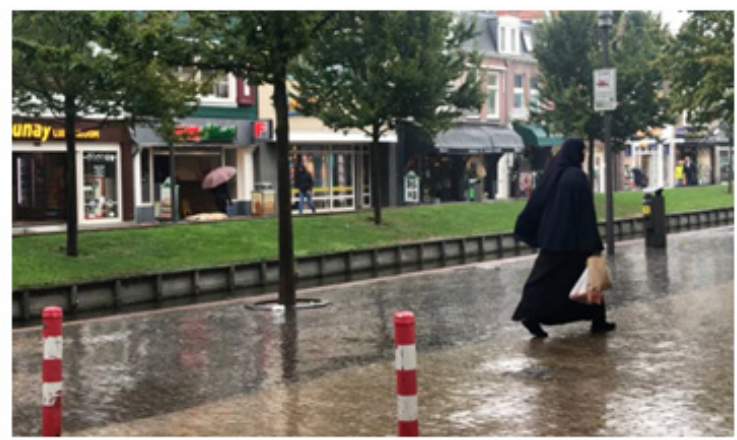

123 


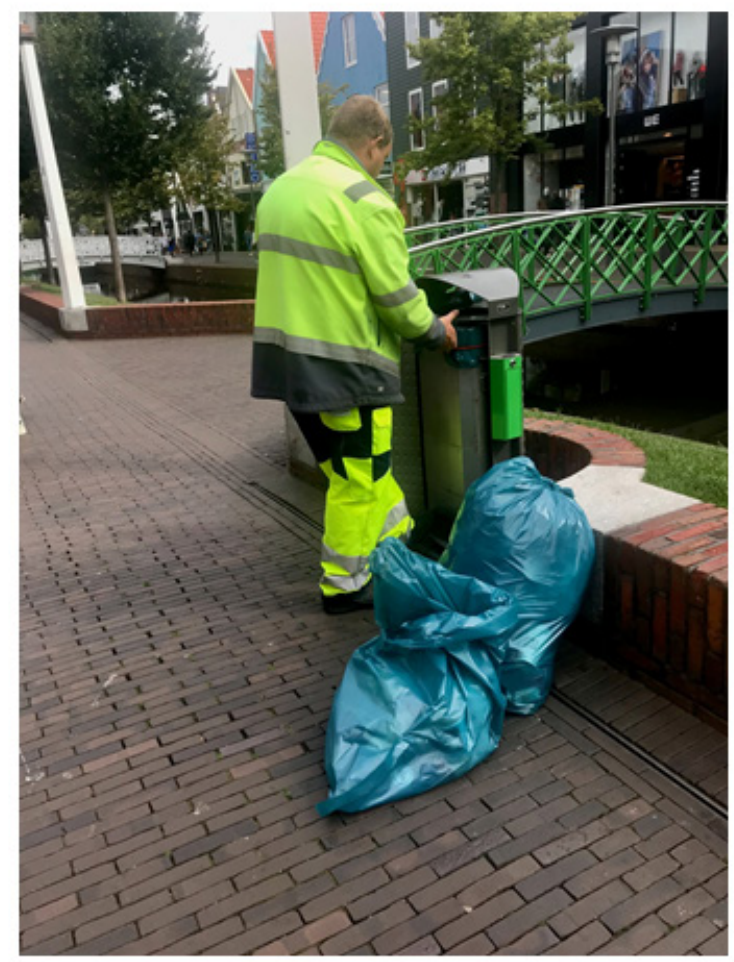

124

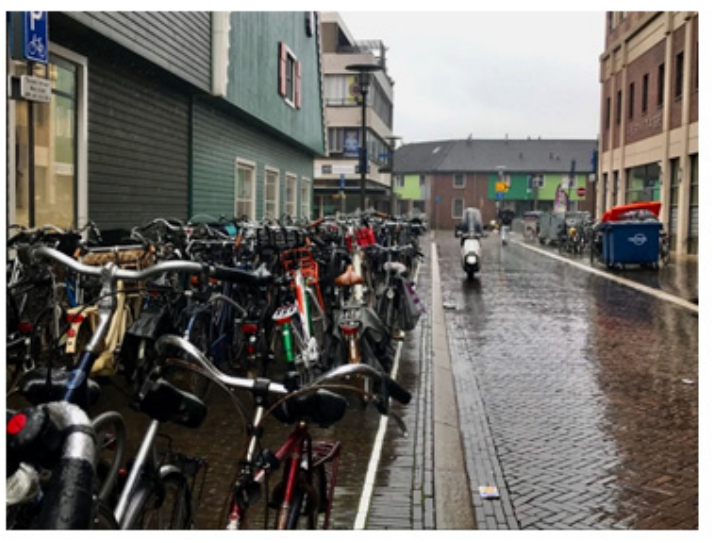

125
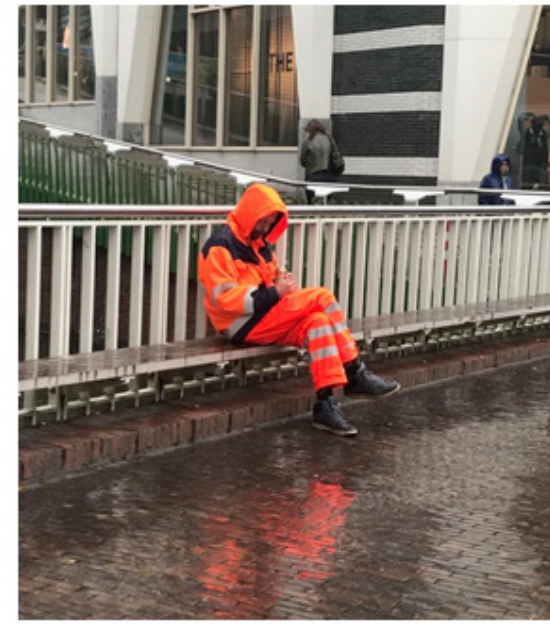

126

120 - Estação ferroviária Amsterdã. Foto de Cornelia Eckert. Zaandam, 10 setembro 2019.

121 - A cidade das bicicletas. Estação ferroviária. Amsterdã. Idem

122 - Estação ferroviária Amsterdã. Idem

123 - Último dia em Zaandam. Muita chuva. Última caminhada de observação e detalhes. Foto de Cornelia Eckert. Zaandam, 11 setembro 2019.

124 - Conversa com o trabalhador. Neste dia não era Spencer. Mandamos abraços. Idem 
125 - Zaandam das bicicletas. Idem

126 - O trabalhador cansado. Idem

\section{Considerações analíticas}

A estada na Holanda, que esse relatório descreve, com a Etnografia de Rua, agregou também informações como a leitura de artigos e matérias jornalísticas, por exemplo. Nestas considerações finais, alguns dos elementos ali captados estão presentes. Gostaríamos de ressaltar dois pontos especialmente: 1. a crise do lixo nos Países Baixos; 2. a visibilidade do lixo.

Com uma entrada tardia na política de reciclagem, visando um desenvolvimento sustentável, o país é hoje um dos mais importantes centros de referência para as políticas de tratamento de resíduos orgânicos e sólidos, mas passa por sérios problemas. A globalização de mercadorias, que durante muito tempo foi o descarte das mesmas, está sendo colocada em xeque por uma nova economia mundial e por uma sensibilidade cada vez mais ecológica na Europa. Assim como as lojas de "preço justo" e os produtos de fair trade se multiplicam nas prateleiras dos supermercados, atraindo consumidores que não se importam de pagar mais pelo café, tendo a garantia de que os camponeses na Costa Rica vão receber mais, assim também está cada vez mais em questão a exportação de resíduos sólidos para países africanos ou asiáticos, economicamente vulneráveis, fato que evidencia a emergência das críticas em relação aos programas neocoloniais que muitos europeus já consideram inaceitáveis.

De outra parte, há mudança nos rumos do lixo produzido nos Países Baixos, que antes se dirigia para a China. Com a enorme ascensão econômica do gigante asiático e com uma certa virada ecológica também na $\mathrm{China}^{8}$, para lá já não se dirige mais. Ora, os Países Baixos têm sérios constrangimentos territoriais. É um país estabelecido, em boa parte, sobre aterros que avançam sobre o mar, mas o espaço é muito limitado. Onde

\footnotetext{
${ }^{8}$ Carmen conversa com um professor chinês que pertence a um centro de migração, e ele diz que a China está começando a fazer a reciclagem. Como se trata de uma política governamental, "as senhoras chinesas" querem ajudar a implementar. Então, elas costumam ficar ao lado da lata do lixo, e quando jovens chegam, elas perguntam: "o que é isso?" Para poder indicar em qual das latas de lixo eles devem depositar aquele lixo. Os jovens chineses fazem piada. Alguns dizem que, se tu comes um peixe, o resto da carne do peixe tem que ir para uma lata, os ossos têm que ir para outra, e assim por diante. Percebe-se com essa anedota que, na China, ao contrário de muitos outros países, a sensibilidade em relação à reciclagem não é alguma coisa que esteja mais forte entre os jovens, provavelmente por ter sido uma política que veio de cima para baixo, como são as políticas na China. Partiu do governo, visto como algo autoritário.
} 
colocar todo o lixo que essa sociedade produz, se não pode ser exportado? A reciclagem, e nela a importante presença da privatização da economia de reciclagem, é uma das respostas possíveis. E quem fala em privatização, fala em busca de rentabilidade. O lixo a ser reciclado implica lucro e economia de gastos com coleta (coletas programadas).

Observa-se o avanço de biopolíticas em que o Estado estabeleceu um projeto de reciclagem controlada, seguida pela sociedade civil para evitar a contravenção, seja por adesão a uma economia verde ou a projetos ecológicos. A consequência dessa mudança no tratamento do lixo - que, embora já existisse antes, reforçou-se enormemente nos últimos 2 anos - é a nova visibilidade que o descarte ganha no cotidiano dos indivíduos. Mesmo em apartamentos pequenos como acontece na grande parte dos espaços domésticos em Amsterdã, cidade com o metro quadrado de alto custo, os recipientes para recolher os resíduos sólidos passam a ocupar boa parte da peça. E a opção por um ou outro implica uma escolha, uma operação racional: 'devo colocar isso aqui ou ali?' Não se pode mais ter o automatismo de outros tempos, em que o pé acionava a tampa da lata de lixo e para lá ia tudo o que já não servisse, num gesto quase inconsciente.

Mesmo quem está de passagem no país, como era o caso das pesquisadoras, sente a mudança da política em torno do lixo que envolve até os hotéis. No banheiro do quarto do seu hotel havia um anúncio dizendo que, em caso de acúmulo, o lixo no quarto poderia ser levado (pelo hóspede, entenda-se) até uma lata um pouco maior que fica no corredor do andar. O lixo perdeu a sua invisibilidade também nesse espaço, pois o que antes era a serviço das camareiras, agora se torna algo que tem de ser feito por todos nós. Outro exemplo de novas normas na compra de eletrodomésticos, além das instruções do caderninho que acompanha tradicionalmente esses produtos, agrega-se agora uma folha separada, dizendo que aquele objeto não pode ser descartado como lixo comum e que deve ser levado a lugares especiais para o seu descarte. Essa informação, que antes aparecia no Manual de Instruções, agora merece um espaço bem maior, bem mais visível.

À visibilidade do lixo agregam-se as penalidades e a vigilância. Os holandeses com quem elas conversaram, em geral, sentem-se vigiados pelo Estado com os seus controles sobre os tipos de lixo, os cartões que individualizam o acesso aos containers e que podem fornecer ao governo, a qualquer momento, dados sobre seu consumo privado - o que não lhes parece preocupar, não havendo ênfase nesse ponto - e dados 
sobre a exatidão do descarte, se fizeram bem ou não a triagem, e isso tem implicações financeiras com multas altas. Fora dos dias e horários previstos para o recolhimento, cabe ao indivíduo buscar outro local para o descarte - o que nem sempre é tarefa simples e pode ter consequências se não o for feito regularmente, novamente com multas monetárias.

A etnografia em Zaandam, que responde às nossas indagações sobre as inovações sociotécnicas (Latour, 2005) nas diversas gerações e à consolidação de indústrias de processamento de materiais recicláveis e de economia circular, mostra que estes avanços ganham proporções rentáveis em torno da gestão do mercado de reciclagem, que corresponde à implantação da agenda marrom (referindo-se, de sua parte, às prioridades e medidas voltadas para evitar, reduzir ou controlar atividades poluidoras) que regulariza a proteção ambiental. A pesquisa etnográfica e de acervo em Zaandam, somada às entrevistas realizadas, revelaram que estas práticas de separação do lixo, coleta de resíduos, reaproveitamento do lixo orgânico e reciclagem do inorgânico são diferenciadas nas experiências geracionais relacionadas às histórias de suas territorialidades, como a de Zaandam. Surpreendeu-lhes encontrar uma política de controle tão recente e com funcionamento na perspectiva punitiva para a consistência de uma política ecológica.

Mas a etnografia sempre permite reconhecer os fluxos da vida cotidiana e, no caso da experiência delas em Zaandam, como o tema do lixo é vivenciado como política ecológica, não sem conflitos e contradições, coloca sempre em pauta a pergunta: o que fazer com tanto lixo em um planeta que se mostra cada vez mais esgotado?

\section{REFERÊNCIAS}

ECKERT, C.; ROCHA, A. L. C. Antropologia da memória de bairros de vocação industrial em crise. In: URIARTE, Urpi Montoya e MACIEL, Maria Eunice. (Org.). Patrimônio, cidades e memória social. 1ed. Salvador, EDUFBA; ABA, 2016, v. 1, p. 95-122.

ECKERT, Cornelia et ali. Cartas aos Narradores urbanos, Etnografia de Rua na Porto Alegre das Intervenções Artísticas. 1. ed. Porto Alegre, UFRGS, 2018. v. 1. 136 p. 
HOEVEN, VITTORIA VAN DER. Constructing a Sustainable Community: The story of De Ceuvel de Vittoria van der Hoeven. Master. Orientação Freek Colombijn (VU Amsterdam). 2019.

LATOUR, Bruno. Reassembling the Social, an introduction to Actor-Network-Theory. Oxford, Oxford University Press, 2005.

RIAL, Carmen et alli. O Poder do Lixo: Abordagens antropológicas dos resíduos sólidos. Rio de Janeiro, ABA, 2016.

ROCHA, Carla Pires Vieira da. Comida em uma cidade global: práticas alimentares de imigrantes transnacionais em Amsterdã. Doutorado em Interdisciplinar em Ciências Humanas 2013 - 2017. Universidade Federal de Santa Catarina. Orientadora Dra. Carmen Sílvia de Moraes Rial. Coorientador: Marcos Fábio Freire Montysuma. Bolsista do(a): Coordenação de Aperfeiçoamento de Pessoal de Nível Superior, CAPES, Brasil. 2017.

ROCHA, Ana Luiza; ECKERT, Cornelia. A preeminência da imagem e do imaginário nos jogos da memória coletiva em coleções etnográficas. Brasília: ABA, 2016.

Recebido: $08 / 11 / 2020$

Aprovado: $08 / 12 / 2020$ 